LA-12951-PR

Progress Report
Water Supply at

Los Alamos during 1993

\title{
Main Aquifer Test Wells
}

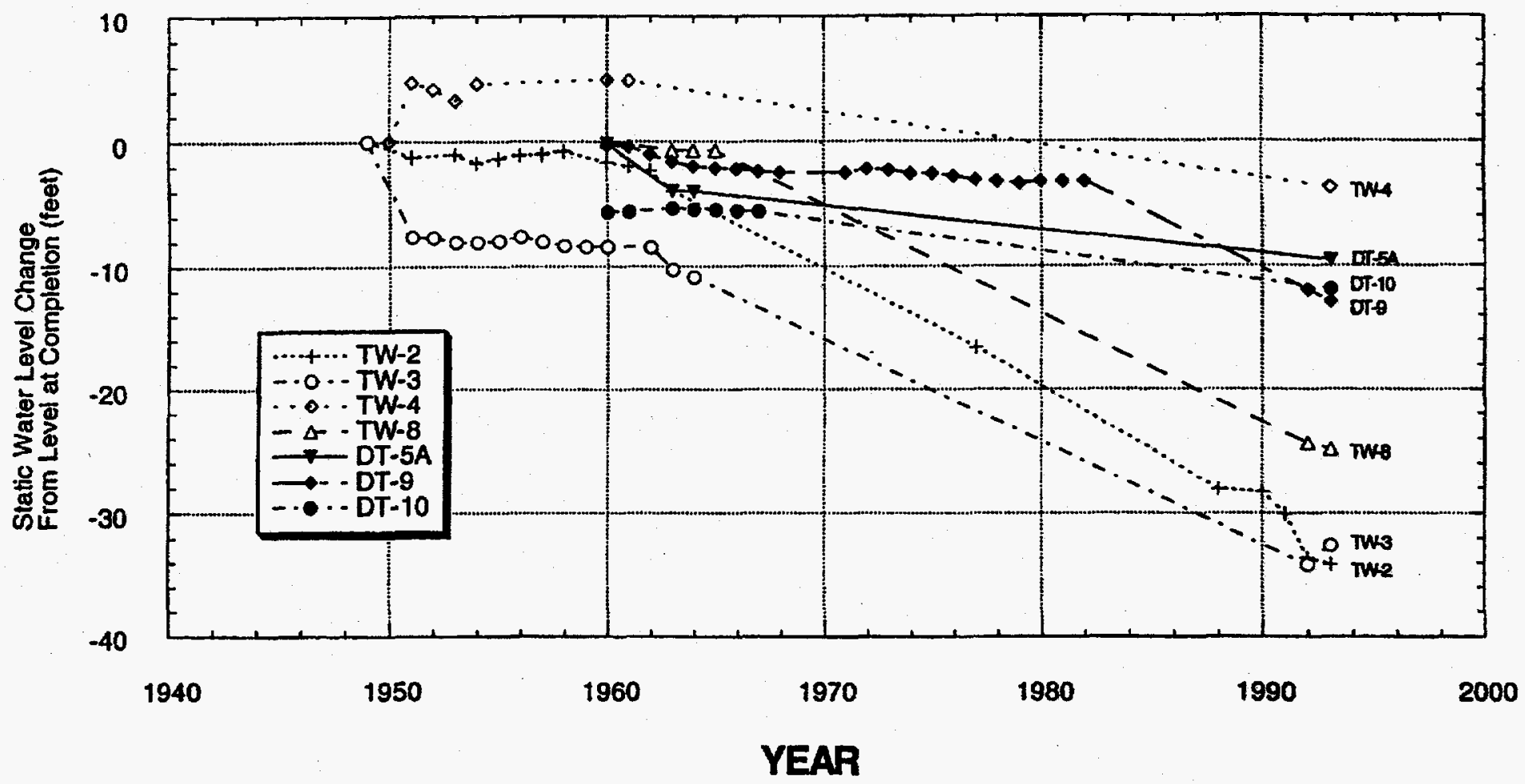


The four most recent reports in this series, unclassified, are LA-12276-PR, LA-12471-PR, LA-12770-PR, and LA-12926-PR.

Prepared by Belinda Gutierrez, Group ESH-20

Cover illustration: The graph illustrates the changes in water levels observed in the test wells in the main aquifer of the Los Alamos area. These changes indicate declines of as much as 35 feet. Water level changes in pumping well fields are discussed in Section $V$ of this report.

An Affirmative Action/Equal Opportunity Employer

This report was prepared as an account of work sponsored by an agency of the United States Government. Neither The Regents of the University of California, the United States Government nor any agency thereof, nor any of their employees, makes any warranty, express or implied, or assumes any legal liability or responsibility for the accuracy, completeness, or usefulness of any information, apparatus, product, or process disclosed, or represents that its use would not infringe privately owned rights. Reference herein to any specific commercial product, process, or service by trade name, trademark, manufacturer, or otherwise, does not necessarily constitute or imply its endorsement, recommendation, or favoring by The Regents of the University of California, the United States Government, or any agency thereof. The views and opinions of authors expressed herein do not necessarily state or reflect those of The Regents of the University of California, the United States Government, or any agency thereof. 
Water Supply at

Los Alamos during 1993

W. D. Purtymun

A. K. Stoker

S. G. McLin

M. N. Maes

T. A. Glasco 



\section{DISCLAIMER}

Portions of this document may be illegible in electronic image products. Images are produced from the best available original document. 


\section{CONTENTS}

FIGURES ..vi

TABLES

ABSTRACT 1

I. INTRODUCTION 1

II. WELL FIELD CHARACTERISTICS......................................................

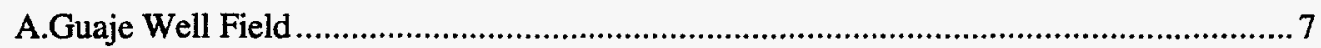

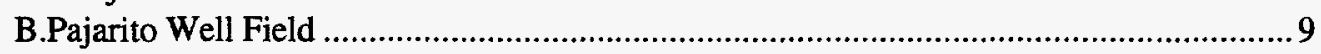

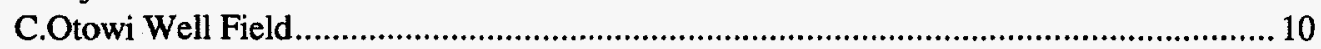

III. WATER CANYON GALLERY AND GUAJE AND LOS ALAMOS RESERVOIRS.

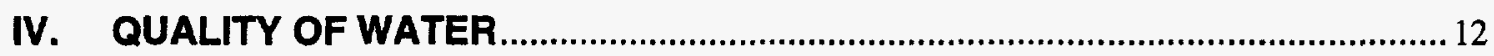

V. LONG-TERM WATER LEVEL TRENDS .................................................... 12

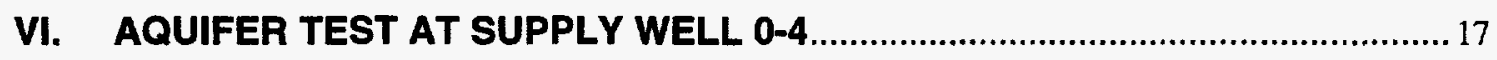

VII. PLUGGING OF LOS ALAMOS WELLS LA-1, LA-3, LA-4, AND LA-6.

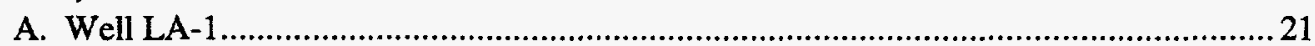

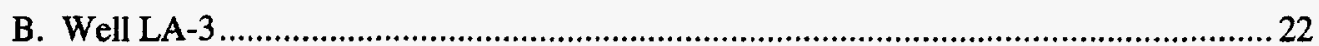

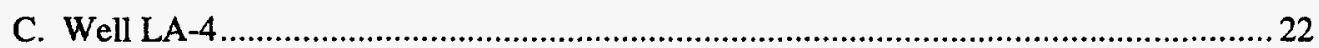

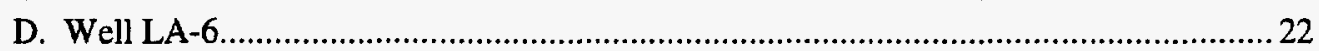

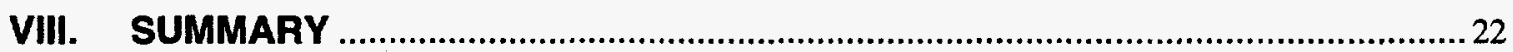

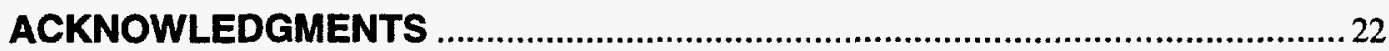

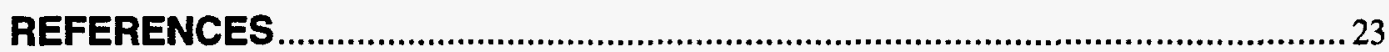

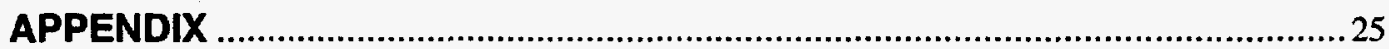




\section{FIGURES}

1. Locations of reservoirs, well fields, water supply wells, and gallery water supply

2. Water production and usage from 1947 to 1993, and projected demands. ................................6

3. Nonpumping water levels in wells in the Guaje Well Field............................................... 10

4. Nonpumping water levels in wells in the Pajarito Well Field. .............................................. 11

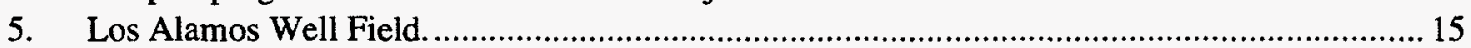

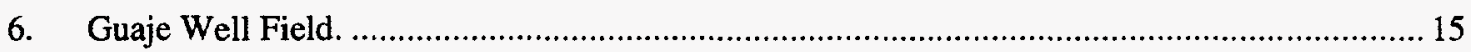

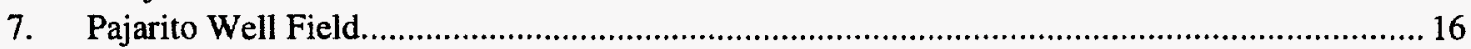

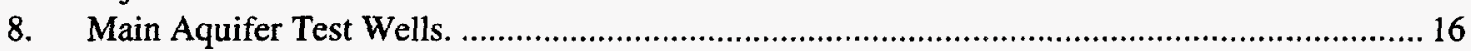

9. Generalized water level contours at Los Alamos, prepumping and 1993 ............................... 18

10. Pump test analysis at Well Otowi-4: a, discharge history in Otowi-4; and $\mathrm{b}$, drawdown response in Test Well TW-3, located $413 \mathrm{ft}$ away, from February 24 to March 18, 1993

11. The Cooper-Jacob method analysis of drawdown data from Well Otowi-4.

\section{TABLES}

1. Production of Potable Water from Wells and Gallery, 1947-1993 ........................................4

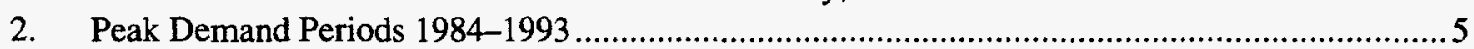

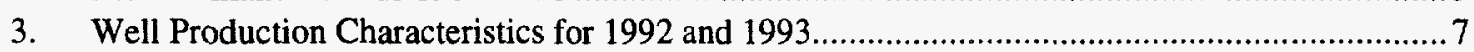

4. Average Pumping Rate and Specific Capacity, 1992 and 1993 ............................................8

5. Average Water Levels for Nonpumping and Pumping Wells and

Average Drawdown, 1992 and 1993

6. Production from Water Canyon Gallery and Guaje and Los Alamos Reservoirs........................ 13 


\section{APPENDIX TABLES}

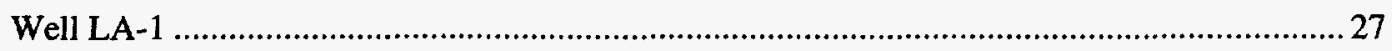

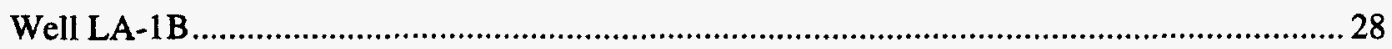

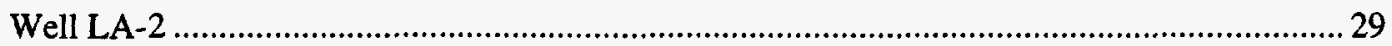

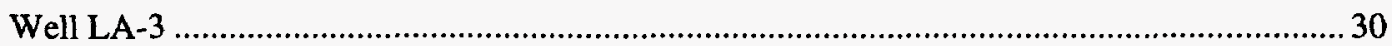

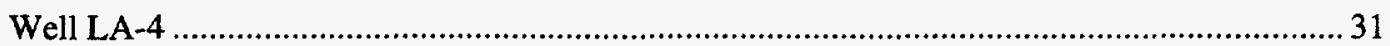

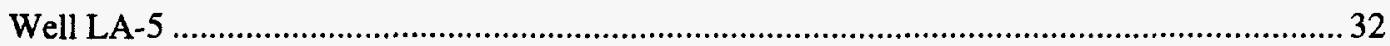

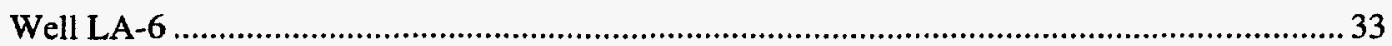

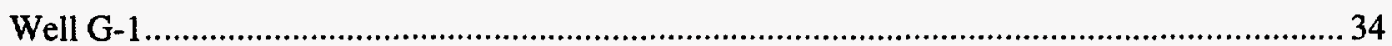

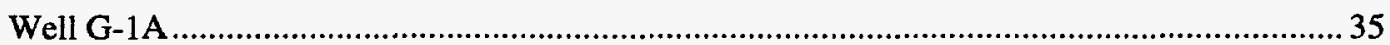

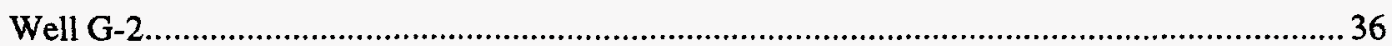

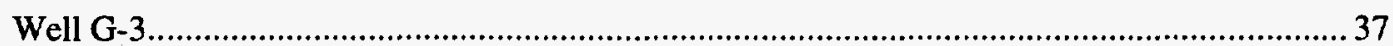

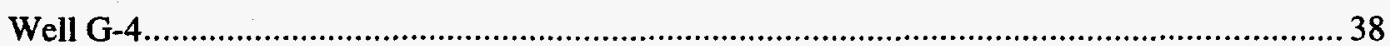

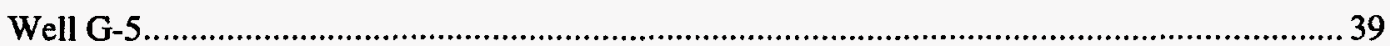

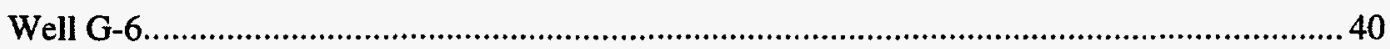

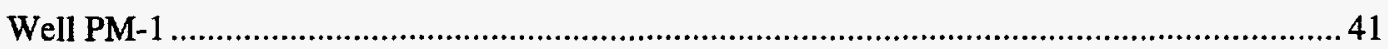

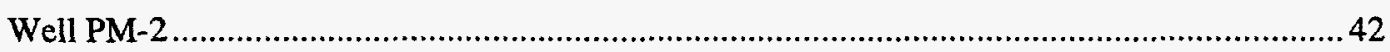

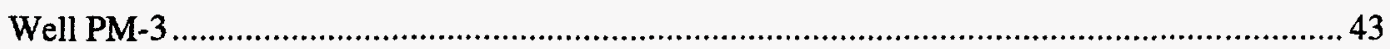

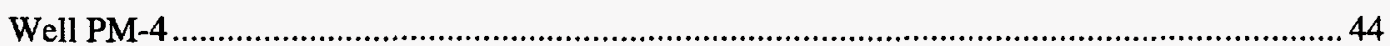

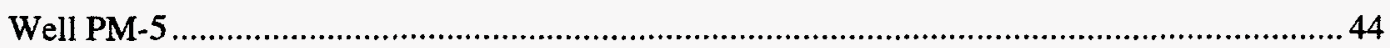

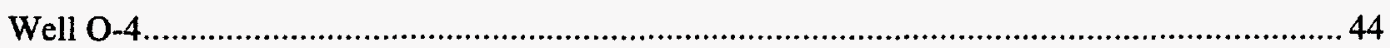

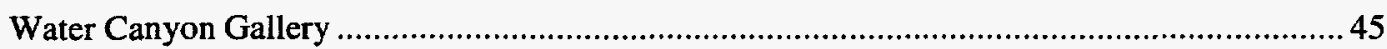

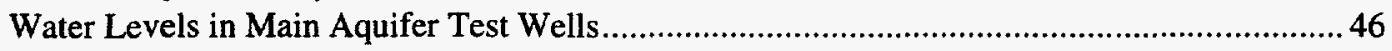




\title{
WATER SUPPLY AT LOS ALAMOS DURING 1993
}

by

W. D. Purtymun, A. K. Stoker, S. G. McLin, M. N. Maes, and T. A. Glasco

\begin{abstract}
Municipal potable water supply during 1993 was about $1,457 \times 10^{6}$ gal. from wells in the Guaje, Pajarito, and Otowi Well Fields. The nonpotable water supply used for industry was about $6.4 \times 10^{6} \mathrm{gal}$. from the spring gallery in Water Canyon. Nonpotable water used for irrigation from Los Alamos Reservoir was about $0.5 \times 10^{6}$ gal; thus, the total water usage in 1993 was about $1,464 \times 10^{6} \mathrm{gal}$. One of the two wells in the Otowi Well Field, Well O-4, was operational in 1993. It produced about $284 \times 10^{6} \mathrm{gal}$, or about $19 \%$ of the total production from the two well fields. Wells in the Los Alamos Field, on Pueblo land, were transferred to San Ildefonso Pueblo in 1992. With concurrence with the Pueblo, four of the wells were plugged in 1993.
\end{abstract}

\section{INTRODUCTION}

This report summarizes production and aquifer conditions for water wells in the Guaje, Pajarito, and Otowi Well Fields (Figure 1). These wells supplied all of the potable water used for municipal and some industrial purposes in Los Alamos County and the Los Alamos National Laboratory during 1993. The wells in the Los Alamos Well Field were transferred to San Ildefonso Pueblo in 1992. Four of the wells in the Los Alamos Well Field were plugged in 1993. One of the two new wells in the Otowi Well Field became operational in 1993. The spring gallery in Water Canyon supplied nonpotable water for industrial use, while surface water from the Los Alamos Reservoir was diverted for irrigation. In 1993 no water was used from the Guaje Reservoir. Due to the maintenance and operating cost of diverting water from the reservoirs, it is not economically feasible to continue their use for irrigation.

This report fulfills some of the requirements of the Los Alamos Groundwater Protection Management Program by documenting use of the groundwater for water supply and providing information on hydrologic characteristics of the main aquifer. This report is a joint effort between the Laboratory Water Quality and Hydrology Group and the Utilities Department of Johnson Controls World Services Inc. (JCI). The purpose of this report is to ensure a continuing historical record and to provide guidance for management of water resources in long-range planning for the water supply system. We have issued one summary report for the period of 1947 to 1971 and 22 annual reports that contain the results of our studies of these water supplies.1-23 An additional report summarized the hydrology of the main aquifer with reference to future development of groundwater supplies. ${ }^{24}$ A report was issued in 1988 that examined the status of wells and future water supply. ${ }^{25}$

JCI, the support contractor to the Laboratory and the Department of Energy (DOE) at Los Alamos, maintains and operates the water supply system. Water from the system is sold to the county for the communities of Los Alamos and White Rock and to the National Park Service for the water supply at Bandelier National Monument.

After the potable water is pumped from the wells into the distribution lines, it is lifted by booster pumps into reservoirs (tanks) for storage and distribution to the Laboratory and the community. The entire water supply is disinfected before being distributed to Los Alamos, White Rock, Bandelier National Monument, 


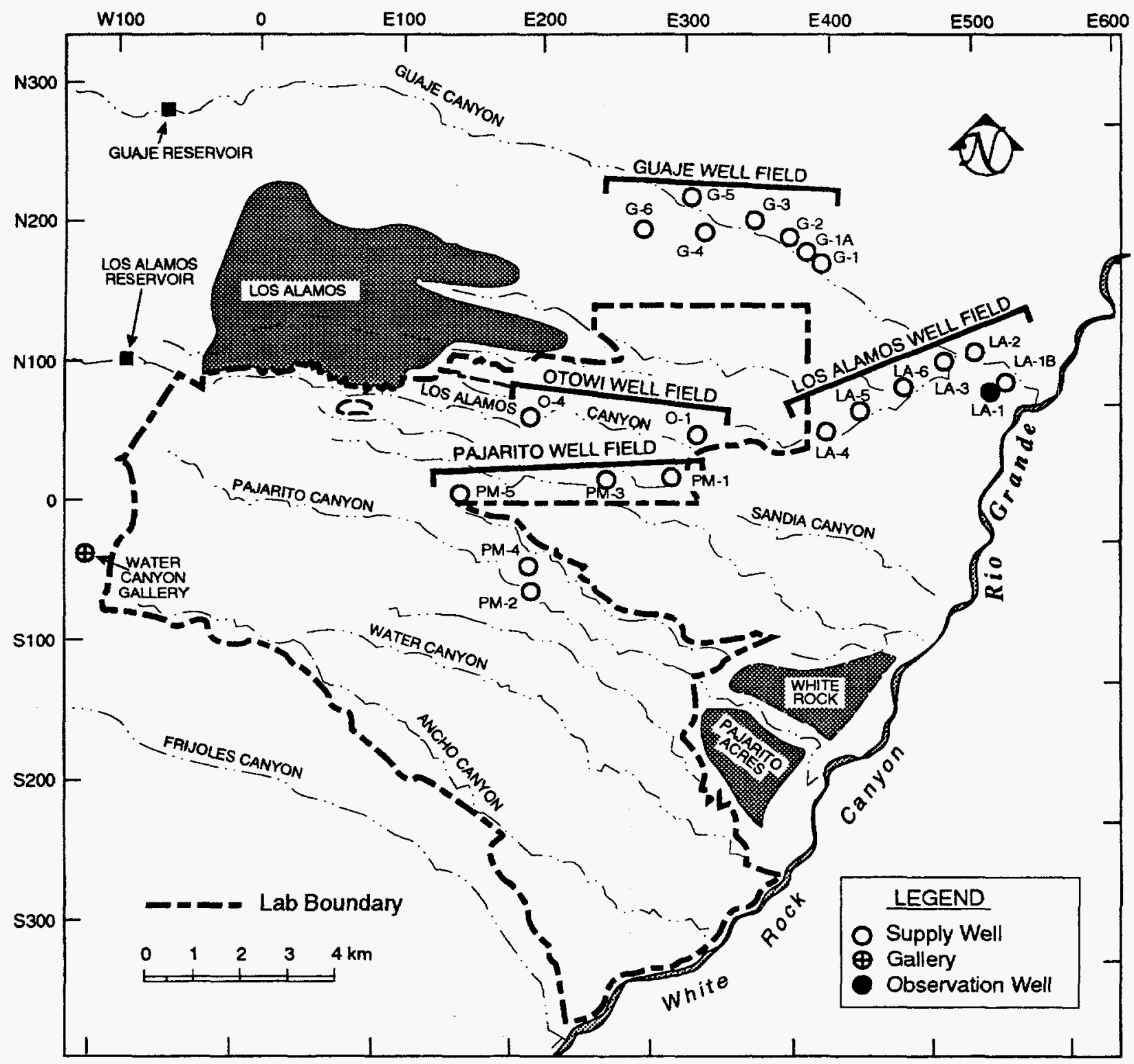

Figure 1. Locations of reservoirs, well fields, water supply wells, and gallery water supply. Letter designations on the figure indicate wells in the Guaje (G), Pajarito (PM), Los Alamos (LA), and Otowi $(\mathrm{O})$ Well Fields. 
and Laboratory areas (Figure 1). The nonpotable water used for industrial use at TA-16 flows by gravity from the gallery in Water Canyon to the steam plant. The transmission line from the gallery to the steam plant is separate from that of the potable supply.

JCI maintains a record of the hours of operation for each well along with records of daily and monthly water production. The monthly averages of nonpumping and pumping water levels are computed from air line pressure or transducer data recorded at each well. These data are used in calculating the pumping rates, drawdown, and other well field statistics that are included in this report. The Appendix contains annual pumping and production information for each water supply well for the period of record.

Water for the Laboratory, the communities of Los Alamos and White Rock, and Bandelier National Monument for 1993 was supplied from three well fields. Production was from nine wells, three of the seven wells in the Guaje Field, all of the five wells in the Pajarito Field, and one of the two wells in the Otowi Field. The well fields are located on the Pajarito Plateau and in Guaje Canyon (Figure 1). The wells are completed in the main aquifer of the Los Alamos area, the only aquifer capable of municipal and industrial water supply. The piezometric, or pressure, surface of the main aquifer ranges from near ground level (artesian) in the old well field in lower Los Alamos Canyon to about $760 \mathrm{ft}$ along the eastern edge of the plateau to more than 1,200 ft near the center of the plateau at Well PM-5. Water in the aquifer moves eastward beneath the plateau to the Rio Grande, where some water is discharged into the river through seeps and springs. ${ }^{24}$

The Water Canyon Gallery, which is located west of the Laboratory on the flanks of the Sierra de los Valles, discharges water from a small aquifer perched in the volcanic rocks (Figure 1). The two reservoirs, Guaje and Los Alamos, are located on the flanks of the Sierra de los Valles to the northwest and west of Los Alamos (Figure 1).

\section{WELL FIELD CHARACTERISTICS}

Production from the three well fields decreased about $72 \times 10^{6}$ gal., from $1,529 \times 10^{6}$ gal. in 1992 to about 1,457 $\times 10^{6}$ gal. in 1993 (Table 1). The months of heaviest production in 1993 were June, July, and August. The production during these months was $546 \times 10^{6}$ gal., an increase of $35 \times 10^{6}$ gal. from a similar period of heavy production in 1992. The months of lightest production were February, March, and December with a production of $229 \times 10^{6}$ gal., a decrease of $31 \times 10^{6}$ gal. from a similar period in 1992 .

The difference in demand between periods of heavy and light production (i.e., summer and winter demands) occurs mainly because of water usage for landscape irrigation. The water levels in the wells respond accordingly, with the highest water levels observed during months of least production and the lowest water levels occurring during months of greatest production. The growing season which requires irrigation occurs from April through September. About $64 \%\left(937 \times 10^{6}\right.$ gal.) of the total water used $\left(1,457 \times 10^{6}\right.$ gal. $)$ occurred during this time. The annual and monthly variation in water usage cannot be correlated with annual or monthly precipitation.

The peak demand periods occur in the summer and for the past 10 years (1984-1993) have ranged from 6 to 34 days (Table 2). The average daily production has ranged from $6.5 \times 10^{6}$ gal. per day (gpd) to $9 \times$ $10^{6} \mathrm{gpd}$. The peak demand period for 1993 was for 18 days, June 25 through July 12, a total production of $146 \times 10^{6}$ gal. (Table 2). The demand period in 1993 was longer than that in 1992 and required about slightly less than $8.1 \times 10^{6}$ gpd compared with $8.2 \times 10^{6}$ gal. in 1992 .

The production and use of water at the Laboratory and in the community increased from about $230 \times$ $10^{6} \mathrm{gal}$. in 1947 to $1,730 \times 10^{6} \mathrm{gal}$. in 1976 . Water usage in $1977 \mathrm{declined}$ to about $1,500 \times 10^{6} \mathrm{gal}$. and has ranged from about $1,450 \times 10^{6}$ gal. in 1979 to about $1,686 \times 10^{6}$ gal. in 1989 (Figure 2). The 1976 maximum has not been approached in recent years.

The change that occurred in the long-term use pattern is partly attributable to a decline in per capita use by Los Alamos County. The per capita use has declined to about $50 \times 10^{3}$ gal. per year since 1980 , after 
Table 1. Production of Potable Water from Wells and Gallery, 1947-1993 (in millions of gallons)

\begin{tabular}{|c|c|c|c|c|c|c|}
\hline Year & $\begin{array}{l}\text { Los Alamos } \\
\text { Field }\end{array}$ & $\begin{array}{l}\text { Guaje } \\
\text { Field }\end{array}$ & $\begin{array}{l}\text { Pajarito } \\
\text { Field }\end{array}$ & $\begin{array}{l}\text { Otowi } \\
\text { Field }\end{array}$ & $\begin{array}{c}\text { Water Canyon } \\
\text { Gallery }\end{array}$ & $\begin{array}{c}\text { Production } \\
\text { Total }\end{array}$ \\
\hline 1947 & 147 & 0 & 0 & - & 84 & 231 \\
\hline 1948 & 264 & 0 & 0 & - & 97 & 361 \\
\hline 1949 & 302 & 0 & 0 & - & 92 & 394 \\
\hline 1950 & 547 & 3 & 0 & - & 54 & 604 \\
\hline 1951 & 702 & 68 & 0 & - & 39 & 809 \\
\hline 1952 & 448 & 350 & 0 & - & 48 & 846 \\
\hline 1953 & 444 & 372 & 0 & - & 39 & 855 \\
\hline 1954 & 380 & 374 & 0 & - & 40 & 794 \\
\hline 1955 & 407 & 375 & 0 & - & 33 & 815 \\
\hline 1956 & 437 & 506 & 0 & - & 23 & 966 \\
\hline 1957 & 350 & 378 & 0 & - & 40 & 768 \\
\hline 1958 & 372 & 395 & 0 & - & 60 & 827 \\
\hline 1959 & 391 & 478 & 0 & - & 54 & 923 \\
\hline 1960 & 530 & 533 & 0 & - & 48 & 1,111 \\
\hline 1961 & 546 & 624 & 0 & - & 54 & 1,224 \\
\hline 1962 & 577 & 597 & 0 & - & 67 & 1,241 \\
\hline 1963 & 539 & 654 & 0 & - & 51 & 1,244 \\
\hline 1964 & 627 & 665 & 0 & - & 45 & 1,337 \\
\hline 1965 & 447 & 571 & 99 & - & 72 & 1,189 \\
\hline 1966 & 450 & 613 & 127 & - & 82 & 1,272 \\
\hline 1967 & 373 & 464 & 481 & - & 56 & 1,374 \\
\hline 1968 & 345 & 474 & 584 & - & 65 & 1,468 \\
\hline 1969 & 331 & 435 & 569 & - & 80 & 1,415 \\
\hline 1970 & 360 & 423 & 595 & - & 65 & 1,443 \\
\hline 1971 & 412 & 484 & 657 & - & 37 & 1,590 \\
\hline 1972 & 380 & 467 & 662 & - & 40 & 1,549 \\
\hline 1973 & 406 & 475 & 685 & - & 49 & 1,615 \\
\hline 1974 & 369 & 453 & 802 & - & 35 & 1,659 \\
\hline 1975 & 356 & 431 & 749 & - & 42 & 1,578 \\
\hline 1976 & 343 & 531 & 817 & - & 41 & 1,732 \\
\hline 1977 & 345 & 515 & 614 & - & 57 & 1,531 \\
\hline 1978 & 302 & 444 & 690 & - & 45 & 1,481 \\
\hline 1979 & 289 & 456 & 662 & - & 44 & 1,451 \\
\hline 1980 & 339 & 485 & 743 & - & 32 & 1,599 \\
\hline 1981 & 336 & 469 & 701 & - & 45 & 1,551 \\
\hline 1982 & 317 & 422 & 773 & - & 46 & 1,558 \\
\hline 1983 & 221 & 338 & 904 & - & 38 & 1,501 \\
\hline 1984 & 326 & 460 & 780 & - & 34 & 1,600 \\
\hline 1985 & 290 & 456 & 841 & - & 37 & 1,624 \\
\hline 1986 & 179 & 460 & 858 & - & 28 & 1,525 \\
\hline 1987 & 217 & 485 & 892 & - & 34 & 1,628 \\
\hline 1988 & 158 & 477 & 824 & - & $-^{a}$ & 1,459 \\
\hline 1989 & 219 & 506 & 961 & - & $-^{a}$ & 1,686 \\
\hline 1990 & 187 & 532 & 923 & - & $-^{a}$ & 1,642 \\
\hline 1991 & 125 & 502 & 820 & - & $-^{a}$ & 1,447 \\
\hline 1992 & 13 & 472 & 1,044 & - & $-^{a}$ & 1,529 \\
\hline 1993 & - & 298 & 876 & 284 & $-^{a}$ & 1,458 \\
\hline Total & 16,445 & 19,970 & 20,733 & 284 & 2,129 & 59,561 \\
\hline
\end{tabular}

${ }^{a}$ Water Canyon Gallery is no longer a potable water supply (see nonpotable production, Table 6). 
Table 2. Peak Demand Periods 1984-1993

\section{Demand Period}

\begin{tabular}{|c|c|c|c|c|c|c|c|c|c|c|}
\hline & $\begin{array}{c}\text { June 8- } \\
\text { June } 18 \\
1984 \\
\end{array}$ & $\begin{array}{c}\text { June 29- } \\
\text { July } 16 \\
1985\end{array}$ & $\begin{array}{c}\text { July 28- } \\
\text { August } 10 \\
1986\end{array}$ & $\begin{array}{c}\text { July 2- } \\
\text { July } 17 \\
1987\end{array}$ & $\begin{array}{c}\text { June 18- } \\
\text { June 26 } \\
1988 \\
\end{array}$ & $\begin{array}{c}\text { June 18- } \\
\text { July } 11 \\
1989 \\
\end{array}$ & $\begin{array}{c}\text { May 31- } \\
\text { July } 3 \\
1990 \\
\end{array}$ & $\begin{array}{c}\text { June 24- } \\
\text { June } 29 \\
1991 \\
\end{array}$ & $\begin{array}{c}\text { July 1- } \\
\text { July } 9 \\
1992\end{array}$ & $\begin{array}{c}\text { June 25- } \\
\text { July } 12 \\
1993 \\
\end{array}$ \\
\hline No. of days & 11 & 18 & 14 & 16 & 9 & 24 & 34 & 6 & 9 & 18 \\
\hline Total production (gal.) & $81 \times 10^{6}$ & $138 \times 10^{6}$ & $91 \times 10^{6}$ & $134 \times 10^{6}$ & $63 \times 10^{6}$ & $216 \times 10^{6}$ & $297 \times 10^{6}$ & $45.8 \times 10^{6}$ & $73.9 \times 10^{6}$ & $145 \times 10^{6}$ \\
\hline $\begin{array}{l}\text { Average daily } \\
\text { production (gal.) }\end{array}$ & $7.4 \times 10^{6}$ & $7.7 \times 10^{6}$ & $6.5 \times 10^{6}$ & $8.4 \times 10^{6}$ & $7.0 \times 10^{6}$ & $9.0 \times 10^{6}$ & $8.7 \times 10^{6}$ & $7.6 \times 10^{6}$ & $8.2 \times 10^{6}$ & $8.1 \times 10^{6}$ \\
\hline No. of days & & & & & & & & & & \\
\hline$>10 \times 10^{6}$ gal. & - & - & - & 一 & - & 4 & 8 & - & - & - \\
\hline$>9 \times 10^{6} \mathrm{gal}$ & - & 3 & - & 4 & - & 9 & 13 & - & 2 & 2 \\
\hline$>8 \times 10^{6} \mathrm{gal}$ & 2 & 4 & 2 & 7 & 2 & 10 & 3 & 4 & 3 & 12 \\
\hline$>7 \times 10^{6} \mathrm{gal}$ & 6 & 9 & 2 & 4 & 3 & 0 & 4 & - & 4 & 2 \\
\hline$<7 \times 10^{6} \mathrm{gal}$. & 3 & 2 & 10 & 1 & 4 & 1 & 6 & 2 & - & 2 \\
\hline
\end{tabular}


reaching a peak of about $74 \times 10^{3}$ gal. per year in 1974 . Some of this decline may be related to the cost of water, which increased by a factor of about 10 in the last 20 years. Laboratory use has been nearly constant at about $500 \times 10^{6}$ per year since the late $1970 \mathrm{~s}^{23}$

A projection of the total use is plotted along with actual production (Figure 2). The projection is the extrapolation of a least-squares line based on the actual production during the 15-year period 1979 through 1993. The trend line shows a slight decline of about $1.5 \times 10^{6}$ gal. per year.

Annual production is plotted for the Los Alamos, Guaje, Pajarito, and Otowi Well Fields to show a comparison of the distribution of production (Figure 2). The production from any individual well field peaks as another well field is brought on line. The production from the Los Alamos Well Field peaked in 1951 as the Guaje Well Field became operational. Similarly, the production from the Guaje Well Field peaked in 1964 as the Pajarito Well Field was phased into use. The last year of municipal supply from the Los Alamos Well Field occurred in 1991. As a result, the loss of production from the Los Alamos Field was made up by increased production from the Pajarito Well Field. With the first year of operation of the Otowi Well Field in 1993, production from the Pajarito Well Field may have peaked in 1992. The expansion of well fields is necessary as older wells deteriorate with age and the production decreases. New wells must be added to the system to keep up with demand.

The present yield reflects the distribution of production with the addition of the high yield well in the Otowi Well Field; about 20\% from the Guaje Well Field, about 60\% from the Pajarito Field, and about 19\% from the Otowi Well Field. In 1992 the percentage of production was $29 \%$ from the Guaje Well Field and $71 \%$ from the Pajarito Well Field (Table 3).

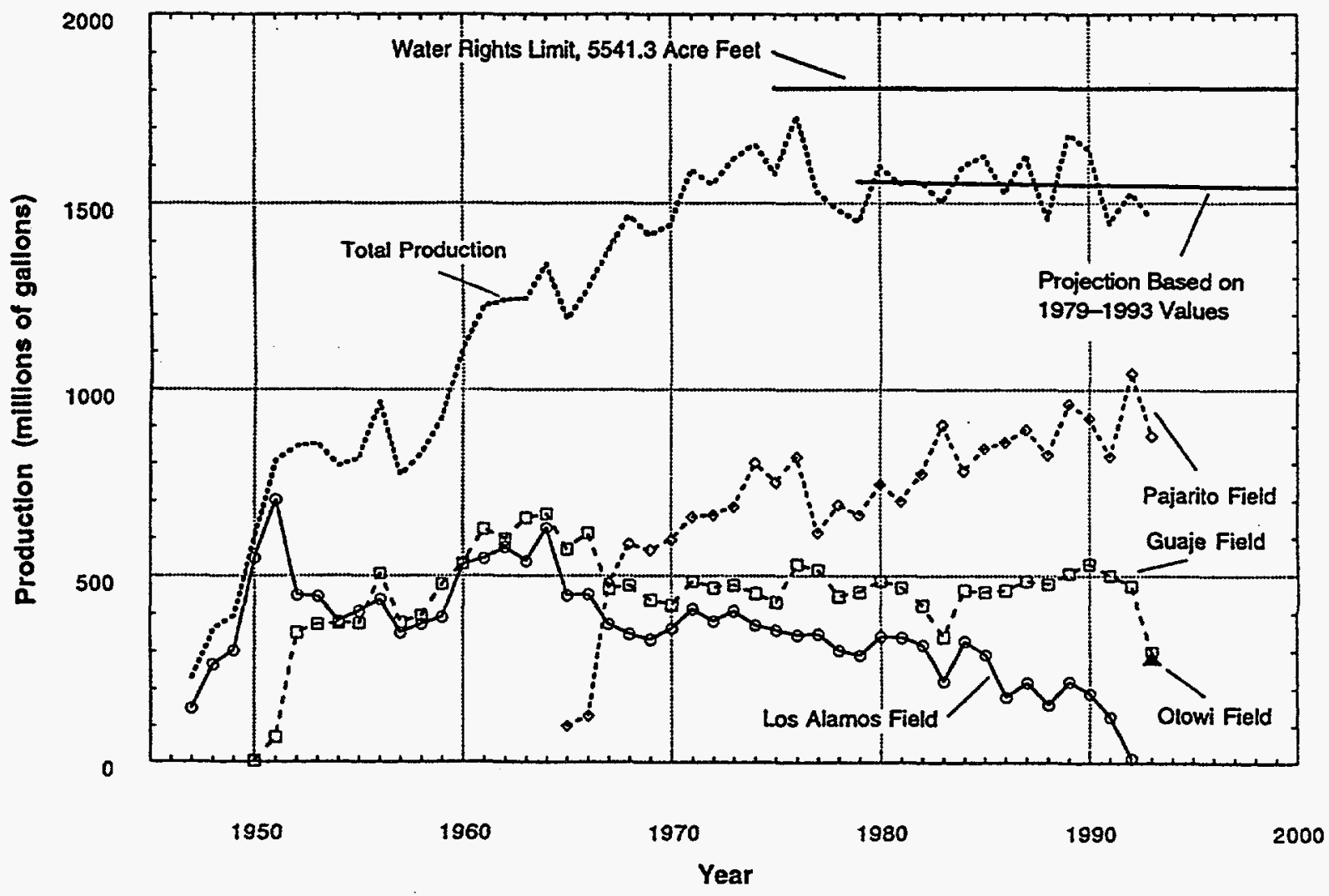

Figure 2. Water production and usage from 1947 to 1993, and projected demands. 
Table 3. Well Production Characteristics for 1992 and 1993

\begin{tabular}{|c|c|c|c|c|c|c|}
\hline & \multicolumn{4}{|c|}{ Production } & \multirow{2}{*}{\multicolumn{2}{|c|}{$\begin{array}{l}\text { Total Production } \\
(\%)\end{array}$}} \\
\hline & \multicolumn{2}{|c|}{$\begin{array}{l}\text { Amount } \\
\left(10^{6} \text { gal. }\right)\end{array}$} & \multicolumn{2}{|c|}{$\begin{array}{l}\text { Well Field } \\
(\%)\end{array}$} & & \\
\hline & $\overline{1992}$ & 1993 & $\overline{1992}$ & 1993 & $\overline{1992}$ & 1993 \\
\hline \multicolumn{7}{|l|}{ Guaje Field } \\
\hline Well G-1 & 12.00 & 0.03 & 3 & $<1$ & $<1$ & $<1$ \\
\hline Well G-1A & 134.10 & 108.20 & 28 & 36 & 9 & 7 \\
\hline Well G-2 & 129.00 & 97.10 & 27 & 33 & 8 & 7 \\
\hline Well G-3 & - & - & - & - & - & - \\
\hline Well G-4 & 12.00 & - & 3 & - & $<1$ & - \\
\hline Well G-5 & 114.40 & 92.20 & 24 & 31 & 7 & 6 \\
\hline Well G-6 & 70.20 & - & 15 & - & 5 & - \\
\hline Subtotal & 471.70 & 297.50 & 100 & 100 & 29 & 20 \\
\hline \multicolumn{7}{|l|}{ Pajarito Field } \\
\hline Well PM-1 & 92.70 & 63.90 & 9 & 7 & 6 & 5 \\
\hline Well PM-2 & 277.70 & 267.80 & 27 & 31 & 18 & 18 \\
\hline Well PM-3 & 307.40 & 168.50 & 29 & 19 & 20 & 12 \\
\hline Well PM-4 & 158.30 & 249.70 & 15 & 29 & 10 & 16 \\
\hline Well PM-5 & 208.40 & 126.00 & 20 & 14 & 14 & 9 \\
\hline Subtotal & $1,044.50$ & 875.90 & 100 & 100 & 71 & 60 \\
\hline \multicolumn{7}{|l|}{ Otowi Field } \\
\hline Well 0-4 & 0 & 283.80 & - & 100 & - & 19 \\
\hline Subtotal & 0 & 283.80 & - & - & - & - \\
\hline Total Potable & $1,529.60$ & $1,457.23$ & - & - & 100 & 99 \\
\hline Water Canyon Gallery & 0.12 & 6.40 & - & - & $<0.1$ & $<0.1$ \\
\hline Guaje Reservoir & - & 0.50 & - & - & - & - \\
\hline Los Alamos Reservoir & - & - & - & - & - & - \\
\hline Total Nonpotable & 0.12 & 6.90 & - & - & $<0.01$ & $<0.01$ \\
\hline \multicolumn{7}{|l|}{ Total Production from } \\
\hline Permitted Sources & $1,529.70^{\mathrm{a}}$ & $1,464.13$ & - & - & 100 & 100 \\
\hline
\end{tabular}

ancludes 13.4 million gal. nonpotable usage for road construction from Well LA-2.

\section{A. Guaje Well Field}

The Guaje Well Field consists of seven wells ranging in depths from 1,500 to 2,000 ft. Wells G-1, -2 , $-3,-4$, and -5 were completed in 1950 . Well G-1A was completed in 1954, and Well G-6 was placed in service in 1964. Almost all of the 1993 production came from three of the wells: G-1A, G-2, and G-5. Attempted rehabilitation of Well G-3 in 1986 damaged their casings beyond repair and the well was taken out of production. During 1993 there was little, if any, production from Wells G-1, G-4, and G-6. The yield of the wells had declined due to deterioration of their casings to a point where it was not considered economically feasible to pump them. Though the wells were not pumped, water level data were collected for the year. There is no water level recorder on Well G-3; thus, there has been no water level data collected from the well since 1986. 
The production from the Guaje Well Field decreased about $147 \times 10^{6}$ gal., from $472 \times 10^{6}$ gal. in 1992 to $278 \times 10^{6}$ gal. in 1993 . The well field contributed about $20 \%$ of the total production in 1993 (Table 3 ).

The combined pumping rate declined about $629 \mathrm{gpm}$, from $1,912 \mathrm{gpm}$ in 1992 to $1,283 \mathrm{gpm}$ in 1993 . The decline represents the pumping rate of the three wells (G-1, G-4, and G-6) that were not pumped during the year. The pumping rate of the three pumped wells (G-1A, G-2, and G-5) was 1,283 gpm, similar to that for the same wells in 1992 (Table 4). There was no significant change in the specific capacities of the three pumped wells in 1993 as compared with the previous year (Table 4).

The average nonpumping water levels in both the pumped wells and the wells that were not pumped were slightly higher in 1993 than in 1992 (Table 5). In the pumped wells, the water level rose an average of about $3 \mathrm{ft}$, while in the other three wells the water levels rose an average of about $11 \mathrm{ft}$. The higher water levels are due to the decline in pumpage from the field in 1993 compared with the previous year. These water changes are normal and indicate some recovery (Figure 3 ).

Table 4. Average Pumping Rate and Specific Capacity, 1992 and 1993

\begin{tabular}{|c|c|c|c|c|}
\hline & \multicolumn{2}{|c|}{$\begin{array}{c}\text { Average } \\
\text { Pumping Rate } \\
\text { (gpm) }\end{array}$} & \multicolumn{2}{|c|}{$\begin{array}{c}\text { Average } \\
\text { Specific Capacity } \\
\text { (gpm per ft of drawdown) }\end{array}$} \\
\hline & 1992 & 1993 & $\overline{1992}$ & 1993 \\
\hline \multicolumn{5}{|l|}{ Guaje Field } \\
\hline Well G-1 & 186 & - & 1.2 & - \\
\hline Well G-1A & 478 & 467 & 13.3 & 13.7 \\
\hline Well G-2 & 424 & 418 & 13.7 & 13.5 \\
\hline Well G-3 & - & - & - & - \\
\hline Well G-4 & 179 & - & 1.1 & - \\
\hline Well G-5 & 376 & 398 & 9.9 & 10.8 \\
\hline Well G-6 & 268 & - & 3.3 & - \\
\hline Subtotal & 1,911 & 1,283 & $7.1^{\mathrm{a}}$ & $12.7^{\mathrm{a}}$ \\
\hline \multicolumn{5}{|l|}{ Pajarito Field } \\
\hline Well PM-1 & 617 & 591 & 25.7 & 28.1 \\
\hline Well PM-2 & 1,328 & 1,305 & 19.2 & 18.9 \\
\hline Well PM-3 & 1,419 & 1,391 & 59.1 & 53.5 \\
\hline Well PM-4 & 1,278 & 1,295 & 31.2 & - \\
\hline Well PM-5 & 1,233 & 1,229 & 12.7 & 12.6 \\
\hline Subtotal & 5,875 & 5,811 & $29.6^{a}$ & $28.3^{2}$ \\
\hline \multicolumn{5}{|l|}{ Otowi Field } \\
\hline Well O-4 & - & 1,603 & - & 60.5 \\
\hline Subtotal & - & 1,603 & - & 60.5 \\
\hline Total & 7,786 & 8,697 & - & - \\
\hline
\end{tabular}

${ }^{a}$ Average specific capacity. 
Table 5. Average Water Levels for Nonpumping and Pumping Wells and Average Drawdown, 1992 and 1993

Average Depth to Water

\begin{tabular}{|c|c|c|}
\hline $\begin{array}{l}\text { Nonpumping } \\
\text { (ft) }\end{array}$ & $\begin{array}{l}\text { Pumping } \\
\text { (ft) }\end{array}$ & $\begin{array}{l}\text { Average } \\
\text { Drawdown } \\
\text { (ft) }\end{array}$ \\
\hline 1993 & 1992 & $\overline{1992}$ \\
\hline
\end{tabular}

\begin{tabular}{|c|c|c|c|c|c|c|}
\hline $\begin{array}{l}\text { Los Alamos Field } \\
\text { Well LA-2 }\end{array}$ & - & 一 & - & - & - & - \\
\hline Average per field & - & - & - & - & - & - \\
\hline \multicolumn{7}{|l|}{ Guaje Field } \\
\hline Well G-1 & 283 & 280 & 439 & - & 156 & - \\
\hline Well G-1A & 325 & 321 & 361 & 355 & 36 & 34 \\
\hline Well G-2 & 370 & 368 & 401 & 399 & 31 & 31 \\
\hline Well G-3 & - & - & - & - & - & - \\
\hline Well G-4 & 387 & 374 & 544 & - & 157 & - \\
\hline Well G-5 & 470 & 466 & 508 & 503 & 38 & 37 \\
\hline Well G-6 & 591 & 575 & 673 & - & 82 & 一 \\
\hline Average per field & 404 & 397 & 487 & 419 & 83 & 34 \\
\hline \multicolumn{7}{|l|}{ Pajarito Field } \\
\hline Well PM-1 & 756 & 758 & 780 & 779 & 24 & 21 \\
\hline Well PM-2 & 860 & 855 & 929 & 924 & 69 & 69 \\
\hline Well PM-3 & 770 & 771 & 794 & 797 & 24 & 26 \\
\hline Well PM-4 & 1,084 & - & 1,125 & - & 41 & 一 \\
\hline Well PM-5 & 1,248 & 1,224 & 1,345 & 1,321 & 97 & 97 \\
\hline Average per field & 944 & 902 & 955 & 904 & 51 & 53 \\
\hline \multicolumn{7}{|l|}{ Otowi Field } \\
\hline Well 0-4 & - & 861 & - & 889 & - & 28 \\
\hline Average per field & - & 861 & - & 889 & - & 28 \\
\hline
\end{tabular}

\section{B. Pajarito Well Field}

The Pajarito Well Field consists of five wells. The wells were completed over a 17-year period, from 1965 through 1982, and range in depths from 2,300 to 3,100 ft. Because they are located on the Pajarito Plateau, the depths to water range from about $750 \mathrm{ft}$ at Well PM-1 to more than 1,200 ft at Well PM-5. During 1993 the following wells were down for repairs: Well PM-3 from September through December, Well PM-4 from January through July; and Well PM-5 from January through March. Due to a malfunction of the recorder, no water level data were collected from Well PM-4 for the entire year.

The production from the Pajarito Well Field in 1993 was about $876 \times 10^{6}$ gal., a decrease of $168 \times$ $10^{6}$ gal. from the $1,044 \times 10^{6}$ gal. produced in 1992 (Table 3). The field contributed about $60 \%$ of the total 1993 production. The production from Wells PM-2, -3 , and -4 represented about $46 \%$ of the total water produced at Los Alamos in 1993 (Table 3).

The average pumping rates of the Pajarito wells ranged from 591 to $1,391 \mathrm{gpm}$ (Table 4). Four of the wells (PM-2, $-3,-4$, and -5 ) are high-yield wells with pumping rates over $1,000 \mathrm{gpm}$ (Table 4). The pumping rates from the individual wells varied slightly from 1992 to 1993 , with a decrease of about $64 \mathrm{gpm}$ from 5,875 gpm in 1992 to $5,811 \mathrm{gpm}$ in 1993. 

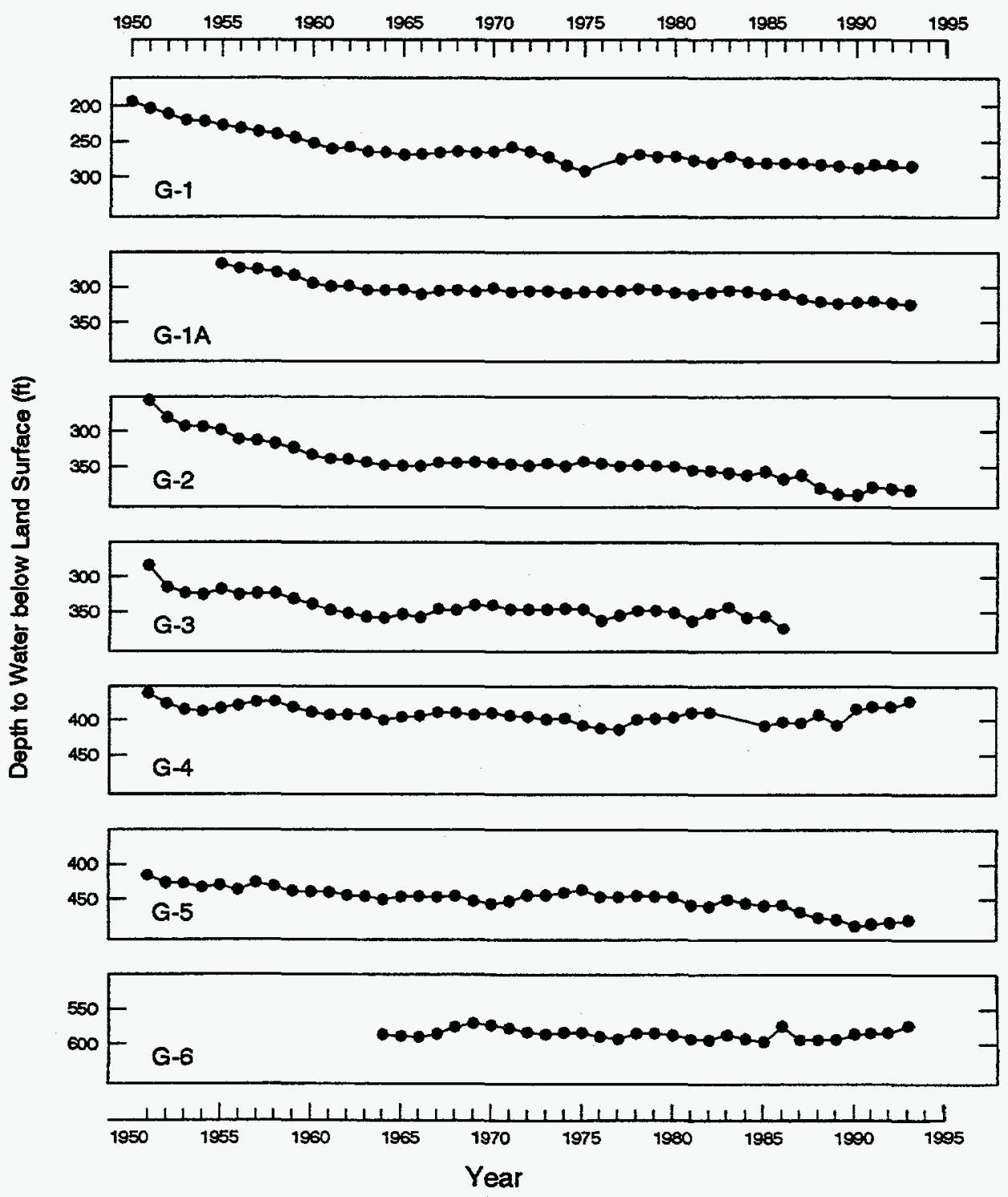

Figure 3. Nonpumping water levels in wells in the Guaje Well Field.

The specific capacities of the four wells in 1993 ranged from 12.6 to $53.5 \mathrm{gpm}$ per $\mathrm{ft}$ of drawdown. There was no significant change in the specific capacitors of the wells from 1992 to 1993, though there was some slight variation in the specific capacities of individual wells (Table 4).

The water levels in these wells fluctuated as would be expected from the amount of pumpage (Figure 4). The average nonpumping water levels in the field were slightly higher in 1993 compared with the 1992 average water levels (Table 5). These higher levels were due to the reduced production in 1993 when compared with the production in 1992.

\section{Otowi Well Field}

The Otowi Well Field consists of two wells that were completed in 1990 . Well 0-1 was completed at a depth of $2,497 \mathrm{ft}$, with a static water level of the main aquifer at a depth of about $695 \mathrm{ft}$. Well 0-4 was 


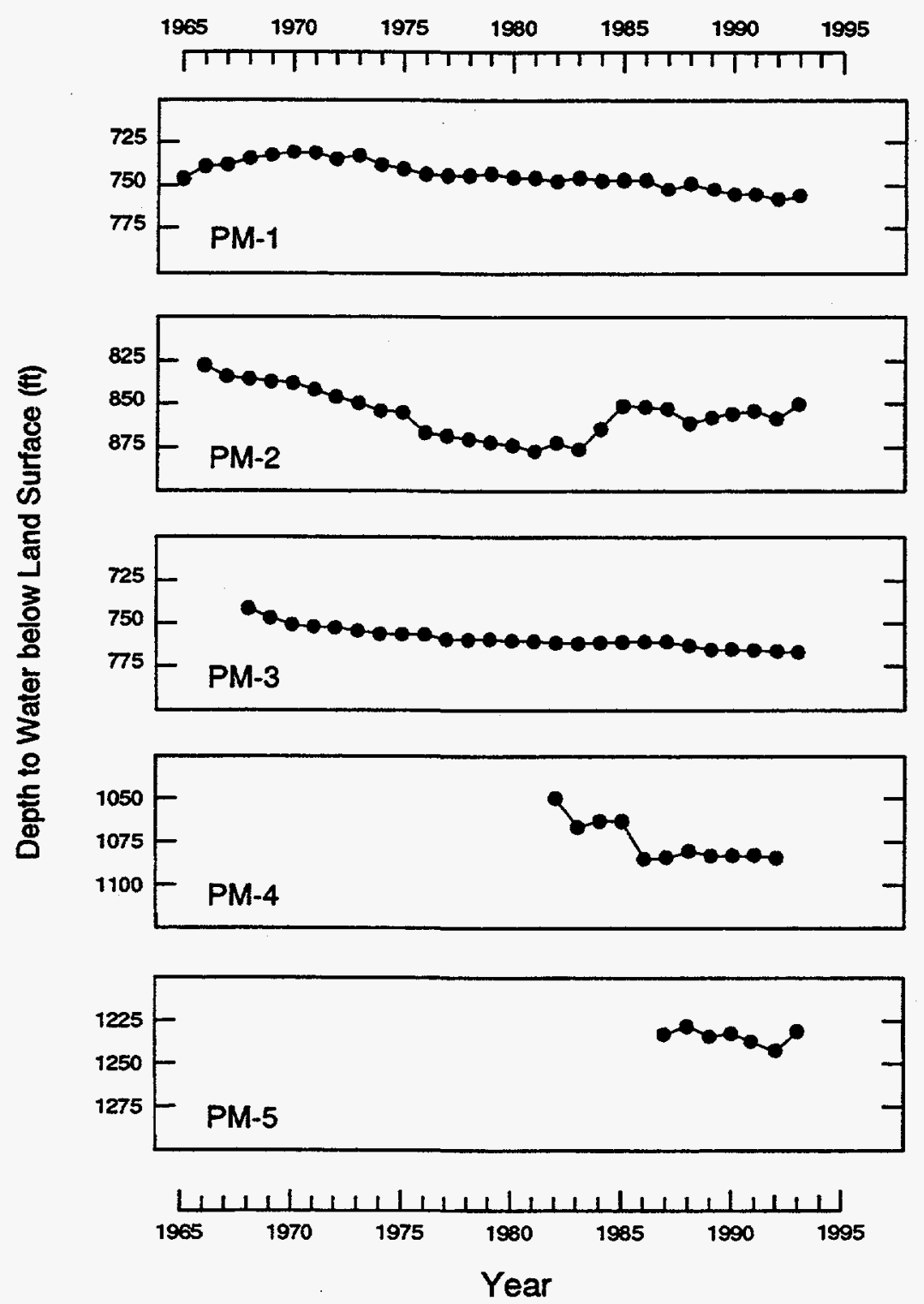

Figure 4. Nonpumping water levels in wells in the Pajarito Well Field.

completed at a depth of $2,585 \mathrm{ft}$, with a static water level at $790 \mathrm{ft}$. Well 0-1 was not operational in 1993. Well O-4 became operational in February. Water level data collection was started in July.

The production from Otowi Well Field in 1993 was from Well O-4. The well produced about $284 \times$ $10^{6}$ gal. or about $19 \%$ of the total amount of water pumped during 1993 (Table 3). The well is a highyield well with a pumping rate of about $1,574 \mathrm{gpm}$. The specific capacity for the period of record was 60.5 gpm per $\mathrm{ft}$ of drawdown (Table 4). The pumping rate and specific capacity are higher than those of any of the high-yield wells in the Pajarito Well Field.

During 1993 at Well O-4 the average nonpumping level was $861 \mathrm{ft}$, with a pumping level of $885 \mathrm{ft}$ and with a drawdown of $28 \mathrm{ft}$ (Table 5). 


\section{WATER CANYON GALLERY AND GUAJE AND LOS ALAMOS RESERVOIRS}

Water Canyon Gallery was a source of potable water from the early days of the Manhattan Project until 1989 (Table 1). Rapid recharge to the gallery causes heavy sediment loads to enter the potable system. In 1989 , to keep the sediments out of the potable system, the use of the gallery was ended. The water from the gallery is used as nonpotable supply at the steam plant.

The spring gallery in Water Canyon is dug about $30 \mathrm{ft}$ into the Bandelier Tuff. The gallery, or tunnel, is framed with timbers and sheet metal to keep the walls and overhead from collapsing. The floor of the gallery is constructed, so as to form a basin to collect the spring flow. About 1 mile of water line connects the gallery to the power plant at TA-16 (S-Site). The water line is not part of the potable system.

The water occurs in the fractures of a welded tuff, which is underlain by a nonwelded tuff (the fractures in the welded tuff contain the water, which is perched on the nonwelded tuff). The gallery furnished only a small amount of water, about $64 \times 10^{6}$ gal., to the power plant during 1993 (Tables 3 and 6). The total discharge from the gallery was not utilized at the steam plant. The excess discharge was released to the environment. The annual use, potable and nonpotable, during the period 1947-1993 is shown in the Table 6.

Water from Guaje and Los Alamos Reservoirs was used for municipal and industrial water supply at Los Alamos during the early days of the Manhattan Project. Use of the reservoirs for potable water supply was discontinued in 1959 because of intermittent periods of turbidity caused by storm runoff and because of difficulties in maintaining bacteriological levels below limits allowed for a municipal supply.

The water from the reservoirs is available for irrigation of lawns and shrubs in the community and Laboratory. Parts of the water lines are above ground and are subject to freezing; thus, water use from the reservoirs is limited to the period from late spring to early fall. During 1993 only a small amount of water, $0.5 \times 10^{6}$ gal., was diverted from Los Alamos Reservoir for irrigation. No water was used from Guaje Reservoir. The age of the distribution system and need for rehabilitation along with operation cost may cause the Laboratory to abandon the irrigation system as it is not economically feasible to operate. The production from the Guaje and Los Alamos Reservoirs for the period of record is shown on Table 6.

\section{QUALITY OF WATER}

The Laboratory conducts two separate programs to monitor the quality of groundwater in the area and to meet regulatory requirements. The first program, under the Laboratory's long-term environmental surveillance program, includes monitoring the quality of water from the supply wells, the gallery in Water Canyon, and reservoirs in Guaje and Los Alamos Canyons.

The second program monitors the quality of water in the Laboratory and county distribution systems to ensure compliance with the Safe Drinking Water Act (SDWA). During 1993, all water collected under the SDWA program at Los Alamos was in compliance with the regulations. The results of both programs will be documented in the report "Environmental Surveillance at Los Alamos during 1993."26

Complete chemical and radiochemical analyses and interpretation of data related to the chemical quality in individual wells in the Los Alamos, Guaje, Pajarito, and Otowi Well Fields, Water Canyon Gallery, and Guaje and Los Alamos Reservoirs were presented in "Water Supply at Los Alamos during 1991."22

\section{LONG-TERM WATER LEVEL TRENDS}

Water levels have been measured in wells in the main aquifer since the late 1940s when the first exploratory wells were drilled by the U.S. Geological Survey. These data have been documented in various reports over the years. This section compiles all the available water level data for the main aquifer and summarizes the changes in graphic form.

The annual summary data on each water supply well has been documented since 1971 in this series of water supply reports. There is one table for each of the wells used as a water supply well at Los Alamos in 
Table 6. Production from Water Canyon Gallery and Guaje and Los Alamos Reservoirsa

\begin{tabular}{|c|c|c|c|}
\hline Year & $\begin{array}{c}\text { Water Canyon } \\
\text { Gallery } \\
\left(10^{6} \text { gal. }\right)\end{array}$ & $\begin{array}{c}\text { Guaje } \\
\text { Reservoir } \\
\left.\text { (10 }{ }^{6} \text { gal. }^{6}\right)\end{array}$ & $\begin{array}{c}\text { Los Alamos } \\
\text { Reservoir } \\
\text { (10 gal.) }\end{array}$ \\
\hline \multicolumn{4}{|c|}{ Municipal Water-Supply Production } \\
\hline 1947 & & 87.8 & 21.7 \\
\hline 1948 & & 119.8 & 21.9 \\
\hline 1949 & & 116.1 & 14.7 \\
\hline 1950 & & 79.9 & 20.6 \\
\hline 1951 & & 41.0 & 10.5 \\
\hline 1952 & & 131.0 & 33.6 \\
\hline 1953 & & 58.0 & 14.8 \\
\hline 1954 & & 66.0 & 16.9 \\
\hline 1955 & & 71.0 & 18.1 \\
\hline 1956 & & 24.0 & 4.8 \\
\hline 1957 & & 213.0 & 54.8 \\
\hline 1958 & & 193.0 & 49.4 \\
\hline \multicolumn{4}{|c|}{ Nonpotable Production } \\
\hline 1972 & & 5.8 & - \\
\hline 1973 & & 9.7 & - \\
\hline 1974 & & 4.9 & - \\
\hline 1975 & & 5.3 & - \\
\hline 1976 & & 4.4 & - \\
\hline 1977 & & 4.1 & - \\
\hline 1978 & & 2.8 & - \\
\hline 1979 & & 3.7 & 1.3 \\
\hline 1980 & & 4.7 & 2.3 \\
\hline 1981 & & 2.7 & 2.1 \\
\hline 1982 & & 3.4 & 2.8 \\
\hline 1983 & & 3.4 & 1.4 \\
\hline 1984 & & 3.0 & 1.3 \\
\hline 1985 & & 2.8 & 0.9 \\
\hline 1986 & & 2.4 & 1.5 \\
\hline 1987 & & 2.8 & 3.2 \\
\hline 1988 & & 2.4 & 1.4 \\
\hline 1989 & & 4.6 & 3.3 \\
\hline 1990 & 9.30 & 2.2 & 4.6 \\
\hline 1991 & 12.00 & 1.5 & 2.4 \\
\hline 1992 & 0.12 & - & - \\
\hline 1993 & 6.40 & - & 0.5 \\
\hline
\end{tabular}

${ }^{\mathrm{a}}$ Guaje and Los Alamos Reservoir municipal supply 1947-1959; irrigation 1972-1990. Water Canyon Gallery municipal supply 1947-1989; industrial supply 1990 (see Table 1 and Appendix).

b Production from Guaje Reservoir for 1951-1958 is estimated. 
the Appendix: Annual Statistics on Aquifer Characteristics. Each table includes annual average information on the water produced and both nonpumping and pumping water levels. Notes on each table have been added for the first time in this report to indicate information about the water level at time of completion of the well.

Because all the wells in the Los Alamos Field have either been abandoned and plugged (see Section VII) or turned over to San Ildefonso Pueblo, this year's report will be the final documentation for those water supply wells. It is anticipated that some future measurement of water levels will be possible in the remaining Los Alamos Field wells (LA-1B, LA-2, and LA-5) under cooperative agreements between the Pueblo, the Bureau of Indian Affairs, and the Department of Energy.

One additional table has been added to the Appendix this year that summarizes the data for the test wells reaching the main aquifer. The table is Water Levels in Main Aquifer Test Wells (page 46). The table includes completion information, static water levels, and changes in water levels in main aquifer test wells, which show the calculated change in water level as compared with the level at time of completion.

The test well water level data were compiled from the original records in the files of the Water Quality and Hydrology Group. Some of the data in the table represent averages when more than one measurement was made during a given year. During 1993, a program was underway to equip each test well with a transducer and automatic data recording capability. The data in the table for 1993 represent the final reading of water level recorded during 1993. In future years it is anticipated that the automated data collection will permit presentation of data on shorter term fluctuations in water levels throughout the year.

A summary of the water level changes since the late 1940s is presented in several graphs. Data for three water supply well fields are presented for the Los Alamos (Figure 5), Guaje (Figure 6), and Pajarito (Figure 7) Well Fields. No graph was made for the Otowi Field as only 1 year of data is available for the single well, Otowi-4 (see Appendix tables). Trends in the main aquifer test wells are depicted in a separate graph (Figure 8).

The levels in the Los Alamos Well Field (Figure 5) generally ranged from about 40 to $140 \mathrm{ft}$ below initial levels until 1990, when the field was taken out of production. Since then levels have trended back toward initial conditions. The easternmost wells, which were artesian at completion, have regained most of their levels; LA-1B has again become artesian.

The levels in the Guaje Well Field (Figure 6) have ranged from almost no decline to about $120 \mathrm{ft}$ of decline since 1950. In this field the westernmost wells show the least decline overall, and they have recovered significantly in recent years with somewhat lower production. Wells G-4 and G-6 recovered significantly in 1993 when they were not pumped.

The wells in the Pajarito Well Field (Figure 7) have always been the best producers, with generally much higher specific capacities. As expected, they show the least decline in water levels; since 1990, about 20 to $40 \mathrm{ft}$.

The test wells penetrating to the main aquifer show declines ranging from less than 10 to about $35 \mathrm{ft}$ over the 45-year period of record (Figure 8). They fall into geographic groups. The westernmost well, TW-4, shows less that $10 \mathrm{ft}$ of change. The southernmost group of wells, DT-5A, DT-9, and DT-10, all located near TA-49, show a decline of about 10 to $15 \mathrm{ft}$ since 1960 . The one well in the central part of the plateau, TW-8, shows a decline of about $25 \mathrm{ft}$, within the range of declines shown by the Pajarito Field supply wells. The north-central wells, TW-2 and TW-3, both show about $35 \mathrm{ft}$ of decline over the 45 -year period of record.

One test well, TW-1, showed an apparent increase in water level after many years of no measurements (see Appendix tables) and was not depicted on the graph. The anomalous behavior of this well is not understood and is under investigation. Some preliminary tests to determine a possible reason for its behavior are discussed in the two most recently published Environmental Surveillance Reports for Los Alamos. ${ }^{27,28}$ There is some indication of communication with the surface as reflected by low level tritium measurements. ${ }^{28}$ 


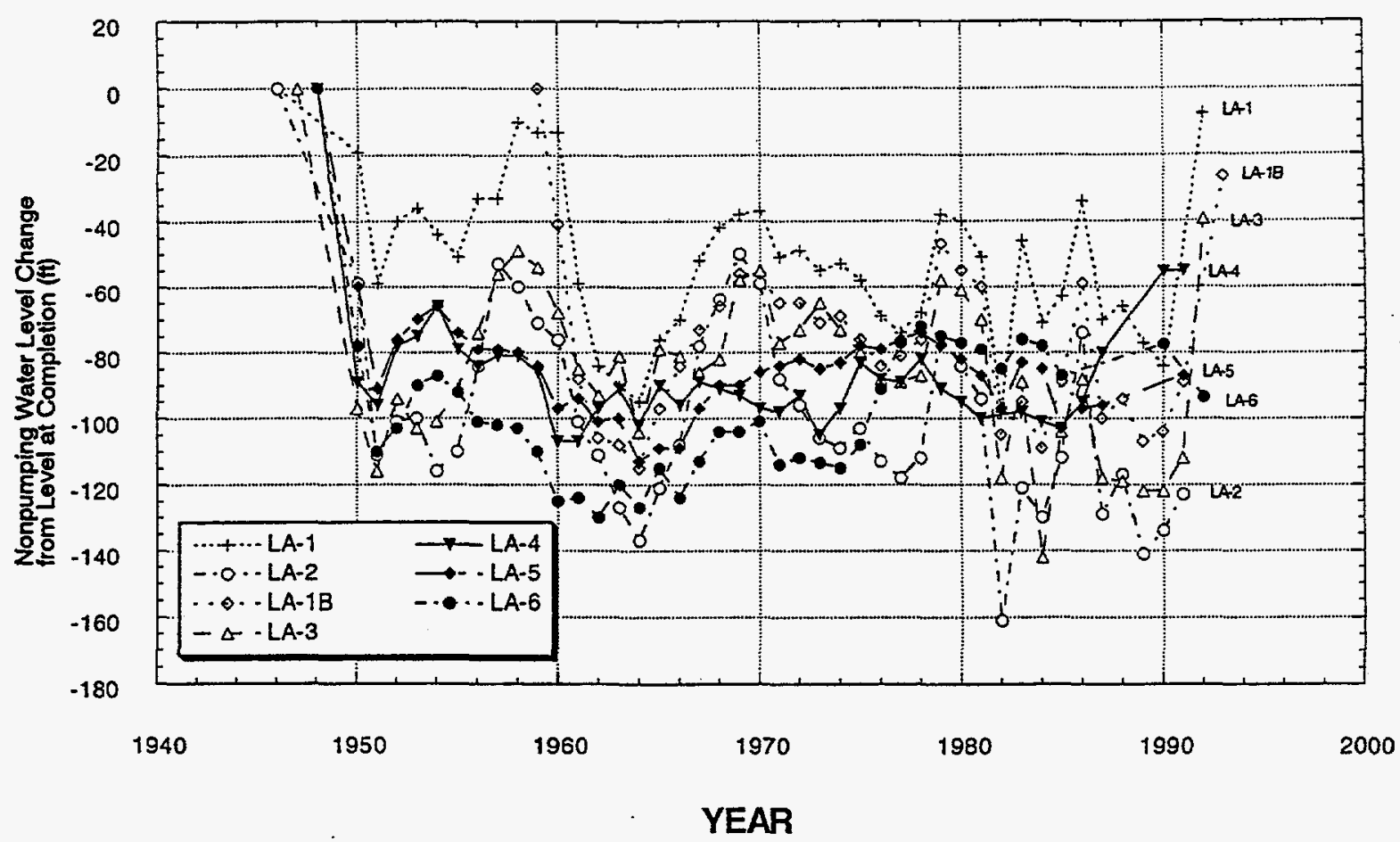

Figure 5. Los Alamos Well Field.

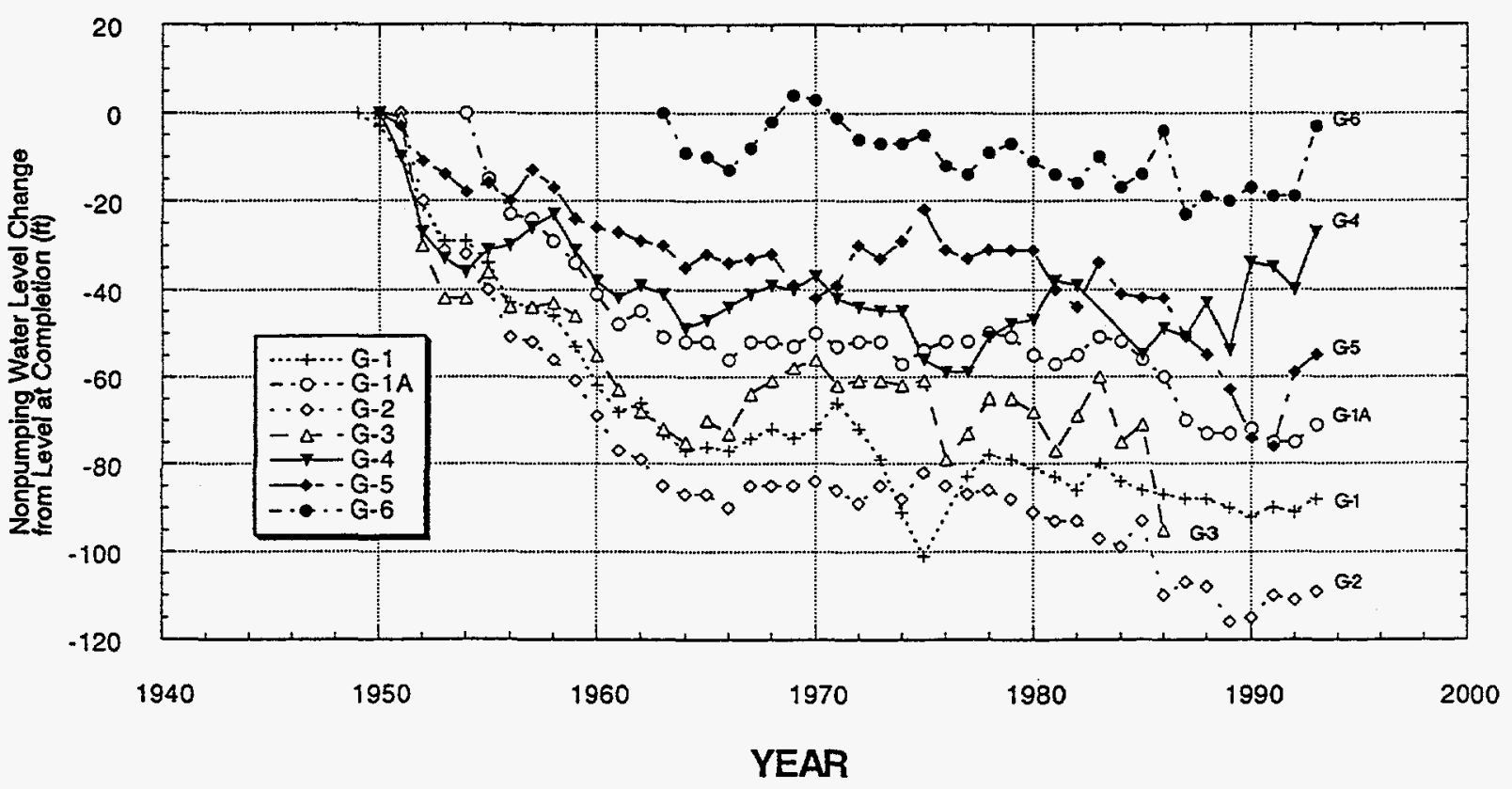

Figure 6. Guaje Well Ficld. 


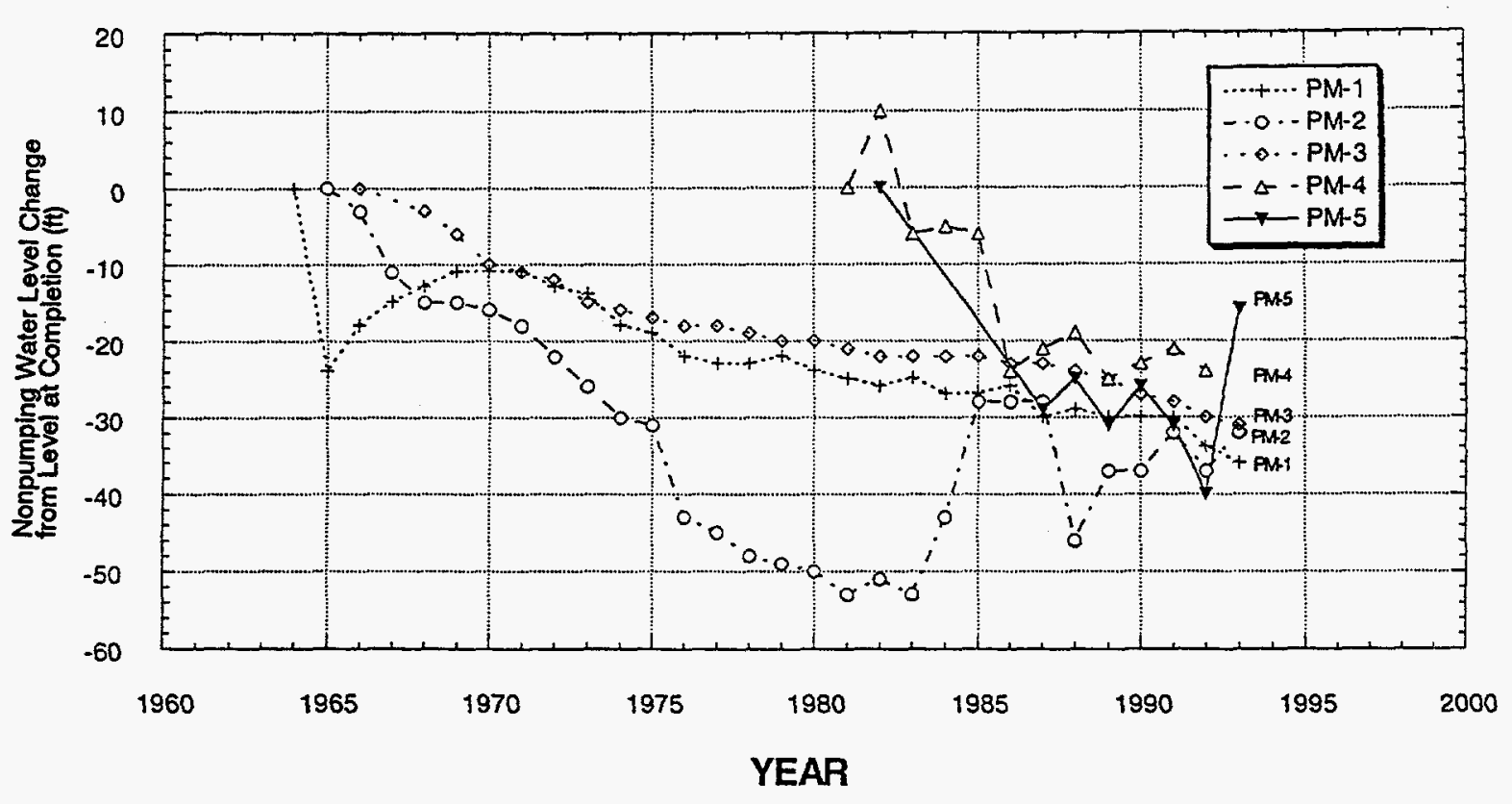

Figure 7. Pajarito Well Field.

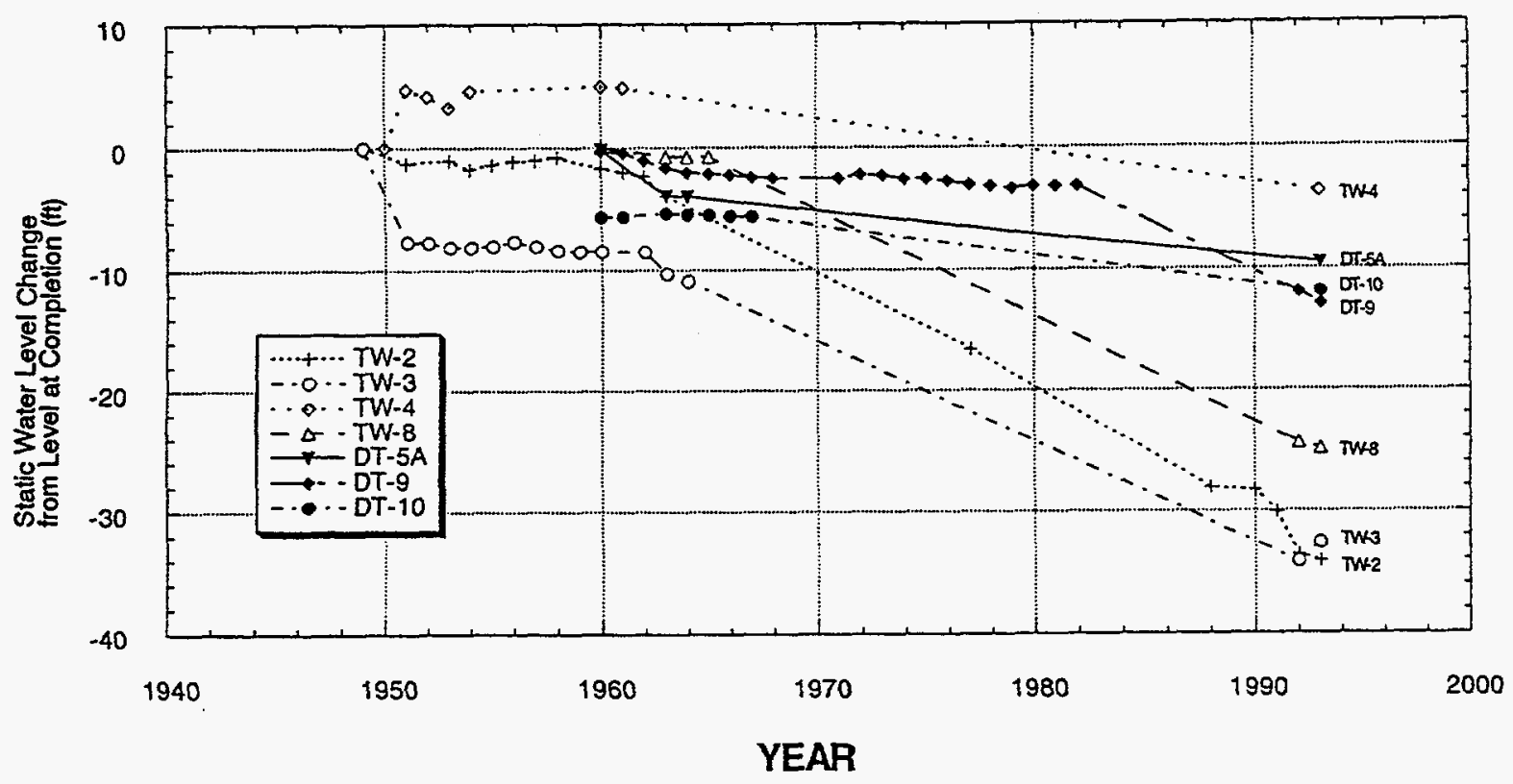

Figure 8. Main aquifer test wells. 
Another interpretation of the changes in water levels is presented as a map in Figure 9. This map of generalized water level contours provides a simplified indication of how the water levels have changed in a geographic context. The map depicts contours for "prepumping conditions" based on the initial water levels measured in each well when drilled; and for "1993 conditions" based on the measured static or nonpumping water levels at the end of 1993 . This map must be viewed with some understanding of its limitations; it is not a true potentiometric contour map.

A potentiometric contour map is normally a presentation of the piezometric surface of a uniform aquifer or hydrologic unit at some point in time. This is not practicable for Los Alamos at present because of the need to cover the area by using data from both test wells and producing water supply wells. Test wells penetrate and therefore permit measuring water levels in only the top (10 to $100 \mathrm{ft}$ ) of the uppermost waterbearing layers. The producing supply wells penetrate much thicker groups (hundreds to more than 1,000 $\mathrm{ft}$ ) of water-bearing layers in several hydrologically different formations. This deeper penetration results in water levels that "average" the water pressures in all the layers. The nonpumping water levels also reflect some influence of recent pumping in the producing wells and have not fully recovered static levels. Additionally, the "prepumping contours" are based on data collected at different times, as the various wells were drilled. However, such data are the closest approximation we have to "undisturbed" conditions.

Given these limitations, the map in Figure 9 permits a quick visualization of the relative changes in different parts of the Los Alamos area. The largest changes, at about $100 \mathrm{ft}$, occurred in the vicinity of the Guaje and Los Alamos Well Fields. Intermediate changes, at about $30 \mathrm{ft}$, have occurred in the central portion generally influenced by the higher yielding Pajarito and Otowi Well Fields. The smallest changes, at about $10 \mathrm{ft}$, occurred to the west and south where no wells are pumped, and adjacent to the Rio Grande where the artesian conditions have resulted in nearly complete recovery in the easternmost wells of the Los Alamos Field. A possible generalization is that the overall pumping of water is greater than the recharge or movement of water into the area, apparently from the west. The importance of these declines may be partly based on comparison with the thickness of the aquifer. The maximum declines of about $100 \mathrm{ft}$, in the Guaje and Los Alamos Fields, are less than $1 \%$ of the several-thousand-ft interval of saturated formations underlying the Pajarito Plateau.

\section{AQUIFER TEST AT SUPPLY WELL 0-4}

A 22-day pump test was conducted in the municipal water supply well Otowi-4 (O-4) from February 24 to March 18,1993. The pumping rate during this test averaged 1,660 gal. per minute (gpm), and fluctuated less than $2 \%$ (i.e., $30 \mathrm{gpm}$ ) as seen in Figure 10a. The total volume of water extracted during this test was $\mathbf{5 2 . 4 8}$ million gal. in 22.042 days. At frequent intervals throughout the pump test, water production rates in well Otowi-4 were measured with a totalizer-type in-line flow meter and stop watch. Total flows were averaged over 5- to 10-minute intervals to establish flow rates.

Drawdown histories were recorded in O-4, and Test Well 3 (TW-3, located $413 \mathrm{ft}$ east of Otowi-4) with automatic recording pressure transducers at 60 -minute intervals. Drawdown data (s) from wells TW-3 and 0-4 are plotted in Figures $10 \mathrm{~b}$ and 11, respectively. A diurnal barometric pressure effect is apparent in each figure and is represented by small amplitude repeating "bumps" that are superimposed onto the drawdown trends of each well.

The plots in Figures $10 \mathrm{~b}$ and 11 both suggest that the main aquifer surrounding $0-4$ behaved like a leaky confined aquifer during the test. The bend in the curve for O-4 (Figure 11) clearly suggests that the spreading cone of depression emanating from $0-4$ encountered a recharge effect after about 5.5 days of constant pumping. This aquifer response is plausible because $0-4$ is screened in the highly stratified sediments within the formations of the Santa Fe Group. ${ }^{20}$ These sediments consist of mixed conglomerates and gravels with some basalts, sandstones, siltstones, and clays. Well 0-4 probably derives most of its water yield from numerous interbedded permeable layers within these Santa Fe sediments, resulting in vertical seepage into these major production zones from less permeable adjacent layers. Supporting 

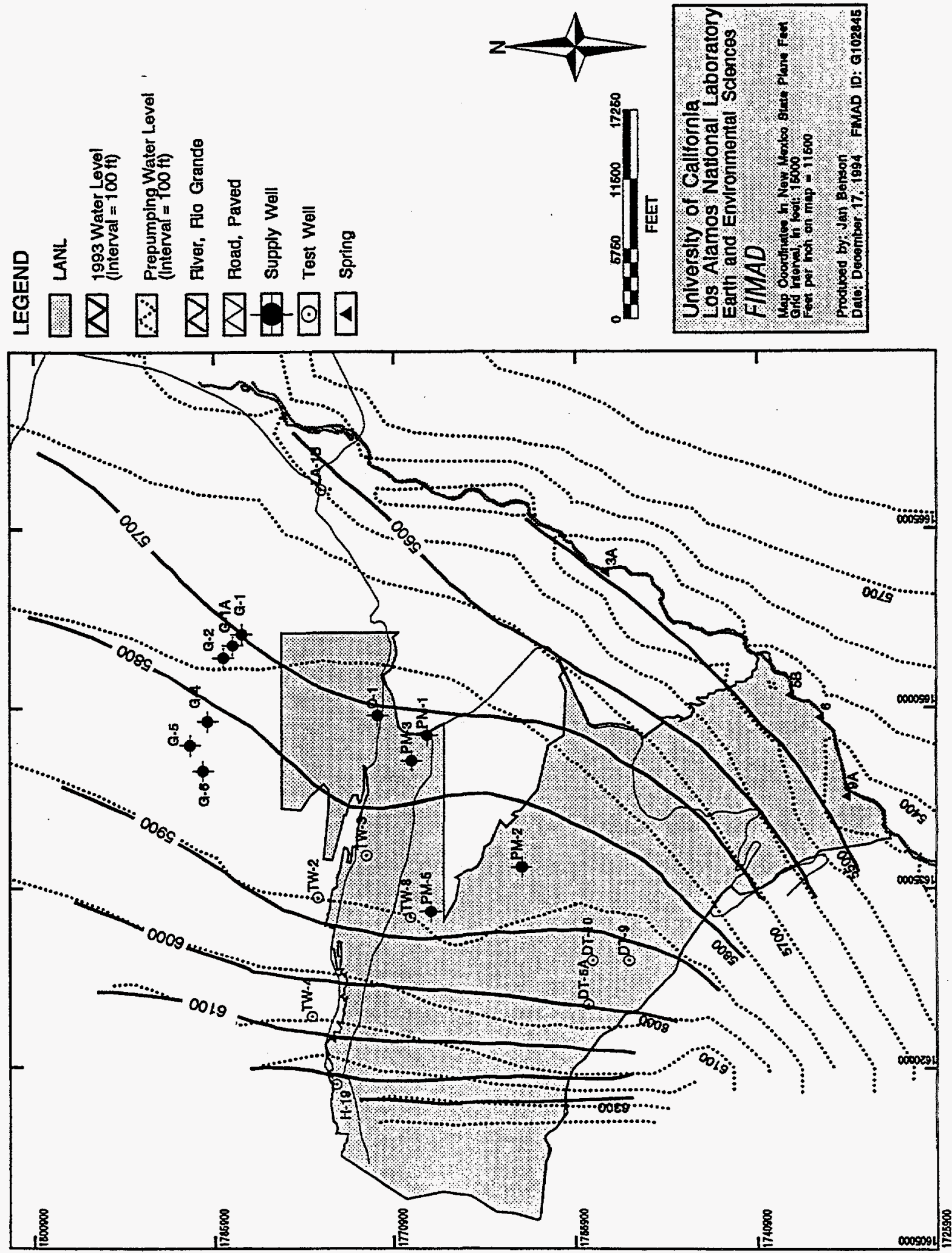

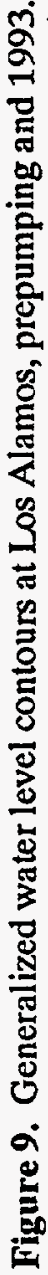



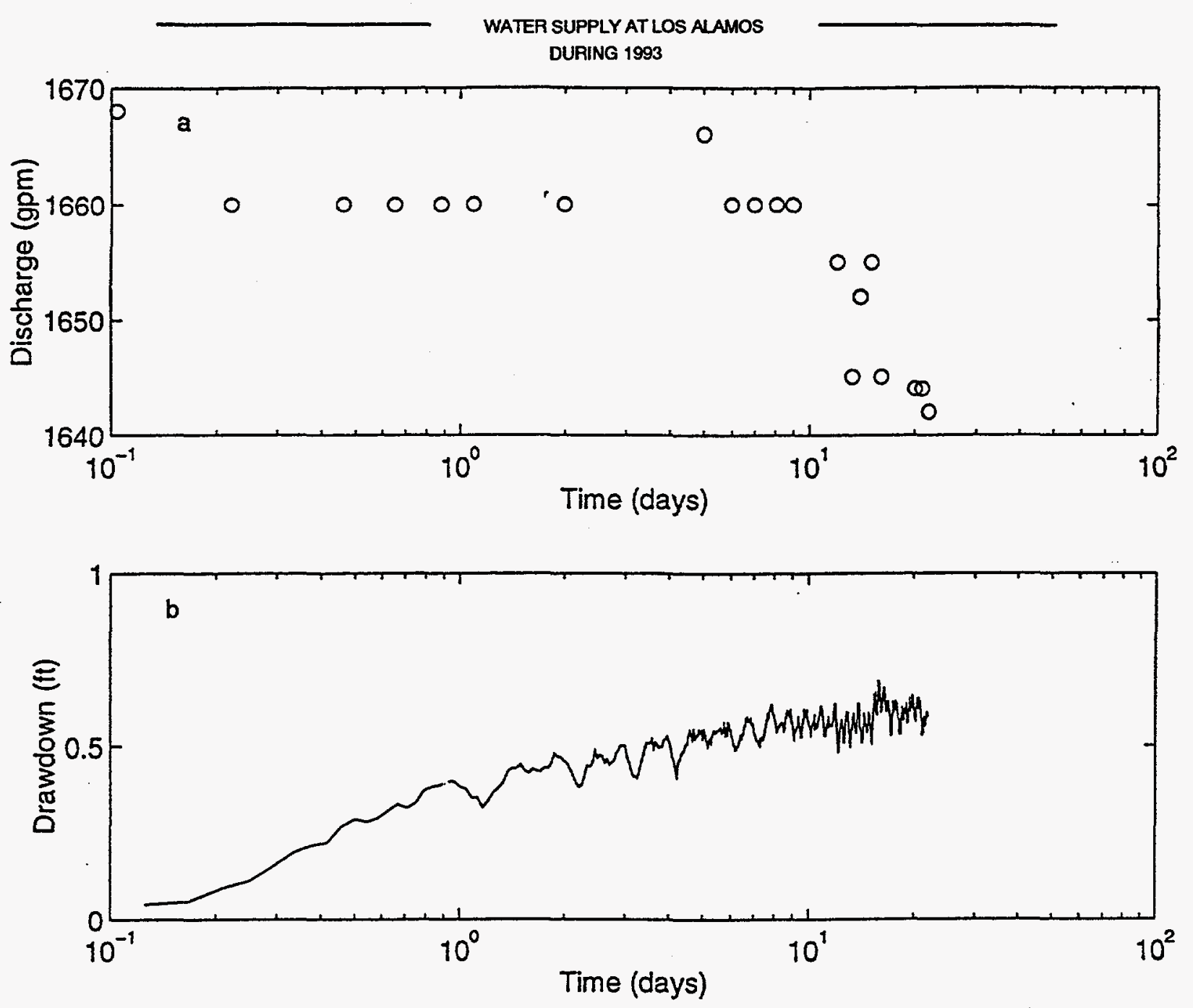

Figure 10. Pump test analysis at Well Otowi-4: a, discharge history in Otowi-4; and $\mathbf{b}$, drawdown response in Test Well TW-3, located $413 \mathrm{ft}$ away, from February 24 to March $18,1993$.

evidence for this interpretation is provided by the negligible drawdown in Well TW-3 (Figure 10b), which is completed several hundred feet above the 0-4 screened interval as shown in Table 7.

Municipal water supply wells PM-3 (located some 6,029 ft southeast of 0-4), and PM-5 (located some $6,714 \mathrm{ft}$ southwest of $0-4$ ) remained off during this test and were also used as observation wells; however, no recordable drawdown data were obtained at either of these two wells in response to pumpage at 0-4. Because these two supply wells were screened over intervals similar to 0-4 (see Table 7), their lack of observable drawdown response is fairly conclusive evidence that the cone of depression did not extend to those distances. In addition, no recordable drawdown was observed in either test well TW-2, located to the northwest, or in test well TW-8, located to the southwest. However, these two test wells are also screened over intervals several hundred feet higher than 0-4 (Table 7).

The standard Cooper-Jacob procedure was used to compute hydrologic parameters of transmissivity (T) and storage coefficient (S). ${ }^{29}$ The observed drawdown (s) from Otowi-4 is plotted against time (t) on semilogarithmic paper, as shown in Figure 11. The best-fitting straight line is drawn through the data 


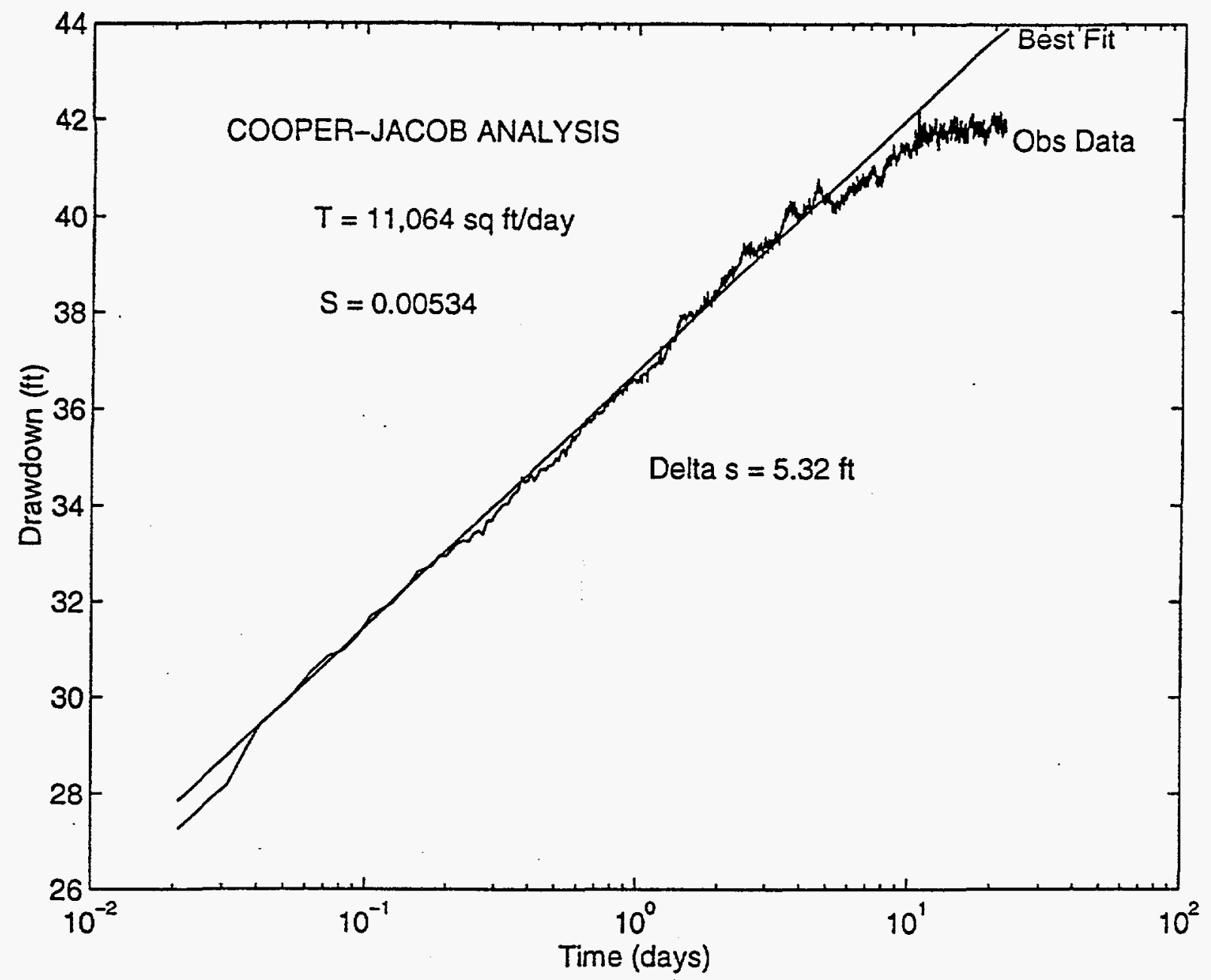

Figure 11. The Cooper-Jacob method analysis of drawdown data from Well Otowi-4. The computed $T$ and $S$ values are 11,064 square $\mathrm{ft}$ per day, and 0.00534 , respectively. Note that a recharge effect became important after about 5.5 days of pumpage.

Table 7. Static Water Levels on February 24, 1993, and Screened Intervals in Selected Observation Wells.

\begin{tabular}{lccc} 
Well & Radial Distance $^{\mathrm{a}}$ & Water Level $^{\mathbf{a}}$ & Screened Interval $^{\mathbf{a}}$ \\
\hline Otowi-4 & 0.75 & 5,761 & $5,512-4,042$ \\
TW-3 & 413.00 & 5,817 & $5,790-5,780$ \\
TW-2 & $5,380.00$ & 5,855 & $5,880-5,824$ \\
TW-8 & $5,929.00$ & 5,886 & $5,925-5,813$ \\
& & & \\
PM-5c $^{\mathrm{b}}$ & $6,714.00$ & 5,861 & $5,656-4,024$ \\
PM-3 $^{\mathrm{c}}$ & $6,029.00$ & 5,875 & $5,636-4,360$
\end{tabular}

${ }^{a}$ All units are in feet; water levels and screened intervals are relative to mean sea level. bOtowi-4 was the pumping well for the test described in this report.

cMunicipal water supply well remained off from January through March 1993. 
points, giving more weight to the early-time data points (i.e., for $t<5.5$ days) before the recharge effect begins to affect the linear relationship between $s$ and $\log (t)$. The slope $(\Delta s)$ of this best-fitting line is measured over one $\log$ cycle, and $t_{0}$ is estimated where this best-fit line intersects the drawdown axis at $\mathrm{s}=$ 0 . $T$ and $S$ are then computed from

$$
\mathrm{T}=2.303^{*} \mathrm{Q} /\left(4^{*} \pi^{*} \Delta \mathrm{s}\right) \text { and } \mathrm{S}=2.25^{*} \mathrm{~T}^{*} \mathrm{t} / \mathrm{r}^{2}
$$

Note that $r$ represents the radial distance from the pumping well to the observation well where $s$ and $t$ are recorded. In this test, drawdown was measured inside a 2 -in. steel gage line located outside the Otowi4 well casing and connected to the production casing below the pump impellers at the 1,114-ft depth. Here the screen and gravel pack are in close hydraulic communication and have an outside diameter of 18 in. Hence $\mathrm{r}$ was set equal to $0.75 \mathrm{ft}$. From Figure 2 we see that $\Delta \mathrm{s}=5.32 \mathrm{ft}$, and $t_{0}=1.21 \mathrm{e}-07$ days. Thus $\mathrm{T}=11,064 \mathrm{sq} \mathrm{ft} / \mathrm{day}$, and $\mathrm{S}=\mathbf{0 . 0 0 5 3 4}$. These values compare reasonably with those previously reported $\left(T=8,362 \mathrm{sq} \mathrm{ft} /\right.$ day and $\mathrm{S}=\mathbf{0 . 0 0 1 9 3}$ ) for a much shorter step-drawdown test conducted in 1990 at $0-4 .^{20}$ While the test results reported here are more representative of actual conditions in the main aquifer than were earlier $T$ and $S$ values, it should be noted that the drawdown values were still recorded in the production well, and these results are not as desirable as those from a test with a fully penetrating observation well. In particular, the value of $S$ is difficult to determine because the well radius may be affected by gravel pack permeability and well losses.

The drawdown data from TW-3, shown in Figure 10b, was not analyzed quantitatively because this well is completed to a total depth of $815 \mathrm{ft}$ below the surface, with only the bottom $10 \mathrm{ft}$ screened. The top of the screen in 0-4 starts at 1,115 ft below the surface and continues down to $2,574 \mathrm{ft}$ below the surface. ${ }^{20}$ Hence the screened intervals in 0-4 and TW-3 do not overlap. Table 1 clearly illustrates this point.

\section{PLUGGING OF LOS ALAMOS WELLS LA-1, LA-3, LA-4, AND LA-6}

The plugging operations were carried out in accordance to a set of specifications that were approved by the State Engineer. The specifications were written by Glenn Hammock, a consulting engineer. The depth of the wells were determined prior to the plugging operations. The depths determined were always less than the completed depths as the wells in the field tend to fill with sand while being pumped and in some cases the casings may have parted, allowing the gravel packs to fill the holes. In each of the four wells, the volume of cement exceeded the volume of the wells to be plugged. This indicates that some of the neat cement slurry moved into the gravel pack through the casing slots.

The wells were plugged from the bottom to the land surface. A tremmie pipe was set near the bottom of the holes and a slurry of neat cement was pumped into the hole through the tremmie pipe. As the holes were filled with the slurry, a section of the tremmie pipe was removed and pumping continued. The operation continued until cement extended to the surface.

\section{A. Well LA-1}

Well LA-1 was drilled in 1946 and cased to a depth of $870 \mathrm{ft}$ with 12-in.-diameter casing. There were $805 \mathrm{ft}$ of slots between 60 and $805 \mathrm{ft}$. The well was gravel packed. Prior to plugging, the well was sounded at a depth of $180 \mathrm{ft}$. The well was plugged from $180 \mathrm{ft}$ to land surface with about $20.8 \mathrm{cu}$ yd of neat cement. The top $5 \mathrm{ft}$ of the casing and conductor pipe was removed and the annular space was grouted with neat cement.

The 12-in.-diameter casing to a depth of $180 \mathrm{ft}$ would require $5.2 \mathrm{cu}$ yd of cement. About $20.8 \mathrm{cu}$ yd of cement were used, an excess of $15.6 \mathrm{cu}$ yd. During the plugging operation it was noted that the cement plug moved, as if the hole were bridged at the measurement. The excess cement, while filling the hole, probably moved out into the gravel pack. The job was completed August 18, 1993. 


\section{B. Well LA-3}

Well LA-3 was drilled in 1947 and cased to a depth of $870 \mathrm{ft}$ with 12 -in.-diameter casing. There were $760 \mathrm{ft}$ of slotted casing and screens between a depth of 105 and $865 \mathrm{ft}$. The well was gravel packed. Prior to plugging, the well was sounded at a depth of $753 \mathrm{ft}$. The well was plugged from $753 \mathrm{ft}$ to land surface with $31.0 \mathrm{cu}$ yd of neat cement. The top $5 \mathrm{ft}$ of the casing and conductor pipe were removed and the annular space grouted with neat cement.

The 12-in.-diameter casing extending to a depth of $753 \mathrm{ft}$ would require $21.8 \mathrm{cu}$ yd of cement. About $31.0 \mathrm{cu}$ yd were used, an excess of $9.2 \mathrm{cu}$ yd. The excess probably moved out into the gravel pack. The job was completed on August 18, 1993.

\section{Well LA-4}

Well LA-4 was drilled in 1948 and was cased to a depth of $1,965 \mathrm{ft}$. The casing diameter was 12-in. from land surface to $754 \mathrm{ft}$, then reduced to a 10-in. diameter from 754 to $1,965 \mathrm{ft}$. There were $305 \mathrm{ft}$ of slotted casing between $754 \mathrm{ft}$ to $1,964 \mathrm{ft}$. The well was gravel packed. Prior to plugging, the well was sounded at a depth of $778 \mathrm{ft}$. The well was plugged from $778 \mathrm{ft}$ to land surface with $33.0 \mathrm{cu}$ yd of sand cement. The top $5 \mathrm{ft}$ of the casing and conductor pipe were removed and the annular space grouted with neat cement.

The 12-in.-diameter casing to $754 \mathrm{ft}$ and 10-in.-diameter casing from 754 to $778 \mathrm{ft}$ would require $22.4 \mathrm{cu}$ ft of cement. About $33.0 \mathrm{cu}$ yd were used, an excess of $10.6 \mathrm{cu}$ yd. During well rehabilitation in 1987 , a video log of the well indicated that the casing was parted at or near the reduction of the 12-in.diameter casing to 10 -in.-diameter casing at $754 \mathrm{ft}$. The excess cement moved out into the well bore or gravel pack at the casing break or casing slots. The job was completed on August 30, 1993.

\section{Well LA-6}

Well LA-6 was drilled in 1948 and was cased to a depth of 1,790 ft. The casing diameter was 12 -in. from land surface to $597 \mathrm{ft}$ and then reduced to a 10 -in. diameter from 597 to $1,790 \mathrm{ft}$. There were $400 \mathrm{ft}$ of slotted casing between $420 \mathrm{ft}$ to $1,778 \mathrm{ft}$. The well was gravel packed. The well depth in 1977 was about $1,200 \mathrm{ft}$. It was sounded prior to being plugged at a depth of $1,200 \mathrm{ft}$. The well was plugged from $1,200 \mathrm{ft}$ to land surface with $22.5 \mathrm{cu}$ yd of sand cement and $13.02 \mathrm{cu}$ yd of neat cement. The top $5 \mathrm{ft}$ of the casing and conductor pipe were removed and the annular space grouted with neat cement.

The 12-in.-diameter casing to a depth of $597 \mathrm{ft}$ and the 10-in.-diameter casing from 597 to $1,200 \mathrm{ft}$ would require $29.5 \mathrm{cu}$ yd of cement. The well was plugged with $35.5 \mathrm{cu}$ yd of neat cement and sand, an excess of $6.0 \mathrm{cu}$ yd. The excess probably moved out into the gravel pack. The job was completed on August 30, 1993.

\section{SUMMARY}

Operations of wells and well fields in 1993 were satisfactory. Water level trends in the wells were as expected under the current amount of annual pumpage. Future operations of the wells and water supply system should be continued as in the past. The pumps on Wells G-1, G-4, and G-6 should be tested during the year. The three wells have a potential of $600 \mathrm{gpm}$, which in an emergency, with the loss of one or two high-yield wells during peak demand periods in the summer, would be necessary to maintain the required fire protection level in storage tanks. Water level monitoring of the three wells should be continued. Efforts should be made to install water level monitoring equipment on Well G-3 and to repair the equipment on Well PM-4. Continued collection of data from wells and well fields is necessary to evaluate present and future wells and well field operations.

\section{ACKNOWLEDGMENTS}

Statistics on well production were collected by personnel from Johnson Control World Services Inc. and were compiled for this report by the Laboratory's Water Quality and Hydrology Group. 


\section{REFERENCES}

1. W. D. Purtymun and J. E. Herceg, compilers, "Summary of the Los Alamos Municipal WellField Characteristics," Los Alamos Scientific Laboratory report LA-5040-MS (1972).

2. W. D. Purtymun and J. E. Herceg, "Water Supply at Los Alamos During 1971," Los Alamos Scientific Laboratory report LA-5039-MS (1972).

3. W. D. Purtymun and J. E. Herceg, "Water Supply at Los Alamos During 1972," Los Alamos Scientific Laboratory report LA-5296-MS (1973).

4. W. D. Purtymun and J. E. Herceg, "Water Supply at Los Alamos During 1973," Los Alamos Scientific Laboratory report LA-5636-MS (1974).

5. W. D. Purtymun, "Water Supply at Los Alamos During 1974," Los Alamos Scientific Laboratory report LA-5998-MS (1975).

6. W. D. Purtymun, "Water Supply at Los Alamos During 1975," Los Alamos Scientific Laboratory report LA-6461-PR (1976).

7. W. D. Purtymun, "Water Supply at Los Alamos During 1976," Los Alamos Scientific Laboratory report LA-6814-PR (1977).

8. W. D. Purtymun, "Water Supply at Los Alamos During 1977," Los Alamos Scientific Laboratory report LA-7436-MS (1978).

9. W. D. Purtymun, "Water Supply at Los Alamos During 1978," Los Alamos Scientific Laboratory report LA-8074-PR (1979).

10. W. D. Purtymun, "Water Supply at Los Alamos During 1979," Los Alamos Scientific Laboratory report LA-8504-PR (1980).

11. W. D. Purtymun and M. N. Maes, "Water Supply at Los Alamos During 1980," Los Alamos National Laboratory report LA-8977-PR (1981).

12. W. D. Purtymun, N. M. Becker, and M. N. Maes, "Water Supply at Los Alamos During 1981," Los Alamos National Laboratory report LA-9734-PR (1983).

13. W. D. Purtymun, N. M. Becker, and M. N. Maes, "Water Supply at Los Alamos During 1982," Los Alamos National Laboratory report LA-9896-PR (1984).

14. W. D. Purtymun, N. M. Becker, and M. N. Maes, "Water Supply at Los Alamos During 1983," Los Alamos National Laboratory report LA-10327-PR (1985).

15. W. D. Purtymun, N. M. Becker, and M. N. Maes, "Water Supply at Los Alamos During 1984," Los Alamos National Laboratory report LA-10584-PR (1986).

16. W. D. Purtymun, N. M. Becker, and M. N. Maes, "Water Supply at Los Alamos During 1985," Los Alamos National Laboratory report LA-10835-PR (1986).

17. W. D. Purtymun, A. K. Stoker, and M. N. Maes, "Water Supply at Los Alamos During 1986," Los Alamos National Laboratory report LA-11046-PR (1987).

18. W. D. Purtymun, A. K. Stoker, and M. N. Maes, "Water Supply at Los Alamos During 1987," Los Alamos National Laboratory report LA-11478-PR (1989). 
19. W. D. Purtymun, M. N. Maes, and S. G. McLin, "Water Supply at Los Alamos During 1988," Los Alamos National Laboratory report LA-11679-PR (1989).

20. A. K. Stoker, S. G. McLin, W. D. Purtymun, M. N. Maes, and G. Hammock, "Water Supply at Los Alamos During 1989," Los Alamos National Laboratory report LA-12276-PR (1992)

21. W. D. Purtymun, S. G. McLin, A. K. Stoker, M. N. Maes, and G. Hammock, "Water Supply at Los Alamos During 1990," Los Alamos National Laboratory report LA-12471-PR (1993).

22. W. D. Purtymun, S. G. McLin, A. K. Stoker, and M. N. Maes, "Water Supply at Los Alamos during 1991," Los Alamos National Laboratory report LA-12770-PR (1994).

23. W. D. Purtymun, A. K. Stoker, S. G. McLin, and M. N. Maes, "Water Supply at Los Alamos during 1992," Los Alamos National Laboratory report in preparation (1995).

24. W. D. Purtymun, "Hydrologic Characteristics of the Main Aquifer in the Los Alamos Area: Development of Ground Water Supplies," Los Alamos National Laboratory report LA-9957-MS (1984).

25. W. D. Purtymun and A. K. Stoker, "Current Status of Wells and Future Water Supply," Los Alamos National Laboratory report LA-11332-MS (1988).

26. Environmental Protection Group, "Environmental Surveillance at Los Alamos during 1993," Los Alamos National Laboratory report, in preparation (1995).

27. Environmental Protection Group, "Environmental Surveillance at Los Alamos during 1991," Los Alamos National Laboratory report LA-12271-MS (March 1992).

28. Environmental Protection Group, "Environmental Surveillance at Los Alamos during 1992," Los Alamos National Laboratory report LA-12764-ENV (July 1994).

H. Bouwer, Groundwater Hydrology, McGraw-Hill, New York (1978). 


\section{Appendix}

\section{Annual Statistics on Aquifer Characteristics}



Well LA-1

\begin{tabular}{|c|c|c|c|c|}
\hline Year & $\begin{array}{l}\text { Pumping Time } \\
\text { (h) }\end{array}$ & $\begin{array}{c}\text { Production } \\
\left(10^{6} \text { gal. }\right)\end{array}$ & $\begin{array}{l}\text { Pumping Rate } \\
\text { (gpm) }\end{array}$ & $\begin{array}{c}\text { Water Level } \\
\text { (Nonpumping) } \\
\text { (ft) }\end{array}$ \\
\hline 1947 & 3,468 & 54.0 & 259.5 & - \\
\hline 1948 & 2,988 & 34.7 & 193.6 & - \\
\hline 1949 & 1,361 & 26.7 & 327.0 & - \\
\hline 1950 & 563 & 10.5 & 310.8 & 19.0 \\
\hline 1951 & 1,215 & 14.6 & 200.3 & 59.0 \\
\hline 1952 & 286 & 3.4 & 198.1 & 40.0 \\
\hline 1953 & 0 & 0.0 & 0.0 & 36.0 \\
\hline 1954 & 0 & 0.0 & 0.0 & 44.0 \\
\hline 1955 & 690 & 9.7 & 234.3 & 51.0 \\
\hline 1956 & 39 & 0.0 & 0.0 & 33.0 \\
\hline 1957 & 0 & 0.0 & 0.0 & 33.0 \\
\hline 1958 & 0 & 0.0 & 0.0 & 10.0 \\
\hline 1959 & 0 & 0.0 & 0.0 & 13.0 \\
\hline 1960 & 0 & 0.0 & 0.0 & 13.0 \\
\hline 1961 & 0 & 0.0 & 0.0 & 59.0 \\
\hline 1962 & 0 & 0.0 & 0.0 & 84.0 \\
\hline 1963 & 0 & 0.0 & 0.0 & 90.0 \\
\hline 1964 & 0 & 0.0 & 0.0 & 95.0 \\
\hline 1965 & 0 & 0.0 & 0.0 & 76.0 \\
\hline 1966 & 0 & 0.0 & 0.0 & 70.0 \\
\hline 1967 & 0 & 0.0 & 0.0 & 52.0 \\
\hline 1968 & 0 & 0.0 & 0.0 & 42.0 \\
\hline 1969 & 0 & 0.0 & 0.0 & 38.0 \\
\hline 1970 & 0 & 0.0 & 0.0 & 37.0 \\
\hline 1971 & 0 & 0.0 & 0.0 & 51.0 \\
\hline 1972 & 0 & 0.0 & 0.0 & 49.0 \\
\hline 1973 & 0 & 0.0 & 0.0 & 55.0 \\
\hline 1974 & 0 & 0.0 & 0.0 & 53.0 \\
\hline 1975 & 0 & 0.0 & 0.0 & 58.0 \\
\hline 1976 & 0 & 0.0 & 0.0 & 69.0 \\
\hline 1977 & 0 & 0.0 & 0.0 & 74.0 \\
\hline 1978 & 0 & 0.0 & 0.0 & 68.0 \\
\hline 1979 & 0 & 0.0 & 0.0 & 38.0 \\
\hline 1980 & 0 & 0.0 & 0.0 & 40.0 \\
\hline 1981 & 0 & 0.0 & 0.0 & 51.0 \\
\hline 1982 & 0 & 0.0 & 0.0 & 98.0 \\
\hline 1983 & 0 & 0.0 & 0.0 & 46.0 \\
\hline 1984 & 0 & 0.0 & 0.0 & 71.0 \\
\hline 1985 & 0 & 0.0 & 0.0 & 63.0 \\
\hline 1986 & 0 & 0.0 & 0.0 & 34.0 \\
\hline 1987 & 0 & 0.0 & 0.0 & 70.0 \\
\hline 1988 & 0 & 0.0 & 0.0 & 66.0 \\
\hline 1989 & 0 & 0.0 & 0.0 & 77.0 \\
\hline 1990 & 0 & 0.0 & 0.0 & 84.0 \\
\hline
\end{tabular}

NOTE: Well was completed November 1946; initial water level: flowing; surface elevation $5,624 \mathrm{ft}$. Air line and recorder were removed in 1990; water level on March 12, 1992 was $7.61 \mathrm{ft}$ below top of brass valve. Facility was demolished in 1990 and the well was plugged in 1993. 
Well LA-1B

\begin{tabular}{|c|c|c|c|c|c|c|c|}
\hline \multirow[b]{2}{*}{ Year } & \multirow[b]{2}{*}{$\begin{array}{l}\text { Pump } \\
\text { Time } \\
\text { (h) }\end{array}$} & \multirow[b]{2}{*}{$\begin{array}{l}\text { Production } \\
\left(10^{6} \text { gal. }\right)\end{array}$} & \multirow[b]{2}{*}{$\begin{array}{l}\text { Pump } \\
\text { Rate } \\
\text { (gpm) }\end{array}$} & \multicolumn{2}{|c|}{ Water Level } & \multirow[b]{2}{*}{$\begin{array}{l}\text { Drawdown } \\
\text { (ft) }\end{array}$} & \multirow[b]{2}{*}{$\begin{array}{r}\text { Specific } \\
\text { Capacity } \\
\text { (gpm/ft) }\end{array}$} \\
\hline & & & & $\begin{array}{c}\text { Nonpumping } \\
\text { (ft) }\end{array}$ & $\begin{array}{l}\text { Pumping } \\
\text { (ft) }\end{array}$ & & \\
\hline 1960 & 415 & 36.3 & $1,457.8$ & 7.0 & 111.0 & 104.0 & 14.0 \\
\hline 1961 & 3,727 & 124.7 & 557.6 & 54.0 & 154.0 & 100.0 & 5.6 \\
\hline 1962 & 3,936 & 129.1 & 546.7 & 72.0 & 169.0 & 97.0 & 5.6 \\
\hline 1963 & 3,649 & 117.4 & 536.2 & 74.0 & 170.0 & 96.0 & 5.6 \\
\hline 1964 & 4,174 & 130.3 & 520.3 & 81.0 & 183.0 & 102.0 & 5.1 \\
\hline 1965 & 3,007 & 97.9 & 542.6 & 63.0 & 170.0 & 107.0 & 5.1 \\
\hline 1966 & 2,589 & 83.9 & 540.1 & 50.0 & 169.0 & 119.0 & 4.5 \\
\hline 1967 & 2,519 & 84.9 & 561.7 & 39.0 & 153.0 & 114.0 & 4.9 \\
\hline 1968 & 2,183 & 74.0 & 565.0 & 32.0 & 147.0 & 115.0 & 4.9 \\
\hline 1969 & 2,244 & 75.7 & 562.2 & 22.0 & 142.0 & 120.0 & 4.7 \\
\hline 1970 & 2,369 & 79.7 & 560.7 & 22.0 & 143.0 & 121.0 & 4.6 \\
\hline 1971 & 2,633 & 89.1 & 564.0 & 31.0 & 162.0 & 131.0 & 4.3 \\
\hline 1972 & 2,215 & 75.3 & 566.6 & 31.0 & 163.0 & 132.0 & 4.3 \\
\hline 1973 & 2,628 & 87.2 & 553.0 & 37.0 & 170.0 & 133.0 & 4.2 \\
\hline 1974 & 2,282 & 73.9 & 539.7 & 35.0 & 161.0 & 126.0 & 4.3 \\
\hline 1975 & 2,308 & 74.4 & 537.3 & 42.0 & 168.0 & 126.0 & 4.3 \\
\hline 1976 & 2,521 & 79.6 & 526.2 & 50.0 & 176.0 & 126.0 & 4.2 \\
\hline 1977 & 2,782 & 84.2 & 504.4 & 47.0 & 167.0 & 120.0 & 4.2 \\
\hline 1978 & 2,306 & 75.6 & 546.3 & 42.0 & 162.0 & 120.0 & 4.6 \\
\hline 1979 & 1,354 & 45.9 & 564.6 & 13.0 & 134.0 & 121.0 & 4.7 \\
\hline 1980 & 1,955 & 62.9 & 536.3 & 21.0 & 146.0 & 125.0 & 4.3 \\
\hline 1981 & 2,299 & 73.9 & 537.7 & 26.0 & 144.0 & 118.0 & 4.5 \\
\hline 1982 & 3,707 & 108.1 & 486.0 & 71.0 & 180.0 & 109.0 & 4.5 \\
\hline 1983 & 407 & 12.1 & 495.0 & 61.0 & 160.0 & 99.0 & 5.0 \\
\hline 1984 & 2,673 & 96.9 & 604.0 & 75.0 & 201.0 & 126.0 & 4.8 \\
\hline 1985 & 1,919 & 68.5 & 595.0 & 55.0 & 179.0 & 124.0 & 4.8 \\
\hline 1986 & 1,598 & 54.9 & 573.0 & 25.0 & 144.0 & 119.0 & 4.8 \\
\hline 1987 & 2,753 & 97.3 & 589.0 & 66.0 & 187.0 & 121.0 & 4.9 \\
\hline 1988 & 2,187 & 75.4 & 574.0 & 60.0 & 192.0 & 132.0 & 4.4 \\
\hline 1989 & 2,864 & 97.8 & 569.0 & 73.0 & 197.0 & 124.0 & 4.6 \\
\hline 1990 & 2,072 & 68.6 & 552.0 & 70.0 & 196.0 & 126.0 & 4.4 \\
\hline 1991 & 1,488 & 50.4 & 565.0 & 55.0 & 180.0 & 125.0 & 4.5 \\
\hline
\end{tabular}

NOTE: Well was completed March 1960; initial water level: $+34 \mathrm{ft}$ artesian pressure; surface elevation $5,622 \mathrm{ft}$. Well was out of service in 1992; the well was and pump were transferred to San Ildefonso Pueblo in 1992. The water level in 1993 was $+7.5 \mathrm{ft}$ artesian pressure. 
Well LA-2

\begin{tabular}{|c|c|c|c|c|c|c|c|}
\hline \multirow[b]{2}{*}{ Year } & \multirow[b]{2}{*}{$\begin{array}{c}\text { Pump } \\
\text { Time } \\
\text { (h) }\end{array}$} & \multirow[b]{2}{*}{$\begin{array}{l}\text { Production } \\
\left(10^{6} \text { gal. }\right)\end{array}$} & \multirow[b]{2}{*}{$\begin{array}{c}\text { Pump } \\
\text { Rate } \\
\text { (gpm) }\end{array}$} & \multicolumn{2}{|c|}{ Water Level } & \multirow[b]{2}{*}{$\begin{array}{l}\text { Drawdown } \\
\text { (ft) }\end{array}$} & \multirow[b]{2}{*}{$\begin{array}{r}\text { Specific } \\
\text { Capacity } \\
\text { (gpm/ft) }\end{array}$} \\
\hline & & & & $\begin{array}{c}\text { Nonpumping } \\
\text { (ft) }\end{array}$ & $\begin{array}{c}\text { Pumping } \\
\text { (ft) }\end{array}$ & & \\
\hline$\overline{1947}$ & 963 & 27.6 & 477.7 & - & - & - & - \\
\hline 1948 & 3,659 & 59.3 & 270.1 & - & - & - & - \\
\hline 1949 & 1,654 & 41.8 & 421.2 & - & - & - & - \\
\hline 1950 & 614 & 15.6 & 423.5 & 59.0 & 285.0 & 226.0 & 1.9 \\
\hline 1951 & 2,415 & 57.7 & 398.2 & 111.0 & 305.0 & 194.0 & 2.1 \\
\hline 1952 & 1,980 & 46.3 & 389.7 & 101.0 & 300.0 & 199.0 & 2.0 \\
\hline 1953 & 2,201 & 47.2 & 357.4 & 100.0 & 301.0 & 201.0 & 1.8 \\
\hline 1954 & 2,601 & 56.8 & 364.0 & 116.0 & - & - & - \\
\hline 1955 & 2,223 & 49.4 & 370.4 & 110.0 & - & - & - \\
\hline 1956 & 1,805 & 44.2 & 408.1 & 84.0 & - & - & - \\
\hline 1957 & 1,066 & 29.6 & 462.8 & 53.0 & 277.0 & 224.0 & 2.1 \\
\hline 1958 & 1,166 & 31.1 & 444.5 & 60.0 & 270.0 & 210.0 & 2.1 \\
\hline 1959 & 1,599 & 40.7 & 424.2 & 71.0 & 303.0 & 232.0 & 1.8 \\
\hline 1960 & 2,169 & 51.6 & 396.5 & 76.0 & 305.0 & 229.0 & 1.7 \\
\hline 1961 & 2,149 & 44.4 & 344.3 & 101.0 & 313.0 & 212.0 & 1.6 \\
\hline 1962 & 1,823 & 35.7 & 326.4 & 111.0 & 314.0 & 203.0 & 1.6 \\
\hline 1963 & 1,999 & 40.7 & 339.3 & 127.0 & 332.0 & 205.0 & 1.7 \\
\hline 1964 & 1,924 & 34.2 & 296.3 & 137.0 & 347.0 & 210.0 & 1.4 \\
\hline 1965 & 1,911 & 39.8 & 347.1 & 121.0 & 330.0 & 209.0 & 1.7 \\
\hline 1966 & 1,070 & 21.4 & 333.3 & 108.0 & 340.0 & 232.0 & 1.4 \\
\hline 1967 & 238 & 4.9 & 343.1 & 78.0 & 304.0 & 226.0 & 1.5 \\
\hline 1968 & 502 & 11.3 & 375.2 & 64.0 & 305.0 & 241.0 & 1.6 \\
\hline 1969 & 155 & 3.8 & 408.6 & 50.0 & 297.0 & 247.0 & 1.7 \\
\hline 1970 & 341 & 7.2 & 351.9 & 59.0 & 310.0 & 251.0 & 1.4 \\
\hline 1971 & 1,787 & 31.8 & 296.6 & 88.0 & 318.0 & 230.0 & 1.3 \\
\hline 1972 & 2,189 & 39.3 & 299.2 & 96.0 & 322.0 & 226.0 & 1.3 \\
\hline 1973 & 2,625 & 46.7 & 296.5 & 106.0 & 334.0 & 228.0 & 1.3 \\
\hline 1974 & 2,033 & 36.8 & 301.7 & 109.0 & 325.0 & 216.0 & 1.4 \\
\hline 1975 & 2,310 & 40.2 & 290.0 & 103.0 & 320.0 & 217.0 & 1.3 \\
\hline 1976 & 2,488 & 39.9 & 267.3 & 113.0 & 322.0 & 209.0 & 1.3 \\
\hline 1977 & 2,775 & 42.5 & 255.3 & 118.0 & 314.0 & 196.0 & 1.3 \\
\hline 1978 & 2,299 & 39.5 & 286.4 & 112.0 & 338.0 & 226.0 & 1.3 \\
\hline 1979 & 1,353 & 26.2 & 323.0 & 75.0 & 316.0 & 241.0 & 1.3 \\
\hline 1980 & 1,960 & 33.8 & 287.4 & 84.0 & 318.0 & 234.0 & 1.2 \\
\hline 1981 & 1,991 & 34.4 & 300.0 & 94.0 & 336.0 & 242.0 & 1.2 \\
\hline 1982 & 3,174 & 51.2 & 269.0 & 161.0 & 348.0 & 187.0 & 1.4 \\
\hline 1983 & 2,752 & 54.5 & 330.0 & 121.0 & 321.0 & 200.0 & 1.6 \\
\hline 1984 & 2,753 & 53.7 & 325.0 & 130.0 & 323.0 & 193.0 & 1.7 \\
\hline 1985 & 2,027 & 37.1 & 305.0 & 112.0 & 291.0 & 179.0 & 1.7 \\
\hline 1986 & 1,289 & 24.1 & 312.0 & 74.0 & 252.0 & 178.0 & 1.8 \\
\hline 1987 & 2,619 & 39.6 & 252.0 & 129.0 & 319.0 & 190.0 & 1.3 \\
\hline 1988 & 1,936 & 33.0 & 284.0 & 117.0 & 296.0 & 179.0 & 1.6 \\
\hline 1989 & 2,647 & 43.2 & 272.0 & 141.0 & 329.0 & 188.0 & 1.4 \\
\hline 1990 & 2,399 & 40.3 & 280.0 & 134.0 & 330.0 & 196.0 & 1.4 \\
\hline 1991 & 1,705 & 32.7 & 320.0 & 123.0 & 333.0 & 210.0 & 1.5 \\
\hline 1992 & - & 13.4 & - & - & - & - & - \\
\hline 1993 & - & 3.6 & - & - & - & - & - \\
\hline
\end{tabular}

NOTE: Well was completed December 1946; initial water level: flowing; surface elevation 5,651 ft. In 1992 the well was out of service to supply water to Los Alamos; 1992 production was for road construction; the well and pump were transferred to San Ildefonso Pueblo in 1992. 
Well LA-3

\begin{tabular}{|c|c|c|c|c|c|c|c|}
\hline \multirow[b]{2}{*}{ Year } & \multirow{2}{*}{$\begin{array}{c}\text { Pump } \\
\text { Time } \\
\text { (h) }\end{array}$} & \multirow[b]{2}{*}{$\begin{array}{l}\text { Production } \\
\left(10^{6} \text { gal. }\right)\end{array}$} & \multirow{2}{*}{$\begin{array}{c}\text { Pump } \\
\text { Rate } \\
\text { (gpm) }\end{array}$} & \multicolumn{2}{|c|}{ Water Level } & \multirow[b]{2}{*}{$\begin{array}{l}\text { Drawdown } \\
\text { (ft) }\end{array}$} & \multirow{2}{*}{$\begin{array}{r}\text { Specific } \\
\text { Capacity } \\
\text { (gpm/ft) }\end{array}$} \\
\hline & & & & $\begin{array}{l}\text { Nonpumping } \\
\text { (ft) }\end{array}$ & $\begin{array}{c}\text { Pumping } \\
\text { (ft) }\end{array}$ & & \\
\hline 1947 & 1,476 & 64.9 & 732.8 & - & - & - & - \\
\hline 1948 & 3,647 & 82.5 & 377.0 & - & - & - & - \\
\hline 1949 & 1,505 & 41.7 & 461.8 & - & - & - & - \\
\hline 1950 & 2,793 & 57.8 & 344.9 & 97.0 & 231.0 & 134.0 & 2.6 \\
\hline 1951 & 3,554 & 66.9 & 313.7 & 116.0 & 233.0 & 117.0 & 2.7 \\
\hline 1952 & 2,514 & 58.6 & 388.5 & 94.0 & 218.0 & 124.0 & 3.1 \\
\hline 1953 & 3,104 & 69.7 & 374.2 & 103.0 & 229.0 & 126.0 & 3.0 \\
\hline 1954 & 2,595 & 57.3 & 368.0 & 101.0 & 225.0 & 124.0 & 3.0 \\
\hline 1955 & 2,195 & 48.7 & 369.8 & 91.0 & 226.0 & 135.0 & 2.7 \\
\hline 1956 & 1,849 & 42.1 & 379.5 & 74.0 & 222.0 & 148.0 & 2.6 \\
\hline 1957 & 1,080 & 26.1 & 402.8 & 56.0 & 219.0 & 163.0 & 2.5 \\
\hline 1958 & 1,612 & 33.6 & 347.4 & 49.0 & 225.0 & 176.0 & 2.0 \\
\hline 1959 & 1,821 & 35.0 & 320.3 & 54.0 & 231.0 & 177.0 & 1.8 \\
\hline 1960 & 2,174 & 38.4 & 294.4 & 68.0 & 230.0 & 162.0 & 1.8 \\
\hline 1961 & 1,939 & 34.7 & 298.3 & 85.0 & 189.0 & 104.0 & 2.9 \\
\hline 1962 & 2,361 & 45.4 & 320.5 & 93.0 & 192.0 & 99.0 & 3.2 \\
\hline 1963 & 2,128 & 42.5 & 332.9 & 81.0 & 197.0 & 116.0 & 2.9 \\
\hline 1964 & 2,574 & 50.4 & 326.3 & 104.0 & 217.0 & 113.0 & 2.9 \\
\hline 1965 & 1,961 & 43.3 & 368.9 & 79.0 & 220.0 & 141.0 & 2.6 \\
\hline 1966 & 2,236 & 46.1 & 343.6 & 81.0 & 219.0 & 138.0 & 2.5 \\
\hline 1967 & 2,274 & 47.4 & 347.4 & 86.0 & 218.0 & 132.0 & 2.6 \\
\hline 1968 & 2,127 & 42.7 & 334.6 & 82.0 & 251.0 & 169.0 & 2.0 \\
\hline 1969 & 2,072 & 40.1 & 322.6 & 58.0 & 246.0 & 188.0 & 1.7 \\
\hline 1970 & 2,303 & 44.0 & 318.4 & 55.0 & 241.0 & 186.0 & 1.7 \\
\hline 1971 & 2,556 & 45.4 & 296.0 & 77.0 & 250.0 & 173.0 & 1.7 \\
\hline 1972 & 2,205 & 39.7 & 300.1 & 73.0 & 251.0 & 178.0 & 1.7 \\
\hline 1973 & 977 & 20.3 & 346.3 & 65.0 & 248.0 & 183.0 & 1.9 \\
\hline 1974 & 2,291 & 43.5 & 316.5 & 73.0 & 244.0 & 171.0 & 1.9 \\
\hline 1975 & 2,306 & 43.3 & 313.0 & 80.0 & 253.0 & 173.0 & 1.8 \\
\hline 1976 & 2,474 & 42.3 & 285.0 & 88.0 & 260.0 & 172.0 & 1.7 \\
\hline 1977 & 2,779 & 47.3 & 283.7 & 89.0 & 248.0 & 159.0 & 1.8 \\
\hline 1978 & 2,308 & 42.4 & 306.4 & 87.0 & 250.0 & 163.0 & 1.9 \\
\hline 1979 & 1,343 & 28.1 & 348.1 & 58.0 & 243.0 & 185.0 & 1.9 \\
\hline 1980 & 1,952 & 35.1 & 299.9 & 61.0 & 237.0 & 176.0 & 1.7 \\
\hline 1981 & 2,297 & 41.5 & 301.1 & 70.0 & 240.0 & 170.0 & 1.8 \\
\hline 1982 & 3,691 & 54.9 & 247.0 & 118.0 & 246.0 & 128.0 & 1.9 \\
\hline 1983 & 949 & 14.7 & 258.0 & 89.0 & 203.0 & 129.0 & 2.0 \\
\hline 1984 & 838 & 16.6 & 329.0 & 142.0 & 301.0 & 159.0 & 2.0 \\
\hline 1985 & 2,078 & 41.9 & 336.0 & 104.0 & 280.0 & 176.0 & 1.9 \\
\hline 1986 & 1,328 & 26.9 & 338.0 & 88.0 & 255.0 & 167.0 & 2.0 \\
\hline 1987 & 2,710 & 50.9 & 313.0 & 118.0 & 289.0 & 171.0 & 1.8 \\
\hline 1988 & 2,130 & 40.1 & 313.0 & 119.0 & 272.0 & 153.0 & 2.0 \\
\hline 1989 & 2,808 & 51.9 & 308.0 & 122.0 & 298.0 & 176.0 & 1.8 \\
\hline 1990 & 2,461 & 44.6 & 302.0 & 122.0 & 295.0 & 173.0 & 1.8 \\
\hline 1991 & 1,398 & 23.4 & 278.0 & 112.0 & 284.0 & 172.0 & 1.6 \\
\hline
\end{tabular}

NOTE: Well was completed May 1947; initial water level: flowing; surface elevation 5,672 ft.

Air line and recorder were removed in late 1991; water level on March 12, 1992 was $39.55 \mathrm{ft}$ below brass valve. Well was out of service in 1992; the facility was demolished in 1992; well was transferred to San Ildefonso in 1992 and was plugged in 1993. 
Well LA-4

\begin{tabular}{|c|c|c|c|c|c|c|c|}
\hline \multirow[b]{2}{*}{ Year } & \multirow[b]{2}{*}{$\begin{array}{l}\text { Pump } \\
\text { Time } \\
\text { (h) }\end{array}$} & \multirow[b]{2}{*}{$\begin{array}{l}\text { Production } \\
\left(10^{6} \text { gal. }\right)\end{array}$} & \multirow[b]{2}{*}{$\begin{array}{l}\text { Pump } \\
\text { Rate } \\
\text { (gpm) }\end{array}$} & \multicolumn{2}{|c|}{ Water Level } & \multirow[b]{2}{*}{$\begin{array}{l}\text { Drawdown } \\
\text { (ft) }\end{array}$} & \multirow[b]{2}{*}{$\begin{array}{l}\text { Specific } \\
\text { Capacity } \\
\text { (gpm/ft) }\end{array}$} \\
\hline & & & & $\begin{array}{c}\text { Nonpumping } \\
\text { (ft) }\end{array}$ & $\begin{array}{c}\text { Pumping } \\
\text { (ft) }\end{array}$ & & \\
\hline$\overline{1948}$ & 1,570 & 42.7 & 453.3 & - & - & - & - \\
\hline 1949 & 940 & 37.5 & 664.9 & - & - & - & - \\
\hline 1950 & 4,350 & 164.9 & 631.8 & 278.0 & 353.0 & 75.0 & 8.4 \\
\hline 1951 & 4,909 & 173.6 & 589.4 & 285.0 & 357.0 & 72.0 & 8.2 \\
\hline 1952 & 3,429 & 119.6 & 581.3 & 267.0 & 339.0 & 72.0 & 8.1 \\
\hline 1953 & 3,034 & 109.1 & 599.3 & 264.0 & 335.0 & 71.0 & 8.4 \\
\hline 1954 & 2,133 & 78.2 & 611.0 & 255.0 & 329.0 & 74.0 & 8.3 \\
\hline 1955 & 2,647 & 94.5 & 595.0 & 268.0 & 341.0 & 73.0 & 8.2 \\
\hline 1956 & 3,402 & 120.0 & 588.9 & 273.0 & 346.0 & 73.0 & 8.1 \\
\hline 1957 & 2,844 & 105.4 & 617.7 & 270.0 & 345.0 & 75.0 & 8.2 \\
\hline 1958 & 2,973 & 110.3 & 618.3 & 270.0 & 342.0 & 72.0 & 8.6 \\
\hline 1959 & 3,084 & 113.5 & 613.4 & 275.0 & 346.0 & 71.0 & 8.6 \\
\hline 1960 & 4,084 & 145.6 & 594.2 & 296.0 & 365.0 & 69.0 & 8.6 \\
\hline 1961 & 3,687 & 129.7 & 586.3 & 296.0 & 365.0 & 69.0 & 8.5 \\
\hline 1962 & 3,688 & 129.3 & 584.3 & 286.0 & 359.0 & 73.0 & 8.0 \\
\hline 1963 & 3,718 & 130.5 & 585.0 & 280.0 & 351.0 & 71.0 & 8.2 \\
\hline 1964 & 4,500 & 155.0 & 574.1 & 291.0 & 361.0 & 70.0 & 8.2 \\
\hline 1965 & 3,110 & 111.4 & 597.0 & 279.0 & 349.0 & 70.0 & 8.5 \\
\hline 1966 & 3,279 & 115.6 & 587.6 & 285.0 & 356.0 & 71.0 & 8.3 \\
\hline 1967 & 2,127 & 77.1 & 604.1 & 278.0 & 350.0 & 72.0 & 8.4 \\
\hline 1968 & 2,276 & 81.7 & 598.3 & 280.0 & 351.0 & 71.0 & 8.4 \\
\hline 1969 & 1,694 & 61.8 & 608.0 & 282.0 & 358.0 & 76.0 & 8.0 \\
\hline 1970 & 2,333 & 83.5 & 596.5 & 286.0 & 363.0 & 77.0 & 7.7 \\
\hline 1971 & 2,519 & 89.0 & 588.9 & 287.0 & 373.0 & 86.0 & 6.8 \\
\hline 1972 & 2,322 & 82.6 & 592.9 & 282.0 & 367.0 & 85.0 & 7.0 \\
\hline 1973 & 2,616 & 92.4 & 588.7 & 294.0 & 377.0 & 83.0 & 7.1 \\
\hline 1974 & 2,306 & 82.2 & 594.1 & 286.0 & 367.0 & 81.0 & 7.3 \\
\hline 1975 & 2,319 & 82.3 & 591.5 & 272.0 & 355.0 & 83.0 & 7.1 \\
\hline 1976 & 2,802 & 98.2 & 584.1 & 277.0 & 373.0 & 96.0 & 6.1 \\
\hline 1977 & 2,741 & 96.4 & 586.2 & 278.0 & 374.0 & 96.0 & 6.1 \\
\hline 1978 & 2,248 & 80.1 & 594.2 & 271.0 & 368.0 & 97.0 & 6.1 \\
\hline 1979 & 2,964 & 104.6 & 587.9 & 280.0 & 376.0 & 96.0 & 6.1 \\
\hline 1980 & 3,322 & 115.3 & 578.5 & 284.0 & 385.0 & 101.0 & 5.7 \\
\hline 1981 & 2,573 & 89.4 & 579.1 & 289.0 & 393.0 & 104.0 & 5.6 \\
\hline 1982 & 0 & 0 & 0 & - & - & - & - \\
\hline 1983 & 1,840 & 61.5 & 577.0 & 287.0 & 392.0 & 105.0 & 5.3 \\
\hline 1984 & 2,695 & 87.1 & 539.0 & 290.0 & 383.0 & 93.0 & 5.8 \\
\hline 1985 & 2,667 & 86.4 & 540.0 & 292.0 & 378.0 & 86.0 & 6.3 \\
\hline 1986 & 1,172 & 38.8 & 552.0 & 284.0 & 377.0 & 93.0 & 5.9 \\
\hline 1987 & 38 & 1.6 & - & 269.0 & 357.0 & 88.0 & - \\
\hline
\end{tabular}

NOTE: Well was completed August 1948; initial water level $189 \mathrm{ft}$; surface elevation 5,975 ft.

Well was out of service in 1988. Air line and recorder were removed in 1990 . Water level was $244.4 \mathrm{ft}$ on June 22, 1990, and $244.2 \mathrm{ft}$ on March 11, 1991; both measurements were below top of brass valve. Facilities demolished in 1992 and well was transferred to San Ildefonso Pueblo in 1992. 
Well LA-5

\begin{tabular}{|c|c|c|c|c|c|c|c|}
\hline \multirow[b]{2}{*}{ Year } & \multirow{2}{*}{$\begin{array}{l}\text { Pump } \\
\text { Time } \\
\text { (h) }\end{array}$} & \multirow[b]{2}{*}{$\begin{array}{l}\text { Production } \\
\left(10^{6} \text { gal. }\right)\end{array}$} & \multirow{2}{*}{$\begin{array}{c}\text { Pump } \\
\text { Rate } \\
\text { (gpm) }\end{array}$} & \multicolumn{2}{|c|}{ Water Level } & \multirow[b]{2}{*}{$\begin{array}{l}\text { Drawdown } \\
\text { (ft) }\end{array}$} & \multirow{2}{*}{$\begin{array}{l}\text { Specific } \\
\text { Capacity } \\
(\mathrm{gpm} / \mathrm{ft})\end{array}$} \\
\hline & & & & $\begin{array}{c}\text { Nonpumping } \\
\text { (ft) }\end{array}$ & $\begin{array}{c}\text { Pumping } \\
\text { (ft) }\end{array}$ & & \\
\hline 1948 & 1,171 & 40.4 & 575.0 & - & - & - & - \\
\hline 1949 & 1,763 & 58.5 & 553.0 & - & - & - & - \\
\hline 1950 & 4,052 & 130.1 & 535.1 & 131.0 & 254.0 & 123.0 & 4.4 \\
\hline 1951 & 6004 & 187.4 & 520.2 & 162.0 & 272.0 & 110.0 & 4.7 \\
\hline 1952 & 3,425 & 109.6 & 533.3 & 147.0 & 259.0 & 112.0 & 4.8 \\
\hline 1953 & 3,278 & 103.9 & 528.3 & 141.0 & 257.0 & 116.0 & 4.6 \\
\hline 1954 & 2,546 & 80.1 & 524.4 & 137.0 & 259.0 & 122.0 & 4.3 \\
\hline 1955 & 3,158 & 97.3 & 513.5 & 145.0 & 267.0 & 122.0 & 4.2 \\
\hline 1956 & 3,476 & 104.5 & 501.1 & 150.0 & 276.0 & 126.0 & 4.0 \\
\hline 1957 & 2,868 & 86.0 & 499.8 & 150.0 & 277.0 & 127.0 & 3.9 \\
\hline 1958 & 3,009 & 89.9 & 498.0 & 151.0 & 277.0 & 126.0 & 4.0 \\
\hline 1959 & 3,088 & 93.5 & 504.6 & 155.0 & 280.0 & 125.0 & 4.0 \\
\hline 1960 & 4,088 & 119.1 & 485.6 & 168.0 & 288.0 & 120.0 & 4.0 \\
\hline 1961 & 3,534 & 100.3 & 473.0 & 165.0 & 288.0 & 123.0 & 3.8 \\
\hline 1962 & 3,735 & 107.7 & 480.6 & 172.0 & - & - & - \\
\hline 1963 & 3,726 & 105.0 & 469.7 & 171.0 & - & - & - \\
\hline 1964 & 4,236 & 118.8 & 467.4 & 184.0 & - & - & - \\
\hline 1965 & 1,740 & 50.5 & 483.7 & 180.0 & - & - & - \\
\hline 1966 & 2,817 & 79.3 & 469.2 & 180.0 & - & - & - \\
\hline 1967 & 2,533 & 73.7 & 484.9 & 168.0 & - & - & - \\
\hline 1968 & 2,233 & 63.3 & 472.5 & 161.0 & 300.0 & 139.0 & 3.4 \\
\hline 1969 & 2,402 & 68.5 & 475.3 & 161.0 & 298.0 & 137.0 & 3.5 \\
\hline 1970 & 2,353 & 66.1 & 468.2 & 157.0 & 300.0 & 143.0 & 3.3 \\
\hline 1971 & 2,659 & 74.4 & 466.3 & 155.0 & 302.0 & 147.0 & 3.2 \\
\hline 1972 & 2,301 & 64.4 & 466.5 & 153.0 & 304.0 & 151.0 & 3.1 \\
\hline 1973 & 2,476 & 68.3 & 459.7 & 156.0 & 308.0 & 152.0 & 3.0 \\
\hline 1974 & 1,903 & 52.5 & 459.8 & 154.0 & 306.0 & 152.0 & 3.0 \\
\hline 1975 & 2,318 & 63.9 & 459.4 & 149.0 & 309.0 & 160.0 & 2.9 \\
\hline 1976 & 2,799 & 77.6 & 462.1 & 150.0 & 310.0 & 160.0 & 2.9 \\
\hline 1977 & 2,665 & 74.8 & 467.8 & 147.0 & 303.0 & 156.0 & 3.0 \\
\hline 1978 & 2,274 & 64.9 & 475.8 & 145.0 & 299.0 & 154.0 & 3.1 \\
\hline 1979 & 2,964 & 84.0 & 472.4 & 149.0 & 301.0 & 152.0 & 3.1 \\
\hline 1980 & 3,316 & 92.2 & 463.6 & 153.0 & 300.0 & 147.0 & 3.2 \\
\hline 1981 & 3,523 & 96.5 & 456.5 & 158.0 & 304.0 & 146.0 & 3.1 \\
\hline 1982 & 3,654 & 102.3 & 467.0 & 168.0 & 299.0 & 136.0 & 3.4 \\
\hline 1983 & 2,842 & 78.1 & 458.0 & 154.0 & 295.0 & 141.0 & 3.2 \\
\hline 1984 & 2,889 & 72.1 & 416.0 & 156.0 & 281.0 & 125.0 & 3.1 \\
\hline 1985 & 2,153 & 55.8 & 432.0 & 174.0 & 308.0 & 134.0 & 3.2 \\
\hline 1986 & 1,376 & 34.6 & 419.0 & 168.0 & 310.0 & 142.0 & 2.9 \\
\hline 1987 & 1,148 & 27.9 & 405.0 & 167.0 & 314.0 & 147.0 & 2.8 \\
\hline 1988 & 351 & 9.9 & 406.0 & - & - & - & - \\
\hline 1989 & 1,074 & 26.5 & 411.0 & - & - & - & - \\
\hline 1990 & 1,388 & 33.3 & 400.0 & - & - & - & - \\
\hline 1991 & 783 & 18.5 & 394 & - & - & - & - \\
\hline
\end{tabular}

NOTE: Well was completed September 1948; initial water level $71 \mathrm{ft}$; surface elevation 5,840 ft. Air line and recorder were removed in late 1991; water level on December 4, 1991 (TV log), was $158 \mathrm{ft}$ below top of pump base $(5,856.5 \mathrm{ft})$. Well was out of service in 1992; well and pump were transferred to San Ildefonso Pueblo in 1992. 


\section{Well LA-6}

\begin{tabular}{|c|c|c|c|c|c|c|c|}
\hline \multirow[b]{2}{*}{ Year } & \multirow[b]{2}{*}{$\begin{array}{c}\text { Pump } \\
\text { Time } \\
\text { (h) }\end{array}$} & \multirow[b]{2}{*}{$\begin{array}{l}\text { Production } \\
\left(1^{6} \text { gal. }\right)\end{array}$} & \multirow[b]{2}{*}{$\begin{array}{c}\text { Pump } \\
\text { Rate } \\
\text { (gpm) }\end{array}$} & \multicolumn{2}{|c|}{ Water Level } & \multirow[b]{2}{*}{$\begin{array}{l}\text { Drawdown } \\
\text { (ft) }\end{array}$} & \multirow[b]{2}{*}{$\begin{array}{l}\text { Specific } \\
\text { Capacity } \\
(\mathrm{gpm} / \mathrm{ft})\end{array}$} \\
\hline & & & & $\begin{array}{l}\text { Nonpumping } \\
\text { (ft) }\end{array}$ & $\begin{array}{l}\text { Pumping } \\
\text { (ft) }\end{array}$ & & \\
\hline$\overline{1948}$ & 116 & 4.9 & 704.0 & - & - & - & - \\
\hline 1949 & 2,451 & 95.8 & 651.4 & - & - & - & - \\
\hline 1950 & 4,490 & 167.9 & 623.2 & 83.0 & 136.0 & 53.0 & 11.8 \\
\hline 1951 & 5882 & 201.6 & 571.2 & 115.0 & 160.0 & 45.0 & 12.7 \\
\hline 1952 & 3,168 & 110.3 & 580.3 & 108.0 & 151.0 & 43.0 & 13.5 \\
\hline 1953 & 3,177 & 113.8 & 597.0 & 95.0 & 139.0 & 44.0 & 13.6 \\
\hline 1954 & 2,894 & 107.1 & 616.8 & 92.0 & 135.0 & 43.0 & 14.3 \\
\hline 1955 & 2,911 & 108.0 & 618.3 & 97.0 & 140.0 & 43.0 & 14.4 \\
\hline 1956 & 3,438 & 125.8 & 609.9 & 106.0 & 149.0 & 43.0 & 14.2 \\
\hline 1957 & 2,833 & 102.4 & 602.4 & 107.0 & 152.0 & 45.0 & 13.4 \\
\hline 1958 & 2,957 & 106.9 & 602.5 & 108.0 & 131.0 & 43.0 & 14.0 \\
\hline 1959 & 3,096 & 108.3 & 583.0 & 115.0 & 158.0 & 43.0 & 13.6 \\
\hline 1960 & 4,084 & 138.6 & 565.6 & 130.0 & 172.0 & 42.0 & 13.5 \\
\hline 1961 & 3,284 & 112.5 & 571.0 & 129.0 & 171.0 & 42.0 & 13.6 \\
\hline 1962 & 3,886 & 129.4 & 555.0 & 135.0 & 175.0 & 40.0 & 13.9 \\
\hline 1963 & 2,953 & 102.9 & 580.8 & 125.0 & 171.0 & 46.0 & 12.6 \\
\hline 1964 & 4,244 & 138.3 & 543.1 & 132.0 & 172.0 & 40.0 & 13.6 \\
\hline 1965 & 3,145 & 103.8 & 550.1 & 120.0 & 160.0 & 40.0 & 13.8 \\
\hline 1966 & 3,173 & 104.0 & 546.3 & 129.0 & 169.0 & 40.0 & 13.7 \\
\hline 1967 & 2,511 & 85.4 & 566.8 & 118.0 & 158.0 & 40.0 & 14.2 \\
\hline 1968 & 2,111 & 71.6 & 565.3 & 109.0 & 150.0 & 41.0 & 13.8 \\
\hline 1969 & 2,402 & 81.6 & 566.2 & 109.0 & 151.0 & 42.0 & 13.5 \\
\hline 1970 & 2,337 & 79.1 & 564.1 & 106.0 & 149.0 & 43.0 & 13.1 \\
\hline 1971 & 2,472 & 82.5 & 556.2 & 119.0 & 160.0 & 41.0 & 13.6 \\
\hline 1972 & 2,317 & 79.2 & 569.7 & 117.0 & 155.0 & 38.0 & 15.0 \\
\hline 1973 & 2,638 & 90.6 & 572.4 & 118.4 & 155.0 & 37.0 & 15.5 \\
\hline 1974 & 2,337 & 79.8 & 569.1 & 120.0 & 156.0 & 36.0 & 15.8 \\
\hline 1975 & 1,571 & 51.9 & 550.6 & 113.0 & 151.0 & 38.0 & 14.5 \\
\hline 1976 & 175 & 5.1 & 485.7 & 96.0 & - & - & - \\
\hline 1977 & - & - & - & 82.0 & - & - & - \\
\hline 1978 & 33 & 1.1 & 572.7 & 77.0 & 142.0 & 65.0 & 8.8 \\
\hline 1979 & 6 & 0.2 & 555.6 & 80.0 & 146.0 & 66.0 & 8.4 \\
\hline 1980 & 4 & 0.1 & 520.8 & 82.0 & 142.0 & 60.0 & 8.7 \\
\hline 1981 & 2.3 & 0.08 & 579.8 & 84.0 & 141.0 & 57.0 & 10.2 \\
\hline 1982 & - & - & - & 90.0 & - & - & - \\
\hline 1983 & - & - & - & 81.0 & - & - & - \\
\hline 1984 & - & - & - & 83.0 & - & - & - \\
\hline 1985 & - & - & - & 92.0 & - & - & - \\
\hline 1986 & - & - & - & - & - & - & - \\
\hline 1987 & - & $<0.1$ & - & - & - & - & - \\
\hline 1988 & - & $<0.1$ & - & - & - & - & - \\
\hline 1989 & - & $<0.1$ & - & - & - & - & - \\
\hline 1990 & - & - & - & - & - & - & - \\
\hline
\end{tabular}

NOTE: Well was completed December 1948; initial water level $5 \mathrm{ft}$; surface elevation $5,770 \mathrm{ft}$. Air line and recorder were removed in 1990; water level on May 5, 1990 was $\mathbf{- 8 2 . 5} \mathrm{ft}$ below land surface datum $(5,770 \mathrm{ft})$; on March 11, 1992 it was $98.35 \mathrm{ft}$ below brass valve. Well was out of service in 1977 but has been pumped since that time for quality-of-water samples. The pump was removed in 1990; the facility was demolished in 1991; the well was transferred to San Ildefonso Pueblo in 1992 and plugged in 1993. 
Well G-1

\begin{tabular}{|c|c|c|c|c|c|c|c|}
\hline \multirow[b]{2}{*}{ Year } & \multirow[b]{2}{*}{$\begin{array}{l}\text { Pump } \\
\text { Time } \\
\text { (h) }\end{array}$} & \multirow[b]{2}{*}{$\begin{array}{l}\text { Production } \\
\text { (106 gal.) }\end{array}$} & \multirow[b]{2}{*}{$\begin{array}{c}\text { Pump } \\
\text { Rate } \\
\text { (gpm) }\end{array}$} & \multicolumn{2}{|c|}{ Water Level } & \multirow[b]{2}{*}{$\begin{array}{l}\text { Drawdown } \\
\text { (ft) }\end{array}$} & \multirow[b]{2}{*}{$\begin{array}{r}\text { Specific } \\
\text { Capacity } \\
\text { (gpm/ft) }\end{array}$} \\
\hline & & & & $\begin{array}{c}\text { Nonpumping } \\
\text { (ft) }\end{array}$ & $\begin{array}{l}\text { Pumping } \\
\text { (ft) }\end{array}$ & & \\
\hline 1950 & 0 & 2.80 & 0.0 & 195.0 & - & - & - \\
\hline 1951 & 1,168 & 37.70 & 538.0 & 202.0 & 309.0 & 107.0 & 5.0 \\
\hline 1952 & 2,476 & 75.50 & 508.2 & 213.0 & 295.0 & 82.0 & 6.2 \\
\hline 1953 & 3,275 & 97.30 & 495.2 & 221.0 & 292.0 & 71.0 & 7.0 \\
\hline 1954 & 2,616 & 77.80 & 495.7 & 221.0 & 290.0 & 69.0 & 7.2 \\
\hline 1955 & 2,406 & 70.50 & 448.4 & 226.0 & 295.0 & 69.0 & 7.1 \\
\hline 1956 & 2,958 & 83.20 & 468.8 & 235.0 & 303.0 & 68.0 & 6.9 \\
\hline 1957 & 2,098 & 55.90 & 444.1 & 236.0 & 307.0 & 71.0 & 6.3 \\
\hline 1958 & 2,460 & 68.10 & 461.4 & 238.0 & 308.0 & 70.0 & 6.6 \\
\hline 1959 & 2,952 & 82.40 & 465.2 & 245.0 & 314.0 & 69.0 & 6.7 \\
\hline 1960 & 3,564 & 96.00 & 448.9 & 254.0 & 325.0 & 71.0 & 6.3 \\
\hline 1961 & 4,236 & 112.40 & 442.2 & 260.0 & 333.0 & 73.0 & 6.1 \\
\hline 1962 & 3,431 & 93.60 & 454.7 & 258.0 & 342.0 & 84.0 & 5.4 \\
\hline 1963 & 4,519 & 114.90 & 423.8 & 265.0 & 348.0 & 83.0 & 5.1 \\
\hline 1964 & 4,374 & 113.80 & 433.6 & 269.0 & 352.0 & 83.0 & 5.2 \\
\hline 1965 & 3,530 & 90.70 & 428.2 & 268.0 & 352.0 & 84.0 & 5.1 \\
\hline 1966 & 4,074 & 102.60 & 419.7 & 269.0 & 363.0 & 94.0 & 4.5 \\
\hline 1967 & 2,615 & 69.90 & 445.5 & 266.0 & 362.0 & 96.0 & 4.6 \\
\hline 1968 & 2,996 & 78.90 & 438.9 & 264.0 & 366.0 & 102.0 & 4.3 \\
\hline 1969 & 2,657 & 68.30 & 428.4 & 266.0 & 376.0 & 110.0 & 3.9 \\
\hline 1970 & 2,712 & 64.70 & 397.6 & 264.0 & 377.0 & 113.0 & 3.5 \\
\hline 1971 & 2,908 & 67.90 & 389.2 & 258.0 & 378.0 & 120.0 & 3.2 \\
\hline 1972 & 2,865 & 66.10 & 384.5 & 264.0 & 389.0 & 125.0 & 3.1 \\
\hline 1973 & 2,997 & 67.50 & 375.4 & 271.0 & 403.0 & 132.0 & 2.8 \\
\hline 1974 & 2,767 & 62.30 & 375.3 & 283.0 & 412.0 & 129.0 & 2.9 \\
\hline 1975 & 2,467 & 55.70 & 376.3 & 293.0 & 411.0 & 118.0 & 3.2 \\
\hline 1976 & 2,962 & 65.10 & 366.3 & - & - & - & - \\
\hline 1977 & 2,734 & 57.90 & 353.0 & 275.0 & 426.0 & 151.0 & 2.3 \\
\hline 1978 & 2,656 & 56.00 & 351.4 & 270.0 & 419.0 & 149.0 & 2.4 \\
\hline 1979 & 2,998 & 61.70 & 342.9 & 271.0 & 422.0 & 151.0 & 2.3 \\
\hline 1980 & 3,459 & 68.30 & 329.0 & 273.0 & 428.0 & 155.0 & 2.1 \\
\hline 1981 & 4,427 & 81.60 & 307.2 & 275.0 & 444.0 & 169.0 & 1.8 \\
\hline 1982 & 3,678 & 69.00 & 313.0 & 278.0 & 443.0 & 165.0 & 1.9 \\
\hline 1983 & 2,871 & 52.20 & 303.0 & 272.0 & 443.0 & 171.0 & 1.8 \\
\hline 1984 & 3,804 & 62.80 & 275.0 & 276.0 & 448.0 & 172.0 & 1.5 \\
\hline 1985 & 3,004 & 48.30 & 268.0 & 278.0 & 450.0 & 172.0 & 1.6 \\
\hline 1986 & 2,027 & 30.30 & 249.0 & 279.0 & 450.0 & 171.0 & 1.5 \\
\hline 1987 & 2,070 & 29.20 & 235.0 & 280.0 & 451.0 & $171: 0$ & 1.4 \\
\hline 1988 & 395 & 5.40 & 227.0 & 280.0 & 445.0 & 165.0 & 1.4 \\
\hline 1989 & 2,010 & 26.90 & 223.0 & 282.0 & 451.0 & 169.0 & 1.3 \\
\hline 1990 & 2,121 & 30.80 & 242.0 & 284.0 & 454.0 & 170.0 & 1.4 \\
\hline 1991 & 1,730 & 20.90 & 201.0 & 282.0 & 451.0 & 169.0 & 1.2 \\
\hline 1992 & 1,077 & 12.00 & 186.0 & 283.0 & 439.0 & 156.0 & 1.2 \\
\hline 1993 & 2.5 & 0.03 & 200.0 & 280.0 & - & - & - \\
\hline
\end{tabular}

NOTE: Well was completed July 1950; initial water level $192 \mathrm{ft}$; surface elevation 5,973 ft. 
Well G-1A

\begin{tabular}{|c|c|c|c|c|c|c|c|}
\hline \multirow[b]{2}{*}{ Year } & \multirow{2}{*}{$\begin{array}{c}\text { Pump } \\
\text { Time } \\
\text { (h) }\end{array}$} & \multirow[b]{2}{*}{$\begin{array}{l}\text { Production } \\
\left(1^{6} \text { gal. }\right)\end{array}$} & \multirow{2}{*}{$\begin{array}{c}\text { Pump } \\
\text { Rate } \\
\text { (gpm) }\end{array}$} & \multicolumn{2}{|c|}{ Water Level } & \multirow[b]{2}{*}{$\begin{array}{l}\text { Drawdown } \\
\text { (ft) }\end{array}$} & \multirow[b]{2}{*}{$\begin{array}{l}\text { Specific } \\
\text { Capacity } \\
(\mathrm{gpm} / \mathrm{ft})\end{array}$} \\
\hline & & & & $\begin{array}{l}\text { Nonpumping } \\
\text { (ft) }\end{array}$ & $\begin{array}{c}\text { Pumping } \\
\text { (ft) }\end{array}$ & & \\
\hline 1954 & 108 & 4.6 & 709.0 & - & - & - & - \\
\hline 1955 & 1,531 & 53.0 & 577.0 & 265.0 & 316.0 & 51.0 & 11.3 \\
\hline 1956 & 3,130 & 107.7 & 573.5 & 273.0 & 323.0 & 50.0 & 11.5 \\
\hline 1957 & 2,470 & 87.0 & 587.0 & 274.0 & 327.0 & 53.0 & 11.1 \\
\hline 1958 & 2,670 & 92.5 & 577.4 & 279.0 & 331.0 & 52.0 & 11.1 \\
\hline 1959 & 2,965 & 102.7 & 577.3 & 284.0 & 333.0 & 49.0 & 11.8 \\
\hline 1960 & 3,641 & 122.8 & 562.1 & 291.0 & 342.0 & 51.0 & 11.0 \\
\hline 1961 & 4,297 & 147.3 & 571.3 & 298.0 & 350.0 & 52.0 & 11.0 \\
\hline 1962 & 3,972 & 136.1 & 571.1 & 295.0 & 344.0 & 49.0 & 11.7 \\
\hline 1963 & 4,525 & 149.7 & 551.4 & 301.0 & 350.0 & 49.0 & 11.3 \\
\hline 1964 & 3,852 & 129.3 & 559.4 & 302.0 & 353.0 & 51.0 & 11.0 \\
\hline 1965 & 3,505 & 116.5 & 554.0 & 302.0 & 353.0 & 51.0 & 10.9 \\
\hline 1966 & 3,964 & 133.4 & 560.9 & 306.0 & 355.0 & 49.0 & 11.4 \\
\hline 1967 & 2,720 & 91.3 & 559.4 & 302.0 & 351.0 & 49.0 & 11.4 \\
\hline 1968 & 3,089 & 103.2 & 556.8 & 302.0 & 352.0 & 50.0 & 11.1 \\
\hline 1969 & 2,695 & 90.7 & 560.9 & 303.0 & 356.0 & 53.0 & 10.6 \\
\hline 1970 & 2,772 & 92.5 & 556.2 & 300.0 & 357.0 & 57.0 & 9.8 \\
\hline 1971 & 3,313 & 111.8 & 562.4 & 303.0 & 361.0 & 58.0 & 9.7 \\
\hline 1972 & 2,879 & 94.0 & 544.2 & 302.0 & 361.0 & 59.0 & 9.2 \\
\hline 1973 & 2,760 & 87.9 & 530.8 & 302.0 & 362.0 & 60.0 & 8.8 \\
\hline 1974 & 2,974 & 92.7 & 519.5 & 307.0 & 355.0 & 48.0 & 10.8 \\
\hline 1975 & 2,740 & 85.3 & 518.9 & 304.0 & 351.0 & 47.0 & 11.0 \\
\hline 1976 & 2,983 & 91.6 & 511.8 & 302.0 & 350.0 & 48.0 & 10.7 \\
\hline 1977 & 2,942 & 88.7 & 502.5 & 302.0 & 350.0 & 48.0 & 10.5 \\
\hline 1978 & 2,631 & 77.9 & 493.5 & 300.0 & 345.0 & 45.0 & 11.0 \\
\hline 1979 & 2,974 & 88.0 & 493.9 & 301.0 & 345.0 & 44.0 & 11.0 \\
\hline 1980 & 3,480 & 103.2 & 494.4 & 305.0 & 345.0 & 40.0 & 12.4 \\
\hline 1981 & 4,212 & 131.2 & 519.1 & 307.0 & 347.0 & 40.0 & 13.0 \\
\hline 1982 & 3,618 & 109.7 & 505.0 & 305.0 & 347.0 & 42.0 & 12.0 \\
\hline 1983 & 2,901 & 86.7 & 498.0 & 301.0 & 336.0 & 35.0 & 14.2 \\
\hline 1984 & 3,789 & 113.9 & 501.0 & 302.0 & 345.0 & 43.0 & 11.7 \\
\hline 1985 & 4,430 & 128.4 & 483.0 & 306.0 & 348.0 & 42.0 & 11.5 \\
\hline 1986 & 4,644 & 130.4 & 468.0 & 310.0 & 351.0 & 41.0 & 11.4 \\
\hline 1987 & 4,468 & 122.5 & 457.0 & 320.0 & 362.0 & 42.0 & 10.9 \\
\hline 1988 & 5,016 & 133.5 & 443.0 & 323.0 & 364.0 & 41.0 & 10.8 \\
\hline 1989 & 4,663 & 131.5 & 470.0 & 323.0 & 359.0 & 36.0 & 13.1 \\
\hline 1990 & 4,860 & 145.5 & 499.0 & 322.0 & 362.0 & 40.0 & 12.5 \\
\hline 1991 & 5,120 & 150.2 & 489.0 & 325.0 & 361.0 & 36.0 & 13.6 \\
\hline 1992 & 4,676 & 134.1 & 478.0 & 325.0 & 361.0 & 36.0 & 13.3 \\
\hline 1993 & 3,862 & 108.2 & 467.0 & 321.0 & 355.0 & 34.0 & 13.7 \\
\hline
\end{tabular}

NOTE: Well was completed December 1954; initial water level $250 \mathrm{ft}$; surface elevation $6,014 \mathrm{ft}$. 


\section{Well G-2}

\begin{tabular}{|c|c|c|c|c|c|c|c|}
\hline \multirow[b]{2}{*}{ Year } & \multirow[b]{2}{*}{$\begin{array}{c}\text { Pump } \\
\text { Time } \\
\text { (h) }\end{array}$} & \multirow[b]{2}{*}{$\begin{array}{c}\text { Production } \\
\left(10^{6} \text { gal. }\right)\end{array}$} & \multirow[b]{2}{*}{$\begin{array}{l}\text { Pump } \\
\text { Rate } \\
\text { (gpm) }\end{array}$} & \multicolumn{2}{|c|}{ Water Level } & \multirow[b]{2}{*}{$\begin{array}{l}\text { Drawdown } \\
\text { (ft) }\end{array}$} & \multirow[b]{2}{*}{$\begin{array}{l}\text { Specific } \\
\text { Capacity } \\
\text { (gpm/ft) }\end{array}$} \\
\hline & & & & $\begin{array}{l}\text { Nonpumping } \\
\text { (ft) }\end{array}$ & $\begin{array}{c}\text { Pumping } \\
\text { (ft) }\end{array}$ & & \\
\hline$\overline{1951}$ & 123 & 3.9 & 528.5 & 259.0 & - & - & - \\
\hline 1952 & 2,372 & 78.3 & 550.2 & 279.0 & 327.0 & 48.0 & 11.5 \\
\hline 1953 & 3,254 & 105.6 & 540.9 & 290.0 & 334.0 & 44.0 & 12.3 \\
\hline 1954 & 2,682 & 86.3 & 536.3 & 291.0 & 335.0 & 44.0 & 12.2 \\
\hline 1955 & 2,487 & 78.8 & 528.1 & 299.0 & 345.0 & 46.0 & 11.5 \\
\hline 1956 & 3,109 & 95.8 & 513.6 & 310.0 & 357.0 & 47.0 & 10.9 \\
\hline 1957 & 2,458 & 76.1 & 516.0 & 311.0 & 360.0 & 49.0 & 10.5 \\
\hline 1958 & 2,707 & 80.1 & 493.2 & 315.0 & 361.0 & 46.0 & 10.7 \\
\hline 1959 & 2,938 & 84.6 & 479.9 & 320.0 & 363.0 & 43.0 & 11.2 \\
\hline 1960 & 3,535 & 96.6 & 455.4 & 328.0 & 370.0 & 42.0 & 10.8 \\
\hline 1961 & 3,982 & 105.3 & 440.7 & 336.0 & 375.0 & 39.0 & 11.3 \\
\hline 1962 & 4,076 & 99.8 & 408.1 & 338.0 & 374.0 & 36.0 & 11.3 \\
\hline 1963 & 4,563 & 105.7 & 386.1 & 344.0 & 379.0 & 35.0 & 11.0 \\
\hline 1964 & 4,541 & 105.3 & 386.5 & 346.0 & 380.0 & 34.0 & 11.4 \\
\hline 1965 & 3,535 & 82.6 & 389.4 & 346.0 & 381.0 & 35.0 & 11.1 \\
\hline 1966 & 3,994 & 94.7 & 395.2 & 349.0 & 383.0 & 34.0 & 11.6 \\
\hline 1967 & 2,743 & 67.6 & 410.7 & 344.0 & 379.0 & 35.0 & 11.7 \\
\hline 1968 & 2,732 & 66.5 & 405.7 & 344.0 & 379.0 & 35.0 & 11.6 \\
\hline 1969 & 2,679 & 68.6 & 426.8 & 344.0 & 381.0 & 37.0 & 11.5 \\
\hline 1970 & 2,431 & 62.8 & 430.5 & 343.0 & 381.0 & 38.0 & 11.3 \\
\hline 1971 & 3,420 & 87.4 & 425.9 & 345.0 & 384.0 & 39.0 & 10.9 \\
\hline 1972 & 2,887 & 73.4 & 423.7 & 348.0 & 388.0 & 40.0 & 10.6 \\
\hline 1973 & 2,816 & 72.4 & 428.5 & 344.0 & 385.0 & 41.0 & 10.5 \\
\hline 1974 & 3,056 & 82.0 & 447.2 & 347.0 & 390.0 & 43.0 & 10.4 \\
\hline 1975 & 2,724 & 74.5 & 455.8 & 341.0 & 384.0 & 43.0 & 10.6 \\
\hline 1976 & 2,990 & 81.1 & 452.1 & 344.0 & 388.0 & 44.0 & 10.3 \\
\hline 1977 & 2,981 & 80.4 & 449.5 & 346.0 & 388.0 & 42.0 & 10.7 \\
\hline 1978 & 2,562 & 71.6 & 451.9 & 345.0 & 386.0 & 41.0 & 11.0 \\
\hline 1979 & 2,975 & 80.0 & 448.0 & 347.0 & 388.0 & 41.0 & 11.0 \\
\hline 1980 & 3,478 & 92.4 & 443.0 & 350.0 & 389.0 & 39.0 & 11.4 \\
\hline 1981 & 1,432 & 38.3 & 445.8 & 352.0 & 390.0 & 38.0 & 11.7 \\
\hline 1982 & 2,833 & 25.7 & 476.0 & 352.0 & 399.0 & 47.0 & 10.1 \\
\hline 1983 & 624 & 16.5 & 441.0 & 356.0 & 399.0 & 43.0 & 10.3 \\
\hline 1984 & 2,018 & 43.7 & 361.0 & 358.0 & 385.0 & 27.0 & 13.4 \\
\hline 1985 & 4,339 & 96.6 & 371.0 & 352.0 & 381.0 & 29.0 & 12.8 \\
\hline 1986 & 4,769 & 109.3 & 382.0 & 369.0 & 395.0 & 26.0 & 14.7 \\
\hline 1987 & 4,526 & 109.7 & 404.0 & 366.0 & 399.0 & 33.0 & 12.2 \\
\hline 1988 & 4,836 & 132.8 & 457.0 & 367.0 & 400.0 & 33.0 & 13.9 \\
\hline 1989 & 4,820 & 133.9 & 463.0 & 375.0 & 408.0 & 33.0 & 14.0 \\
\hline 1990 & 5,060 & 134.5 & 443.0 & 374.0 & 407.0 & 33.0 & 13.4 \\
\hline 1991 & 4,792 & 123.3 & 428.0 & 369.0 & 401.0 & 32.0 & 13.4 \\
\hline 1992 & 5,075 & 129.0 & 424.0 & 370.0 & 401.0 & 31.0 & 13.7 \\
\hline 1993 & 3,871 & 97.1 & 418.0 & 368.0 & 399.0 & 31.0 & 13.5 \\
\hline
\end{tabular}

NOTE: Well was completed August 1951; initial water level $259 \mathrm{ft}$; surface elevation $6,056 \mathrm{ft}$. 
Well G-3

\begin{tabular}{|c|c|c|c|c|c|c|c|}
\hline \multirow[b]{2}{*}{ Year } & \multirow[b]{2}{*}{$\begin{array}{c}\text { Pump } \\
\text { Time } \\
\text { (h) }\end{array}$} & \multirow[b]{2}{*}{$\begin{array}{c}\text { Production } \\
\left(10^{6} \text { gal. }\right)\end{array}$} & \multirow[b]{2}{*}{$\begin{array}{c}\text { Pump } \\
\text { Rate } \\
\text { (gpm) }\end{array}$} & \multicolumn{2}{|c|}{ Water Level } & \multirow[b]{2}{*}{$\begin{array}{l}\text { Drawdown } \\
\text { (ft) }\end{array}$} & \multirow[b]{2}{*}{$\begin{array}{l}\text { Specific } \\
\text { Capacity } \\
(\mathrm{gpm} / \mathrm{ft})\end{array}$} \\
\hline & & & & $\begin{array}{c}\text { Nonpumping } \\
\text { (ft) }\end{array}$ & $\begin{array}{c}\text { Pumping } \\
\text { (ft) }\end{array}$ & & \\
\hline 1951 & 192 & 7.3 & 633.7 & 281.0 & - & - & - \\
\hline 1952 & 2,379 & 65.4 & 458.2 & 310.0 & 358.0 & 48.0 & 9.5 \\
\hline 1953 & 3,192 & 76.4 & 398.9 & 322.0 & 360.0 & 38.0 & 10.5 \\
\hline 1954 & 2,675 & 66.1 & 411.8 & 322.0 & 370.0 & 48.0 & 8.6 \\
\hline 1955 & 2,369 & 69.4 & 488.3 & 316.0 & 368.0 & 52.0 & 9.4 \\
\hline 1956 & 3,149 & 87.9 & 465.2 & 324.0 & 380.0 & 56.0 & 8.3 \\
\hline 1957 & 2,517 & 70.2 & 464.8 & 324.0 & 385.0 & 61.0 & 7.6 \\
\hline 1958 & 2,562 & 69.5 & 452.1 & 323.0 & 386.0 & 63.0 & 7.2 \\
\hline 1959 & 2,931 & 74.6 & 424.2 & 326.0 & 395.0 & 69.0 & 6.1 \\
\hline 1960 & 3,591 & 82.5 & 382.9 & 335.0 & 407.0 & 72.0 & 5.3 \\
\hline 1961 & 3,612 & 79.9 & 368.7 & 343.0 & 414.0 & 71.0 & 5.2 \\
\hline 1962 & 4,057 & 83.7 & 343.9 & 348.0 & 418.0 & 70.0 & 4.9 \\
\hline 1963 & 4,555 & 86.7 & 317.2 & 352.0 & 422.0 & 70.0 & 4.5 \\
\hline 1964 & 4,487 & 78.6 & 292.0 & 355.0 & 424.0 & 69.0 & 4.2 \\
\hline 1965 & 3,498 & 65.6 & 312.6 & 350.0 & 419.0 & 69.0 & 4.5 \\
\hline 1966 & 3,991 & 73.7 & 307.8 & 353.0 & 420.0 & 67.0 & 4.6 \\
\hline 1967 & 2,752 & 52.9 & 320.4 & 344.0 & 418.0 & 74.0 & 4.3 \\
\hline 1968 & 3,086 & 56.5 & 305.1 & 341.0 & 418.0 & 77.0 & 4.0 \\
\hline 1969 & 2,672 & 50.8 & 316.9 & 338.0 & 417.0 & 79.0 & 4.0 \\
\hline 1970 & 2,736 & 55.4 & 337.5 & 336.0 & 419.0 & 83.0 & 4.1 \\
\hline 1971 & 3,337 & 64.2 & 320.6 & 342.0 & 423.0 & 81.0 & 4.0 \\
\hline 1972 & 2,838 & 50.9 & 298.9 & 341.0 & 421.0 & 80.0 & 3.7 \\
\hline 1973 & 2,843 & 47.3 & 277.3 & 341.0 & 418.0 & 77.0 & 3.6 \\
\hline 1974 & 3,006 & 49.3 & 273.3 & 342.0 & 424.0 & 82.0 & 3.3 \\
\hline 1975 & 2,632 & 43.1 & 272.9 & 341.0 & 428.0 & 87.0 & 3.1 \\
\hline 1976 & 2,971 & 82.6 & 463.4 & 359.0 & 447.0 & 88.0 & 5.3 \\
\hline 1977 & 2,961 & 78.9 & 444.1 & 353.0 & 448.0 & 95.0 & 4.7 \\
\hline 1978 & 2,590 & 66.4 & 427.5 & 345.0 & 443.0 & 98.0 & 4.4 \\
\hline 1979 & 3,014 & 69.0 & 381.0 & 345.0 & 450.0 & 105.0 & 3.6 \\
\hline 1980 & 3,448 & 61.8 & 298.6 & 348.0 & 453.0 & 105.0 & 2.8 \\
\hline 1981 & 4,315 & 66.6 & 257.2 & 357.0 & 467.0 & 110.0 & 2.3 \\
\hline 1982 & 3,550 & 51.0 & 239.0 & 349.0 & 459.0 & 110.0 & 2.2 \\
\hline 1983 & 2,183 & 31.3 & 239.0 & 340.0 & 463.0 & 123.0 & 1.9 \\
\hline 1984 & 1,211 & 19.0 & 267.0 & 355.0 & 475.0 & 120.0 & 2.2 \\
\hline 1985 & 1,587 & 22.1 & 232.0 & 351.0 & 470.0 & 119.0 & 2.0 \\
\hline 1986 & 2,266 & 26.7 & 196.0 & 375.0 & 492.0 & 117.0 & 1.7 \\
\hline 1987 & - & $<0.1$ & - & - & - & - & - \\
\hline 1988 & - & 3.4 & - & - & - & - & - \\
\hline 1989 & - & $<0.1$ & - & - & - & - & - \\
\hline 1990 & - & - & - & - & - & - & - \\
\hline 1991 & - & - & - & - & - & - & - \\
\hline
\end{tabular}

NOTE: Well was completed July 1951; initial water level $280 \mathrm{ft}$; surface elevation $6,139 \mathrm{ft}$. Well was out of service in 1989 due to pumpage of excessive sand. 
Well G-4

\begin{tabular}{|c|c|c|c|c|c|c|c|}
\hline \multirow[b]{2}{*}{ Year } & \multirow{2}{*}{$\begin{array}{c}\text { Pump } \\
\text { Time } \\
\text { (h) }\end{array}$} & \multirow[b]{2}{*}{$\begin{array}{c}\text { Production } \\
\left(1^{6} \text { gal. }\right)\end{array}$} & \multirow{2}{*}{$\begin{array}{c}\text { Pump } \\
\text { Rate } \\
\text { (gpm) }\end{array}$} & \multicolumn{2}{|c|}{ Water Level } & \multirow[b]{2}{*}{$\begin{array}{l}\text { Drawdown } \\
\text { (ft) }\end{array}$} & \multirow{2}{*}{$\begin{array}{c}\text { Specific } \\
\text { Capacity } \\
\text { (gpm/ft) }\end{array}$} \\
\hline & & & & $\begin{array}{l}\text { Nonpumping } \\
\text { (ft) }\end{array}$ & $\begin{array}{l}\text { Pumping } \\
\text { (ft) }\end{array}$ & & \\
\hline$\overline{1951}$ & - & 12.5 & - & 357.0 & 477.0 & 120.0 & - \\
\hline 1952 & 2,401 & 56.9 & 395.0 & 374.0 & 474.0 & 100.0 & 3.9 \\
\hline 1953 & 2,677 & 55.2 & 343.7 & 380.0 & 472.0 & 92.0 & 3.7 \\
\hline 1954 & 2,256 & 58.8 & 434.4 & 383.0 & 526.0 & 143.0 & 3.0 \\
\hline 1955 & 1,172 & 22.7 & 322.8 & 378.0 & 481.0 & 103.0 & 3.1 \\
\hline 1956 & 1,800 & 33.9 & 313.9 & 377.0 & 491.0 & 114.0 & 2.8 \\
\hline 1957 & 1,324 & 24.2 & 304.6 & 373.0 & 498.0 & 125.0 & 2.4 \\
\hline 1958 & 1,970 & 35.9 & 303.7 & 370.0 & 490.0 & 120.0 & 2.5 \\
\hline 1959 & 1,819 & 31.6 & 289.5 & 378.0 & 494.0 & 116.0 & 2.5 \\
\hline 1960 & 2,457 & 37.0 & 251.0 & 385.0 & 509.0 & 124.0 & 2.0 \\
\hline 1961 & 2,787 & 45.0 & 269.1 & 389.0 & 512.0 & 123.0 & 2.2 \\
\hline 1962 & 2,738 & 41.7 & 253.8 & 386.0 & 505.0 & 119.0 & 2.1 \\
\hline 1963 & 3,519 & 46.4 & 219.8 & 388.0 & 504.0 & 116.0 & 1.9 \\
\hline 1964 & 3,561 & 42.9 & 200.8 & 396.0 & 499.0 & 103.0 & 1.9 \\
\hline 1965 & 2,100 & 23.8 & 188.9 & 394.0 & 492.0 & 98.0 & 1.9 \\
\hline 1966 & 2,219 & 33.6 & 252.4 & 391.0 & 498.0 & 107.0 & 2.4 \\
\hline 1967 & 2,690 & 44.8 & 277.6 & 388.0 & 509.0 & 121.0 & 2.3 \\
\hline 1968 & 2,083 & 31.4 & 251.2 & 386.0 & 509.0 & 123.0 & 2.0 \\
\hline 1969 & 1,309 & 17.4 & 221.5 & 387.0 & 505.0 & 118.0 & 1.9 \\
\hline 1970 & 606 & 7.7 & 211.8 & 384.0 & 504.0 & 120.0 & 1.8 \\
\hline 1971 & 1,640 & 21.0 & 213.4 & 389.0 & 503.0 & 114.0 & 1.9 \\
\hline 1972 & 2,840 & 33.3 & 195.4 & 391.0 & 507.0 & 116.0 & 1.7 \\
\hline 1973 & 3,006 & 37.2 & 206.3 & 392.0 & 521.0 & 129.0 & 1.6 \\
\hline 1974 & 2,672 & 34.3 & 213.9 & 392.0 & 519.0 & 127.0 & 1.7 \\
\hline 1975 & 1,977 & 41.0 & 345.6 & 403.0 & 559.0 & 156.0 & 2.2 \\
\hline 1976 & 2,859 & 57.8 & 336.9 & 406.0 & 571.0 & 165.0 & 2.0 \\
\hline 1977 & 2,954 & 62.4 & 352.1 & 406.0 & 589.0 & 183.0 & 1.9 \\
\hline 1978 & 2,607 & 49.5 & 316.5 & 398.0 & 589.0 & 191.0 & 1.7 \\
\hline 1979 & 2,974 & 52.9 & 296.4 & 395.0 & 586.0 & 191.0 & 1.6 \\
\hline 1980 & 2,235 & 35.6 & 265.7 & 394.0 & 580.0 & 186.0 & 1.4 \\
\hline 1981 & 432 & 8.2 & 316.4 & 385.0 & 573.0 & 188.0 & 1.7 \\
\hline 1982 & 3,657 & 65.2 & 297.0 & 386.0 & 578.0 & 192.0 & 1.5 \\
\hline 1983 & 2,604 & 42.2 & 270.0 & - & - & - & - \\
\hline 1984 & 3,766 & 49.7 & 220.0 & - & - & - & - \\
\hline 1985 & 1,747 & 21.7 & 207.0 & 402.0 & 572.0 & 170.0 & 1.2 \\
\hline 1986 & 2,678 & 33.9 & 211.0 & 396.0 & 574.0 & 178.0 & 1.2 \\
\hline 1987 & 2,011 & 25.1 & 208.0 & 398.0 & 573.0 & 175.0 & 1.2 \\
\hline 1988 & 301 & 4.1 & 227.0 & 390.0 & 545.0 & 155.0 & 1.4 \\
\hline 1989 & 1,739 & 21.6 & 207.0 & 401.0 & 562.0 & 161.0 & 1.3 \\
\hline 1990 & 1,539 & 16.8 & 182.0 & 381.0 & 564.0 & 183.0 & 1.0 \\
\hline 1991 & 1,254 & 13.7 & 181.0 & 382.0 & 559.0 & 177.0 & 1.0 \\
\hline 1992 & 1,116 & 12.0 & 179.0 & 387.0 & 544.0 & 157.0 & 1.1 \\
\hline 1993 & - & - & - & 374.0 & - & - & - \\
\hline
\end{tabular}

NOTE: Well was completed May 1951; initial water level $347 \mathrm{ft}$; surface elevation 6,229 ft. 


\section{Well G-5}

\begin{tabular}{|c|c|c|c|c|c|c|c|}
\hline \multirow[b]{2}{*}{ Year } & \multirow[b]{2}{*}{$\begin{array}{c}\text { Pump } \\
\text { Time } \\
\text { (h) }\end{array}$} & \multirow[b]{2}{*}{$\begin{array}{l}\text { Production } \\
\left(10^{6} \text { gal. }\right)\end{array}$} & \multirow[b]{2}{*}{$\begin{array}{c}\text { Pump } \\
\text { Rate } \\
\text { (gpm) }\end{array}$} & \multicolumn{2}{|c|}{ Water Level } & \multirow[b]{2}{*}{$\begin{array}{l}\text { Drawdown } \\
\text { (ft) }\end{array}$} & \multirow[b]{2}{*}{$\begin{array}{r}\text { Specific } \\
\text { Capacity } \\
(\mathrm{gpm} / \mathrm{ft})\end{array}$} \\
\hline & & & & $\begin{array}{c}\text { Nonpumping } \\
\text { (ft) }\end{array}$ & $\begin{array}{c}\text { Pumping } \\
\text { (ft) }\end{array}$ & & \\
\hline$\overline{1951}$ & - & 6.7 & - & 414.0 & - & - & - \\
\hline 1952 & 2,579 & 73.8 & 476.9 & 422.0 & 480.0 & 58.0 & 8.2 \\
\hline 1953 & 1,433 & 37.8 & 439.6 & 425.0 & 467.0 & 42.0 & 10.5 \\
\hline 1954 & 2,617 & 80.9 & 515.2 & 429.0 & 473.0 & 44.0 & 11.7 \\
\hline 1955 & 2,529 & 80.4 & 529.9 & 427.0 & 472.0 & 45.0 & 11.8 \\
\hline 1956 & 3,052 & 97.0 & 529.7 & 431.0 & 478.0 & 47.0 & 11.3 \\
\hline 1957 & 2,385 & 64.1 & 447.9 & 424.0 & 466.0 & 42.0 & 10.7 \\
\hline 1958 & 1,523 & 49.1 & 537.3 & 428.0 & 477.0 & 49.0 & 11.0 \\
\hline 1959 & 2,917 & 101.7 & 581.1 & 435.0 & 495.0 & 60.0 & 9.7 \\
\hline 1960 & 2,828 & 98.0 & 577.6 & 437.0 & 501.0 & 64.0 & 9.0 \\
\hline 1961 & 3,908 & 134.0 & 571.5 & 438.0 & 507.0 & 69.0 & 8.3 \\
\hline 1962 & 4,186 & 142.0 & 565.4 & 440.0 & 511.0 & 71.0 & 8.0 \\
\hline 1963 & 4,528 & 151.0 & 555.8 & 441.0 & 513.0 & 72.0 & 7.7 \\
\hline 1964 & 4,532 & 150.4 & 553.1 & 446.0 & 516.0 & 70.0 & 7.9 \\
\hline 1965 & 3,520 & 117.1 & 554.5 & 443.0 & 516.0 & 73.0 & 7.6 \\
\hline 1966 & 2,555 & 83.2 & 542.7 & 445.0 & 520.0 & 75.0 & 7.2 \\
\hline 1967 & 2,405 & 80.0 & 554.4 & 444.0 & 519.0 & 75.0 & 7.4 \\
\hline 1968 & 2,513 & 81.2 & 538.5 & 443.0 & 517.0 & 74.0 & 7.3 \\
\hline 1969 & 2,649 & 83.3 & 524.1 & 450.0 & 520.0 & 70.0 & 7.5 \\
\hline 1970 & 2,771 & 88.9 & 534.7 & 453.0 & 521.0 & 68.0 & 7.9 \\
\hline 1971 & 2,657 & 88.3 & 553.9 & 450.0 & 521.0 & 71.0 & 7.8 \\
\hline 1972 & 2,902 & 92.4 & 530.7 & 441.0 & 514.0 & 73.0 & 7.3 \\
\hline 1973 & 3,003 & 97.5 & 541.1 & 444.0 & 515.0 & 71.0 & 7.6 \\
\hline 1974 & 2,054 & 69.0 & 559.9 & 440.0 & 513.0 & 73.0 & 7.7 \\
\hline 1975 & 2,266 & 74.7 & 549.4 & 433.0 & 500.0 & 67.0 & 8.2 \\
\hline 1976 & 2,955 & 95.0 & 535.8 & 442.0 & 504.0 & 62.0 & 8.6 \\
\hline 1977 & 2,836 & 92.1 & 541.3 & 444.0 & 504.0 & 60.0 & 9.0 \\
\hline 1978 & 2,608 & 84.2 & 538.4 & 442.0 & 502.0 & 60.0 & 9.0 \\
\hline 1979 & 2,766 & 86.5 & 521.5 & 442.0 & 502.0 & 60.0 & 8.7 \\
\hline 1980 & 2,896 & 89.0 & 512.4 & 442.0 & 502.0 & 60.0 & 8.5 \\
\hline 1981 & 2,124 & 66.7 & 523.4 & 451.0 & 528.0 & 77.0 & 6.8 \\
\hline 1982 & 1,219 & 38.2 & 522.0 & 455.0 & 510.0 & 55.0 & 9.5 \\
\hline 1983 & 2,904 & 73.2 & 420.0 & 445.0 & 492.0 & 47.0 & 8.9 \\
\hline 1984 & 3,838 & 115.4 & 501.0 & 452.0 & 507.0 & 55.0 & 9.4 \\
\hline 1985 & 2,193 & 67.9 & 516.0 & 453.0 & 509.0 & 56.0 & 9.2 \\
\hline 1986 & 2,219 & 52.5 & 394.0 & 453.0 & 494.0 & 41.0 & 9.6 \\
\hline 1987 & 5,732 & 116.7 & 379.0 & 462.0 & 504.0 & 42.0 & 9.0 \\
\hline 1988 & 4,841 & 115.3 & 396.0 & 466.0 & 507.0 & 41.0 & 9.7 \\
\hline 1989 & 4,715 & 110.9 & 392.0 & 474.0 & 514.0 & 40.0 & 9.8 \\
\hline 1990 & 5,094 & 119.2 & 390.0 & 485.0 & 526.0 & 41.0 & 9.5 \\
\hline 1991 & 4,981 & 113.0 & 378.0 & 487.0 & 534.0 & 47.0 & 8.0 \\
\hline 1992 & 5,006 & 114.4 & 376.0 & 470.0 & 508.0 & 38.0 & 9.9 \\
\hline 1993 & 3,859 & 92.2 & 398.0 & 466.0 & 503.0 & 37.0 & 10.8 \\
\hline
\end{tabular}

NOTE: Well was completed May 1951; initial water level $411 \mathrm{ft}$; surface elevation 6,306 ft. 
Well G-6

\begin{tabular}{|c|c|c|c|c|c|c|c|}
\hline \multirow[b]{2}{*}{ Year } & \multirow[b]{2}{*}{$\begin{array}{l}\text { Pump } \\
\text { Time } \\
\text { (h) }\end{array}$} & \multirow[b]{2}{*}{$\begin{array}{c}\text { Production } \\
\left(10^{6} \text { gal. }\right)\end{array}$} & \multirow[b]{2}{*}{$\begin{array}{c}\text { Pump } \\
\text { Rate } \\
\text { (gpm) }\end{array}$} & \multicolumn{2}{|c|}{ Water Level } & \multirow[b]{2}{*}{$\begin{array}{l}\text { Drawdown } \\
\text { (ft) }\end{array}$} & \multirow[b]{2}{*}{$\begin{array}{l}\text { Specific } \\
\text { Capacity } \\
\text { (gpm/ft) }\end{array}$} \\
\hline & & & & $\begin{array}{l}\text { Nonpumping } \\
\text { (ft) }\end{array}$ & $\begin{array}{c}\text { Pumping } \\
\text { (ft) }\end{array}$ & & \\
\hline 1964 & 1,912 & 45.0 & 392.3 & 581.0 & 659.0 & 78.0 & 5.0 \\
\hline 1965 & 3,200 & 74.9 & 390.1 & 582.0 & 660.0 & 78.0 & 5.0 \\
\hline 1966 & 3,931 & 92.2 & 390.9 & 585.0 & 658.0 & 73.0 & 5.4 \\
\hline 1967 & 2,454 & 57.8 & 392.6 & 580.0 & 653.0 & 73.0 & 5.4 \\
\hline 1968 & 2,597 & 56.2 & 360.7 & 574.0 & 647.0 & 73.0 & 4.9 \\
\hline 1969 & 2,698 & 55.6 & 343.5 & 568.0 & 636.0 & 68.0 & 5.1 \\
\hline 1970 & 2,765 & 51.0 & 307.4 & 569.0 & 634.0 & 65.0 & 4.7 \\
\hline 1971 & 2,932 & 42.8 & 243.3 & 573.0 & 629.0 & 56.0 & 4.3 \\
\hline 1972 & 2,516 & 57.0 & 377.6 & 578.0 & 670.0 & 92.0 & 4.1 \\
\hline 1973 & 2,991 & 65.3 & 363.9 & 579.0 & 667.0 & 88.0 & 4.1 \\
\hline 1974 & 2,950 & 63.8 & 360.5 & 579.0 & 665.0 & 86.0 & 4.2 \\
\hline 1975 & 2,717 & 56.7 & 347.8 & 577.0 & 659.0 & 82.0 & 4.2 \\
\hline 1976 & 2,966 & 57.8 & 324.8 & 584.0 & 662.0 & 78.0 & 4.2 \\
\hline 1977 & 2,954 & 54.4 & 306.9 & 586.0 & 659.0 & 73.0 & 4.2 \\
\hline 1978 & 2,218 & 38.4 & 288.9 & 581.0 & 645.0 & 64.0 & 4.5 \\
\hline 1979 & 1,030 & 18.2 & 295.1 & 579.0 & 645.0 & 66.0 & 4.8 \\
\hline 1980 & 1,789 & 34.5 & 321.5 & 583.0 & 670.0 & 87.0 & 3.7 \\
\hline 1981 & 4,302 & 76.5 & 296.4 & 586.0 & 673.0 & 87.0 & 3.4 \\
\hline 1982 & 3,763 & 63.6 & 281.0 & 588.0 & 669.0 & 81.0 & 3.5 \\
\hline 1983 & 1,960 & 35.4 & 301.0 & 582.0 & 668.0 & 86.0 & 3.5 \\
\hline 1984 & 3,010 & 55.3 & 306.0 & 589.0 & 666.0 & 77.0 & 3.9 \\
\hline 1985 & 3,980 & 71.4 & 299.0 & 586.0 & 664.0 & 78.0 & 3.8 \\
\hline 1986 & 4,420 & 76.7 & 293.0 & 576.0 & 654.0 & 78.0 & 3.8 \\
\hline 1987 & 5,100 & 81.4 & 266.0 & 595.0 & 671.0 & 76.0 & 3.5 \\
\hline 1988 & 5,121 & 82.1 & 267.0 & 591.0 & 669.0 & 78.0 & 3.4 \\
\hline 1989 & 5,000 & 81.6 & 272.0 & 592.0 & 669.0 & 77.0 & 3.5 \\
\hline 1990 & 5,202 & 84.9 & 272.0 & 589.0 & 670.0 & 81.0 & 3.4 \\
\hline 1991 & 5,063 & 81.2 & 267.0 & 591.0 & 674.0 & 83.0 & 3.2 \\
\hline 1992 & 4,382 & 70.2 & 268.0 & 591.0 & 673.0 & 82.0 & 3.3 \\
\hline 1993 & - & - & - & 575.0 & - & - & - \\
\hline
\end{tabular}

NOTE: Well was completed March 1964; initial water level $572 \mathrm{ft}$; surface elevation 6,422 ft. 


\section{Well PM-1}

\begin{tabular}{|c|c|c|c|c|c|c|c|}
\hline \multirow[b]{2}{*}{ Year } & \multirow{2}{*}{$\begin{array}{c}\text { Pump } \\
\text { Time } \\
\text { (h) }\end{array}$} & \multirow[b]{2}{*}{$\begin{array}{c}\text { Production } \\
\left(10^{6} \text { gal. }\right)\end{array}$} & \multirow[b]{2}{*}{$\begin{array}{c}\text { Pump } \\
\text { Rate } \\
\text { (gpm) }\end{array}$} & \multicolumn{2}{|c|}{ Water Level } & \multirow[b]{2}{*}{$\begin{array}{l}\text { Drawdown } \\
\text { (ft) }\end{array}$} & \multirow[b]{2}{*}{$\begin{array}{r}\text { Specific } \\
\text { Capacity } \\
\text { (gpm/ft) }\end{array}$} \\
\hline & & & & $\begin{array}{l}\text { Nonpumping } \\
\text { (ft) }\end{array}$ & $\begin{array}{l}\text { Pumping } \\
\text { (ft) }\end{array}$ & & \\
\hline$\overline{1965}$ & 2,754 & 99.2 & 600.3 & 746.0 & 786.0 & 40.0 & 15.0 \\
\hline 1966 & 3,086 & 108.0 & 583.3 & 740.0 & 779.0 & 39.0 & 15.0 \\
\hline 1967 & 2,870 & 111.0 & 644.6 & 737.0 & 781.0 & 44.0 & 14.6 \\
\hline 1968 & 1,846 & 68.1 & 614.8 & 735.0 & 769.0 & 34.0 & 18.1 \\
\hline 1969 & 951 & 34.4 & 602.9 & 733.0 & 766.0 & 33.0 & 18.3 \\
\hline 1970 & 1,781 & 66.2 & 619.5 & 733.0 & 769.0 & 36.0 & 17.2 \\
\hline 1971 & 2,728 & 101.0 & 617.1 & 733.0 & 766.0 & 33.0 & 18.7 \\
\hline 1972 & 2,415 & 84.9 & 585.9 & 735.0 & 762.0 & 27.0 & 21.7 \\
\hline 1973 & 1,688 & 46.5 & 459.1 & 736.0 & 755.0 & 19.0 & 24.2 \\
\hline 1974 & 2,649 & 96.3 & 605.9 & 740.0 & 768.0 & 28.0 & 21.6 \\
\hline 1975 & 2,567 & 94.8 & 615.5 & 741.0 & 766.0 & 25.0 & 24.6 \\
\hline 1976 & 2,933 & 106.8 & 606.9 & 744.0 & 767.0 & 23.0 & 26.4 \\
\hline 1977 & 2,969 & 105.4 & 591.7 & 745.0 & 767.0 & 22.0 & 26.9 \\
\hline 1978 & 2,544 & 90.6 & 593.3 & 745.0 & 767.0 & 22.0 & 27.0 \\
\hline 1979 & 2,350 & 83.4 & 591.5 & 744.0 & 766.0 & 22.0 & 26.9 \\
\hline 1980 & 2,786 & 98.5 & 588.6 & 746.0 & 769.0 & 23.0 & 25.7 \\
\hline 1981 & 2,789 & 98.5 & 588.6 & 747.0 & 769.0 & 22.0 & 26.8 \\
\hline 1982 & 2,820 & 99.6 & 589.0 & 748.0 & 770.0 & 22.0 & 26.8 \\
\hline 1983 & 2,464 & 86.5 & 585.0 & 747.0 & 769.0 & 22.0 & 26.6 \\
\hline 1984 & 2,667 & 92.8 & 580.0 & 749.0 & 772.0 & 23.0 & 25.6 \\
\hline 1985 & 2,760 & 95.4 & 576.0 & 749.0 & 770.0 & 21.0 & 27.4 \\
\hline 1986 & 2,130 & 73.9 & 578.0 & 748.0 & 770.0 & 22.0 & 26.3 \\
\hline 1987 & 2,912 & 102.4 & 586.0 & 752.0 & 773.0 & 21.0 & 27.9 \\
\hline 1988 & 2,758 & 98.0 & 592.0 & 751.0 & 775.0 & 24.0 & 24.7 \\
\hline 1989 & 3,014 & 104.9 & 580.0 & 752.0 & 774.0 & 22.0 & 26.4 \\
\hline 1990 & 2,620 & 88.2 & 561.0 & 752.0 & 772.0 & 20.0 & 28.0 \\
\hline 1991 & 2,600 & 88.6 & 568.0 & 752.0 & 774.0 & 22.0 & 25.8 \\
\hline 1992 & 2,503 & 92.7 & 617.0 & 756.0 & 780.0 & 24.0 & 25.7 \\
\hline 1993 & 1,802 & 63.9 & 591.0 & 758.0 & 779.0 & 21.0 & 28.1 \\
\hline
\end{tabular}

NOTE: Well was completed March 1965; initial water level $722.1 \mathrm{ft}$; surface elevation $6,520 \mathrm{ft}$. 


\section{Well PM-2}

\begin{tabular}{|c|c|c|c|c|c|c|c|}
\hline \multirow[b]{2}{*}{ Year } & \multirow{2}{*}{$\begin{array}{l}\text { Pump } \\
\text { Time } \\
\text { (h) }\end{array}$} & \multirow[b]{2}{*}{$\begin{array}{l}\text { Production } \\
\left(10^{6} \text { gal. }\right)\end{array}$} & \multirow{2}{*}{$\begin{array}{c}\text { Pump } \\
\text { Rate } \\
\text { (gpm) }\end{array}$} & \multicolumn{2}{|c|}{ Water Level } & \multirow[b]{2}{*}{$\begin{array}{l}\text { Drawdown } \\
\text { (ft) }\end{array}$} & \multirow{2}{*}{$\begin{array}{l}\text { Specific } \\
\text { Capacity } \\
\text { (gpm/ft) }\end{array}$} \\
\hline & & & & $\begin{array}{c}\text { Nonpumping } \\
\text { (ft) }\end{array}$ & $\begin{array}{c}\text { Pumping } \\
\text { (ft) }\end{array}$ & & \\
\hline 1966 & 221 & 18.9 & $1,425.3$ & 826.0 & 889.0 & 63.0 & 22.6 \\
\hline 1967 & 4,336 & 370.0 & $1,422.2$ & 834.0 & 888.0 & 54.0 & 26.3 \\
\hline 1968 & 3,865 & 328.2 & $1,415.3$ & 838.0 & 889.0 & 51.0 & 27.8 \\
\hline 1969 & 3,304 & 279.9 & $1,411.9$ & 838.0 & 890.0 & 52.0 & 27.2 \\
\hline 1970 & 3,529 & 300.6 & $1,419.7$ & 839.0 & 893.0 & 54.0 & 26.3 \\
\hline 1971 & 4,035 & 339.5 & $1,402.3$ & 841.0 & 898.0 & 57.0 & 24.6 \\
\hline 1972 & 4,611 & 385.3 & $1,392.7$ & 845.0 & 902.0 & 57.0 & 24.4 \\
\hline 1973 & 4,571 & 380.6 & $1,387.7$ & 849.0 & 907.0 & 58.0 & 23.9 \\
\hline 1974 & 5,443 & 450.9 & $1,380.7$ & 853.0 & 912.0 & 59.0 & 23.4 \\
\hline 1975 & 4,644 & 385.3 & $1,382.8$ & 854.0 & 913.0 & 59.0 & 23.4 \\
\hline 1976 & 5,382 & 442.0 & $1,368.8$ & 866.0 & 924.0 & 58.0 & 23.6 \\
\hline 1977 & 3,306 & 272.8 & $1,375.3$ & 868.0 & 924.0 & 56.0 & 24.6 \\
\hline 1978 & 4,743 & 388.4 & $1,364.9$ & 871.0 & 928.0 & 57.0 & 23.9 \\
\hline 1979 & 4,671 & 381.8 & $1,262.2$ & 872.0 & 924.0 & 52.0 & 26.2 \\
\hline 1980 & 5,023 & 409.6 & $1,359.2$ & 873.0 & 931.0 & 58.0 & 23.4 \\
\hline 1981 & 4,551 & 370.1 & $1,355.4$ & 876.0 & 934.0 & 58.0 & 23.4 \\
\hline 1982 & 4,319 & 359.3 & $1,386.0$ & 874.0 & 934.0 & 60.0 & 23.1 \\
\hline 1983 & 1,922 & 157.9 & $1,369.0$ & 876.0 & 935.0 & 59.0 & 23.2 \\
\hline 1984 & 996 & 81.6 & $1,365.0$ & 866.0 & 930.0 & 64.0 & 21.7 \\
\hline 1985 & 1,749 & 143.3 & $1,365.0$ & 851.0 & 916.0 & 65.0 & 21.0 \\
\hline 1986 & 1,036 & 84.4 & $1,359.0$ & 851.0 & 915.0 & 64.0 & 21.2 \\
\hline 1987 & 351 & 28.3 & $1,340.0$ & 851.0 & 907.0 & 56.0 & 23.9 \\
\hline 1988 & 1,843 & 146.8 & $1,328.0$ & 869.0 & 931.0 & 62.0 & 21.4 \\
\hline 1989 & 1,639 & 130.0 & $1,322.0$ & 860.0 & 920.0 & 60.0 & 22.0 \\
\hline 1990 & 3,164 & 250.4 & $1,319.0$ & 860.0 & 928.0 & 68.0 & 19.4 \\
\hline 1991 & 2,141 & 170.7 & $1,329.0$ & 855.0 & 918.0 & 63.0 & 21.1 \\
\hline 1992 & 3,486 & 277.7 & $1,328.0$ & 860.0 & 929.0 & 69.0 & 19.2 \\
\hline 1993 & 3,420 & 267.8 & $1,305.0$ & 855.0 & 924.0 & 69.0 & 18.9 \\
\hline
\end{tabular}

NOTE: Well was completed July 1965; initial water level $823 \mathrm{ft}$; surface elevation $6,715 \mathrm{ft}$. 
Well PM-3

\begin{tabular}{|c|c|c|c|c|c|c|c|}
\hline \multirow[b]{2}{*}{ Year } & \multirow[b]{2}{*}{$\begin{array}{c}\text { Pump } \\
\text { Time } \\
\text { (h) }\end{array}$} & \multirow[b]{2}{*}{$\begin{array}{l}\text { Production } \\
\left(10^{6} \text { gal. }\right)\end{array}$} & \multirow[b]{2}{*}{$\begin{array}{c}\text { Pump } \\
\text { Rate } \\
\text { (gpm) }\end{array}$} & \multicolumn{2}{|c|}{ Water Level } & \multirow[b]{2}{*}{$\begin{array}{l}\text { Drawdown } \\
\text { (ft) }\end{array}$} & \multirow[b]{2}{*}{$\begin{array}{l}\text { Specific } \\
\text { Capacity } \\
\text { (gpm/ft) }\end{array}$} \\
\hline & & & & $\begin{array}{c}\text { Nonpumping } \\
\text { (ft) }\end{array}$ & $\begin{array}{l}\text { Pumping } \\
\text { (ft) }\end{array}$ & & \\
\hline 1968 & 2,327 & 187.4 & $1,342.2$ & 743.0 & 771.0 & 28.0 & 47.9 \\
\hline 1969 & 3,241 & 254.7 & $1,309.8$ & 746.0 & 772.0 & 26.0 & 50.4 \\
\hline 1970 & 2,905 & 227.8 & $1,306.9$ & 750.0 & 774.0 & 24.0 & 54.5 \\
\hline 1971 & 2,774 & 216.3 & $1,299.6$ & 751.0 & 774.0 & 23.0 & 56.5 \\
\hline 1972 & 2,445 & 192.1 & $1,309.5$ & 752.0 & 775.0 & 23.0 & 56.9 \\
\hline 1973 & 3,256 & 257.8 & $1,319.6$ & 755.0 & 778.0 & 23.0 & 57.4 \\
\hline 1974 & 3,241 & 255.3 & $1,312.9$ & 756.0 & 779.0 & 23.0 & 57.1 \\
\hline 1975 & 3,421 & 269.3 & $1,312.0$ & 757.0 & 780.0 & 23.0 & 57.0 \\
\hline 1976 & 3,171 & 268.3 & $1,410.2$ & 758.0 & 784.0 & 26.0 & 54.2 \\
\hline 1977 & 2,792 & 235.5 & $1,405.8$ & 758.0 & 784.0 & 26.0 & 54.1 \\
\hline 1978 & 2,516 & 211.0 & $1,397.6$ & 759.0 & 784.0 & 25.0 & 55.9 \\
\hline 1979 & 2,359 & 197.2 & $1,393.0$ & 760.0 & 784.0 & 24.0 & 58.0 \\
\hline 1980 & 2,796 & 234.4 & $1,397.2$ & 760.0 & 785.0 & 25.0 & 55.9 \\
\hline 1981 & 2,784 & 232.4 & $1,391.3$ & 761.0 & 786.0 & 25.0 & 55.6 \\
\hline 1982 & 2,831 & 238.1 & $1,402.0$ & 762.0 & 785.0 & 23.0 & 60.9 \\
\hline 1983 & 2,496 & 207.6 & $1,386.0$ & 762.0 & 785.0 & 23.0 & 60.3 \\
\hline 1984 & 3,317 & 275.6 & $1,385.0$ & 762.0 & 787.0 & 25.0 & 55.4 \\
\hline 1985 & 2,643 & 221.2 & $1,395.0$ & 762.0 & 784.0 & 22.0 & 63.4 \\
\hline 1986 & 2,920 & 244.8 & $1,397.0$ & 763.0 & 787.0 & 24.0 & 58.2 \\
\hline 1987 & 2,984 & 250.2 & $1,397.0$ & 763.0 & 788.0 & 25.0 & 55.9 \\
\hline 1988 & 2,766 & 232.0 & $1,397.0$ & 764.0 & 788.0 & 24.0 & 58.2 \\
\hline 1989 & 2,656 & 221.0 & $1,386.0$ & 765.0 & 791.0 & 26.0 & 53.3 \\
\hline 1990 & 2,949 & 244.6 & $1,382.0$ & 767.0 & 790.0 & 23.0 & 60.0 \\
\hline 1991 & 2,752 & 229.5 & $1,385.0$ & 768.0 & 791.0 & 23.0 & 60.2 \\
\hline 1992 & 3,610 & 307.4 & $1,419.0$ & 770.0 & 794.0 & 24.0 & 59.1 \\
\hline 1993 & 2,018 & 168.5 & $1,391.0$ & 771.0 & 797.0 & 26.0 & 53.5 \\
\hline
\end{tabular}

NOTE: Well was completed November 1966; initial water level $740 \mathrm{ft}$; surface elevation $6,640 \mathrm{ft}$. 


\section{Well PM-4}

\begin{tabular}{|c|c|c|c|c|c|c|c|}
\hline \multirow[b]{2}{*}{ Year } & \multirow{2}{*}{$\begin{array}{c}\text { Pump } \\
\text { Time } \\
\text { (h) }\end{array}$} & \multirow[b]{2}{*}{$\begin{array}{l}\text { Production } \\
\left(1^{6} \text { gal. }\right)\end{array}$} & \multirow{2}{*}{$\begin{array}{c}\text { Pump } \\
\text { Rate } \\
\text { (gpm) }\end{array}$} & \multicolumn{2}{|c|}{ Water Level } & \multirow[b]{2}{*}{$\begin{array}{l}\text { Drawdown } \\
\text { (ft) }\end{array}$} & \multirow[b]{2}{*}{$\begin{array}{l}\text { Specific } \\
\text { Capacity } \\
\text { (gpm/ft) }\end{array}$} \\
\hline & & & & $\begin{array}{c}\text { Nonpumping } \\
\text { (ft) }\end{array}$ & $\begin{array}{l}\text { Pumping } \\
\text { (ft) }\end{array}$ & & \\
\hline 1982 & 869 & 76.2 & 1,460 & 1,050 & 1,091 & 41 & 35.6 \\
\hline 1983 & 5,267 & 452.5 & 1,432 & 1,066 & 1,101 & 35 & 40.9 \\
\hline 1984 & 4,059 & 325.8 & 1,338 & 1,065 & 1,104 & 39 & 34.3 \\
\hline 1985 & 4,759 & 379.2 & 1,328 & 1,066 & 1,101 & 35 & 37.9 \\
\hline 1986 & 3,925 & 307.4 & 1,305 & 1,084 & 1,119 & 35 & 37.3 \\
\hline 1987 & 5,071 & 392.2 & 1,289 & 1,081 & 1,117 & 36 & 35.8 \\
\hline 1988 & 2,435 & 218.7 & 1,313 & 1,079 & 1,117 & 38 & 34.6 \\
\hline 1989 & 5,387 & 418.9 & 1,296 & 1,085 & 1,122 & 37 & 35.0 \\
\hline 1990 & 2,827 & 219.3 & 1,293 & 1,083 & 1,123 & 40 & 32.3 \\
\hline 1991 & 2,832 & 219.5 & 1,292 & 1,081 & 1,123 & 42 & 30.8 \\
\hline 1992 & 2,064 & 158.3 & 1,278 & 1,084 & 1,125 & 41 & 31.2 \\
\hline 1993 & 3,901 & 249.7 & 1,295 & - & - & - & - \\
\hline
\end{tabular}

NOTE: Well was completed August 1981; initial water level $1,060 \mathrm{ft}$; surface elevation $6,920 \mathrm{ft}$.

\section{Well PM-5}

\begin{tabular}{lccccccc} 
Year & $\begin{array}{c}\text { Pump } \\
\text { Time } \\
\text { (h) }\end{array}$ & $\begin{array}{c}\text { Production } \\
\left(\mathbf{1 0}^{6} \text { gal.) }\right.\end{array}$ & $\begin{array}{c}\text { Pump } \\
\text { Rate } \\
\text { (gpm) }\end{array}$ & $\begin{array}{c}\text { Nonpumping } \\
\text { (ft) }\end{array}$ & $\begin{array}{c}\text { Pumping } \\
\text { (ft) }\end{array}$ & $\begin{array}{c}\text { Wrawdown } \\
\text { (ft) }\end{array}$ & $\begin{array}{c}\text { Specific } \\
\text { Capacity } \\
\text { (gpm/ft) }\end{array}$ \\
\hline 1985 & - & 2.0 & - & - & - & - & - \\
1986 & 2,047 & 147.3 & 1,199 & - & - & - & - \\
1987 & 1,620 & 118.6 & 1,220 & 1,237 & 1,345 & 108 & 11.3 \\
1988 & 1,754 & 128.6 & 1,221 & 1,233 & 1,345 & 112 & 10.9 \\
1989 & 1,184 & 86.2 & 1,213 & 1,239 & 1,352 & 113 & 10.7 \\
1990 & 1,611 & 121.0 & 1,252 & 1,234 & 1,347 & 113 & 11.1 \\
1991 & 1,497 & 112.1 & 1,248 & 1,239 & 1,346 & 107 & 11.7 \\
1992 & 2,823 & 208.4 & 1,233 & 1,248 & 1,345 & 97 & 12.7 \\
1993 & 1,709 & 126.0 & 1,229 & 1,224 & 1,321 & 97 & 12.6 \\
\hline
\end{tabular}

NOTE: Well was completed September 1982; initial water level 1,208 ft; surface elevation 7,095 ft.

\section{Well 0-4}

\begin{tabular}{|c|c|c|c|c|c|c|c|}
\hline \multirow[b]{2}{*}{ Year } & \multirow[b]{2}{*}{$\begin{array}{c}\text { Pump } \\
\text { Time } \\
\text { (h) }\end{array}$} & \multirow[b]{2}{*}{$\begin{array}{c}\text { Production } \\
\left(10^{6} \text { gal. }\right)\end{array}$} & \multirow[b]{2}{*}{$\begin{array}{c}\text { Pump } \\
\text { Rate } \\
\text { (gpm) }\end{array}$} & \multicolumn{2}{|c|}{ Water Level } & \multirow[b]{2}{*}{$\begin{array}{l}\text { Drawdown } \\
\text { (ft) }\end{array}$} & \multirow[b]{2}{*}{$\begin{array}{r}\text { Specific } \\
\text { Capacity } \\
(\mathrm{gpm} / \mathrm{ft})\end{array}$} \\
\hline & & & & $\begin{array}{c}\text { Nonpumping } \\
\text { (ft) }\end{array}$ & $\begin{array}{c}\text { Pumping } \\
\text { (ft) }\end{array}$ & & \\
\hline 1993 & 2,942 & 283.8 & 1,603 & 861 & 889 & 28 & 57.3 \\
\hline
\end{tabular}

NOTE: Well was completed March 1990; initial water level $780 \mathrm{ft}$; surface elevation 6,627 ft. 
Water Canyon Gallery

\begin{tabular}{|c|c|c|c|}
\hline Year & $\begin{array}{c}\text { Time } \\
\text { (h) }\end{array}$ & $\begin{array}{c}\text { Production } \\
\left(\mathbf{1 0}^{6} \text { gal. }\right)\end{array}$ & $\begin{array}{c}\text { Discharge } \\
\text { Rate } \\
\text { (gpm) }\end{array}$ \\
\hline 1947 & 8,760 & 84.00 & 159.8 \\
\hline 1948 & 8,784 & 97.00 & 184.0 \\
\hline 1949 & 8,760 & 92.00 & 175.0 \\
\hline 1950 & 8,760 & 54.00 & 102.7 \\
\hline 1951 & 8,760 & 39.00 & 74.2 \\
\hline 1952 & 8,784 & 48.00 & 91.1 \\
\hline 1953 & 8,760 & 39.00 & 74.2 \\
\hline 1954 & 8,760 & 40.00 & 76.1 \\
\hline 1955 & 8,760 & 33.00 & 62.8 \\
\hline 1956 & 8,784 & 23.00 & 43.6 \\
\hline 1957 & 8,760 & 40.00 & 76.1 \\
\hline 1958 & 8,760 & 60.00 & 114.2 \\
\hline 1959 & 8,760 & 54.00 & 102.7 \\
\hline 1960 & 8,784 & 48.00 & 91.1 \\
\hline 1961 & 8,760 & 54.00 & 102.7 \\
\hline 1962 & 8,760 & 67.00 & 127.5 \\
\hline 1963 & 8,760 & 51.00 & 97.0 \\
\hline 1964 & 8,784 & 45.00 & 85.4 \\
\hline 1965 & 8,760 & 72.00 & 137.0 \\
\hline 1966 & 8,760 & 82.00 & 156.0 \\
\hline 1967 & 8,760 & 56.00 & 106.5 \\
\hline 1968 & 8,784 & 65.00 & 123.3 \\
\hline 1969 & 8,760 & 80.00 & 152.2 \\
\hline 1970 & 8,760 & 65.00 & 123.7 \\
\hline 1971 & 8,760 & 37.00 & 70.4 \\
\hline 1972 & 8,784 & 40.00 & 75.9 \\
\hline 1973 & 8,760 & 49.00 & 93.2 \\
\hline 1974 & 8,760 & 35.00 & 66.6 \\
\hline 1975 & 8,760 & 42.00 & 79.9 \\
\hline 1976 & 8,784 & 41.00 & 77.8 \\
\hline 1977 & 8,760 & 57.00 & 108.4 \\
\hline 1978 & 8,760 & 45.00 & 86.2 \\
\hline 1979 & 8,760 & 44.00 & 83.7 \\
\hline 1980 & 8,784 & 32.00 & 60.7 \\
\hline 1981 & 8,760 & 45.50 & 86.6 \\
\hline 1982 & 8,760 & 45.90 & 94.9 \\
\hline 1983 & 8,760 & 38.20 & 72.7 \\
\hline 1984 & 8,784 & 34.00 & 65.4 \\
\hline 1985 & 8,760 & 36.60 & 69.6 \\
\hline 1986 & 8,760 & 28.20 & 53.6 \\
\hline 1987 & 8,760 & 34.20 & 65.1 \\
\hline 1988 & 8,784 & 34.50 & 65.5 \\
\hline 1989 & 8,760 & 23.00 & 43.8 \\
\hline 1990 & 8,760 & $9.30^{\mathrm{a}}$ & - \\
\hline 1991 & - & $12.00^{a}$ & - \\
\hline 1992 & - & $0.12^{\mathrm{a}}$ & - \\
\hline 1993 & - & 6.4 & - \\
\hline
\end{tabular}

aIndustrial use, the rest released as Water Canyon surface drainage. 
Water Levels in Main Aquifer Test Wells

\begin{tabular}{|c|c|c|c|c|c|c|c|c|}
\hline Well & TW-1 & TW-2 & TW-3 & TW-4 & TW-8 & DT-5A & DT-9 & DT-10 \\
\hline \multicolumn{9}{|c|}{ Completion Information } \\
\hline $\begin{array}{l}\text { Surface (ft) } \\
\text { Elevation (f }\end{array}$ & $6,369.19$ & $6,647.63$ & $6,595.31$ & $7,244.56$ & $6,877.62$ & $7,143.86$ & $6,936.71$ & $7,019.92$ \\
\hline $\begin{array}{l}\text { Initial } \\
\text { Water Leve }\end{array}$ & 584.90 & 758.90 & 743.30 & $1,170.80$ & 968.00 & $1,173.00$ & $1,003.00$ & 1,085 \\
\hline Date & $1 / 1950$ & $11 / 1949$ & $11 / 1949$ & $3 / 1950$ & $12 / 1960$ & $12 / 1959$ & $2 / 1960$ & $3 / 1960$ \\
\hline Well & TW-1 & TW-2 & TW-3 & TW-4 & TW-8 & DT-5A & DT-9 & DT-10 \\
\hline
\end{tabular}

\section{Static Water Levels (ft below surface) \\ Year}

1949

1950

1951

1952

1953

1954

1955

1956

1957

1958

1959

1960

1961

1962

1963

1964

1965

1966

1967

1968

1969

1970

1971

1972

1973

1974

1975

1976

1977

1978

1979

1980

1981

1982

1983

1984

1985

1986

1987

1988

775.5

787

\begin{tabular}{|c|c|c|c|c|c|c|c|}
\hline & 758.9 & 743.3 & & & & & \\
\hline 584.9 & & & $1,170.8$ & & & & \\
\hline 592.31 & 760.09 & 750.87 & $1,166.08$ & & & & \\
\hline 591.38 & & 750.98 & $1,166.62$ & & & & \\
\hline 591.2 & 759.91 & 751.37 & $1,167.51$ & & & & \\
\hline \multirow[t]{2}{*}{591.81} & 760.6 & 751.36 & $1,166.2$ & & & . & \\
\hline & 760.25 & 751.27 & & & & & \\
\hline 592 & 759.93 & 750.87 & & & & & \\
\hline 593.1 & 759.88 & 751.33 & & & & & \\
\hline 593.82 & 759.68 & 751.68 & & & & & \\
\hline 593.92 & & 751.77 & & & & & \\
\hline 593.36 & 760.53 & 751.75 & $1,165.86$ & 968 & $1,173.16$ & $1,003.29$ & $1,090.65$ \\
\hline 591.8 & 760.85 & & $1,165.93$ & & & $1,003.4$ & $1,090.58$ \\
\hline 589.96 & 761.19 & 751.8 & & & & 1,004 & \\
\hline 588.26 & 762.85 & 753.62 & & 968.72 & $1,176.92$ & $1,004.6$ & $1,090.34$ \\
\hline 587.85 & & 754.21 & & 968.7 & $1,176.98$ & 1,005 & $1,090.4$ \\
\hline \multirow[t]{4}{*}{588.38} & & & & 968.7 & & $1,005.1$ & $1,090.47$ \\
\hline & & & & & & $1,005.2$ & $1,090.57$ \\
\hline & & & & & & $1,005.4$ & $1,090.59$ \\
\hline & & & & & & $1,005.5$ & \\
\hline
\end{tabular}

$1,005.5$

$1,005.2$

$1,005.3$

$1,005.6$

$1,005.6$

$1,005.8$

$1,006.1$

$1,006.2$

$1,006.4$

$1,006.2$

$1,006.2$

$1,006.2$ 
Water Levels in Main Aquifer Test Wells (Cont.)

\begin{tabular}{|c|c|c|c|c|c|c|c|c|}
\hline Well & TW-1 & TW-2 & TW-3 & $T W-4$ & TW-8 & DT-5A & DT-9 & DT-10 \\
\hline \multicolumn{9}{|c|}{$\begin{array}{l}\text { Decline from Initial Level (ft) } \\
\text { Year }\end{array}$} \\
\hline 1989 & & & & & & & & \\
\hline 1990 & 508.37 & 787.2 & 772.0 & & & & & \\
\hline 1991 & 507 & 789 & & & & & & \\
\hline 1992 & 536.5 & 792.52 & 777.5 & & 992.45 & & $1,015.01$ & \\
\hline 1993 & 546.77 & 793.04 & 775.92 & $1,174.52$ & 992.9 & $1,182.58$ & $1,015.96$ & $1,096.92$ \\
\hline \multicolumn{9}{|l|}{1945} \\
\hline \multicolumn{9}{|l|}{1946} \\
\hline \multicolumn{9}{|l|}{1947} \\
\hline \multicolumn{9}{|l|}{1948} \\
\hline 1949 & & 0.00 & 0.00 & & & & & \\
\hline 1950 & 0.00 & & & 0.00 & & & & \\
\hline 1951 & -7.41 & -1.19 & -7.57 & 4.72 & & & & \\
\hline 1952 & -6.48 & & -7.68 & 4.18 & & & & \\
\hline 1953 & -6.30 & -1.01 & -8.07 & 3.29 & & & & \\
\hline 1954 & -6.91 & -1.70 & -8.06 & 4.60 & & & & \\
\hline 1955 & & -1.35 & -7.97 & & & & & \\
\hline 1956 & -7.10 & -1.03 & -7.57 & & & & & \\
\hline 1957 & -8.20 & -0.98 & -8.03 & & & & & \\
\hline 1958 & -8.92 & -0.78 & -8.38 & & & & & \\
\hline 1959 & -9.02 & & -8.47 & & & & & \\
\hline 1960 & -8.46 & -1.63 & -8.45 & 4.94 & 0.00 & -0.16 & -0.29 & -5.65 \\
\hline 1961 & -6.90 & -1.95 & & 4.87 & & & -0.40 & -5.58 \\
\hline 1962 & -5.06 & -2.29 & -8.50 & & & & -1.00 & \\
\hline 1963 & -3.36 & -3.95 & -10.32 & & -0.72 & -3.92 & -1.60 & -5.34 \\
\hline 1964 & -2.95 & & -10.91 & & -0.70 & -3.98 & -2.00 & -5.40 \\
\hline 1965 & -3.48 & & & & -0.70 & & -2.10 & -5.47 \\
\hline 1966 & & & & & & & -2.20 & -5.57 \\
\hline 1967 & & & & & & & -2.40 & -5.59 \\
\hline 1968 & & & & & & & -2.50 & \\
\hline \multicolumn{9}{|l|}{1969} \\
\hline \multicolumn{9}{|l|}{1970} \\
\hline 1971 & & & & & & & -2.50 & \\
\hline 1972 & & & & & & & -2.20 & \\
\hline 1973 & & & & & & & -2.30 & \\
\hline 1974 & & & & & & & -2.60 & \\
\hline 1975 & & & & & & & -2.60 & \\
\hline 1976 & & & & & & & -2.80 & \\
\hline 1977 & & -16.60 & & & & & -3.10 & \\
\hline 1978 & & & & & & & -3.20 & \\
\hline 1979 & & & & & & & -3.40 & \\
\hline 1980 & & & & & & & -3.20 & \\
\hline 1981 & & & & & & & -3.20 & \\
\hline 1982 & & & & & & & -3.20 & \\
\hline \multicolumn{9}{|l|}{1983} \\
\hline \multicolumn{9}{|l|}{1984} \\
\hline \multicolumn{9}{|l|}{1985} \\
\hline \multicolumn{9}{|l|}{1986} \\
\hline \multicolumn{9}{|l|}{1987} \\
\hline 1988 & & -28.10 & & & & & & \\
\hline
\end{tabular}


Water Levels in Main Aquifer Test Wells (Cont.)

\begin{tabular}{|c|c|c|c|c|c|c|c|c|}
\hline Well & TW-1 & TW-2 & TW-3 & TW-4 & TW-8 & DT-5A & DT-9 & DT-10 \\
\hline \multicolumn{9}{|l|}{1989} \\
\hline 1990 & 76.53 & & -28.30 & & & & & \\
\hline 1991 & 77.90 & -30.10 & & & & & & \\
\hline 1992 & 48.40 & -33.62 & -34.20 & & -24.45 & & -12.01 & \\
\hline 1993 & 38.13 & -34.14 & -32.62 & -3.72 & -24.90 & -9.58 & -12.96 & -11.92 \\
\hline
\end{tabular}

